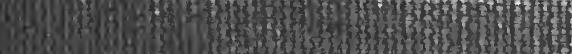

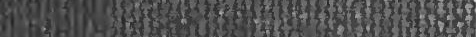
5. II.

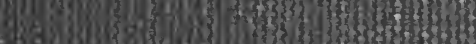
Diingon for.

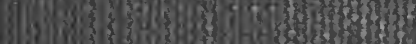

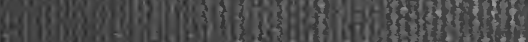

al

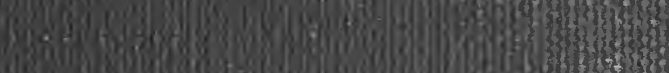
(1) 5. 30.0.

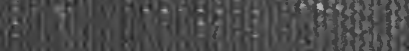
4.8. 323, 8)

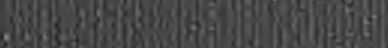
tos? 180 (1) cons. 3.1350 7ind bring

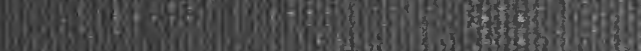

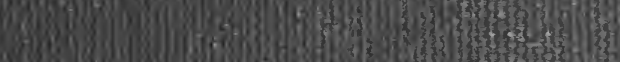
H. tor ch 15.

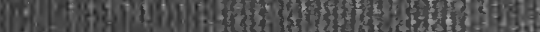

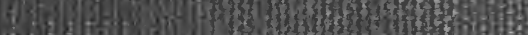
ton

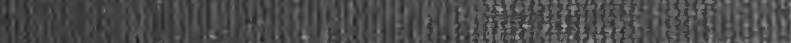
9 9.5

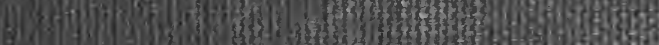

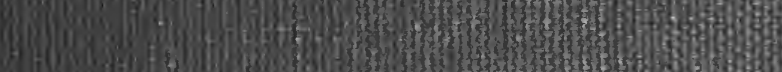
f(ND.)

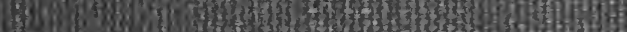
A Mon

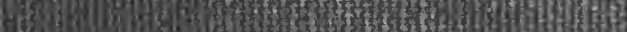
6! - W. Sor.

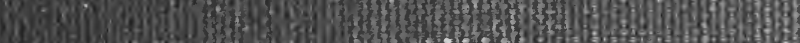
3003 3250.

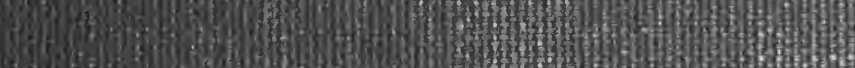

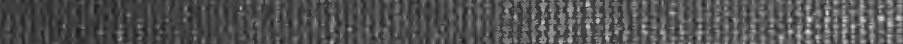
23. 1) Ag 



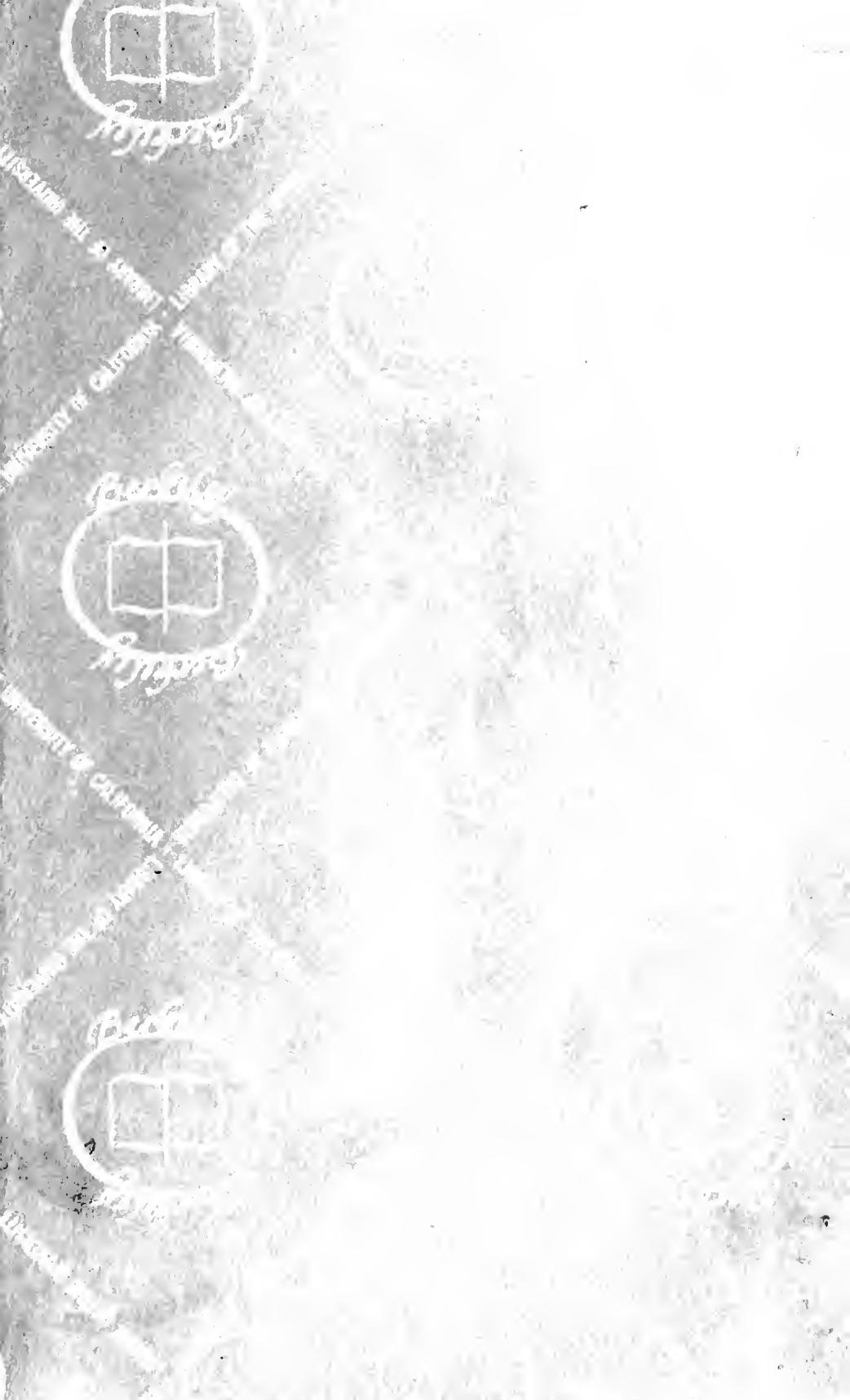




Digitized by the Internet Archive in 2007 with funding from Microsoft Corporation 


\title{
THEORY OF POLITICS:
}

\author{
AN INQUIRY
}

INTO THE

\section{FOUNDATIONS OF GOVERNMENTS,}

\author{
AND THE
}

CAUSES AND PROGRESS

OF

P OLITICAL REVOLUTIONS.

BY

\section{RICHARD HILDRETH,}

AUTHOR OF " THE HISTORY OF THE UNITED STATES OF AMERICA," ETC.

\section{NEW YORK :}

HARPER \& BROTH E R, 329 \& 331 Pearl Street.

1854 . 


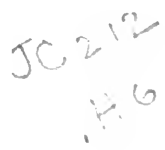

Entered according to Act of Congress, in the year 1853, by RICHARD HILDRETH,

In the Clerk's Office of the District Court of the District of Massachusetts. 


\section{THEORY OF POLITICS.}

Brutus. Another general shout!

I do believe that these applauses are

For some new honors that are heaped on Cæsar.

Cassius. Why, man, he doth bestride the narrow world

Like a Colossus; and we petty men

Walk under his huge legs, and peep about

To find ourseives dishonorable graves.

Men at some time are masters of their fates :

The fault, dear Brutus, is not in our stars,

But in ourselves, that we are underlings.

Brutus and Cosar! What should be in that Cresar?

Why shouid that name be sounded more than yours?

Write them together, yours is as fair a name;

Sound them, it doth become the mouth as well;

Weigh them, it is as heavy ; conjure with them,

Brutus will start a spirit as soon as Cæesar.

Now, in the name of all the gods at onee,

Upon what meat doth this our Casar feed,

Thut he is grown 60 great?

Julius Casar, acti. sc. 2. 


\section{A D VERTISEMENT.}

The following treatise, substantially as it now appears, was composed about twelve years ago. The views it contains having been confirmed in the author's mind by subsequent reading and reflection, it is now published, with a few alterations and additions, principally suggested by occurrences since the date of its original composition.

The Theory of Wealth referred to in it, and forming a necessary part of the design, was written at the same time. Should a demand for it be indicated by the reception of the present volume, it will speedily be forthcoming.

The author specially commends this treatise to the attention of such critics as have complained that his History of the United States has no "philosophy" in it.

R. H.

Bosron, January 31, 1853. 



\title{
C N TENTS.
}

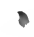

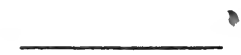 \\ PART FIRST. \\ ELEMENTS OF POLITICAL POWER.
}

\section{CHA P TER I:}

The Political Equilibrium called Government.

Sectiox

Page

1. Various Forms under which this Political Equilibrium presents itself, . . . . . . . . . . • • . . 13

2. Forces which produce a Political Equilibrium, . . . . . 16

3. Means whereby a Political Equilibrium is sustained or overturned, . . . • . . . . . . • • . . 23

4. Anarchical Logical Results of the Metaphysical Theory of Natural Human Equality, • . • • • • • • • . 26

5. Proposed Inquiry into and Analysis of the Partioular Sources of Political Authority, . . . . . . • • • . 29

\section{CHA P TER II.}

Primary Elements of Power, or Intrinsic Sources of Inequality.

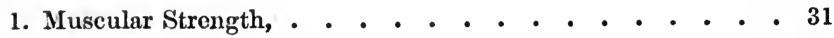

2. Skill, Dexterity, or Art, • • . • • • • • • • • 83

3. Sagacity, • • • • • • • • • • • • • • • 35

4. Force of Will, . . . . . . . . . . . . . 36

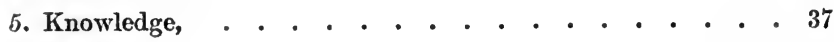

6. Eloquence, . . . . . . . . . • • • • . 44

7. Virtue, . . . . . . . . . . . . . . 46 
CHA PTER III.

Secondary Elements of Power, or Extrinsic Sources of INEQUALITY.

1. Wealth, . . . . . . . . . . . . . . 49

2. Traditionary Respect, . . . . . . . . . . . 54

3. The Idea of Property in Power, . . . . . . . . . 55

4. Influence of Mystical Ideas, . . . . . . . . 56

5. Combination, . . . . . . . . . . . . 63

6. Aggregation, . . . . . . . . . . . . . . . . 68

7. Illustration from the Iliad, . . . . . . . . . 69

\section{PART SECOND.}

FORMS OF GOVERNMENT AND POLITICAL REVOLUTIONS.

\section{CHAPTER I.}

\section{Commencement of Organized Government.}

1. Communities in which there is no Organized Government, . 71

2. Causes which lead to the Establishment of an Organized Government-War, . . . . . . . . . . . . . . 73

3. Accumulation of Wealth, . . . . . . . . . . 75

4. Influence of Mystical Ideas, . . . . . . . . . . 78

\section{CHAPTER II.}

Development and Growth of the Original Monarchy.

1. Limited Extent of the Embryo Monarchy, . . . . . . . 81

2. Passage from the Hunter to the Shepherd State. Commencement of the Accumulation of Wealth, . . . . . . . 82

3. First Effect of this Change - Increase of Paternal Authority, 82

4. Second Effect - Introduction of Domestic or Chattel Slavery, 84

5. Third Effect - Introduction of Organized Government, . 85 
6. Extension given by Agriculture to Chattel Slavery, . . . . 86

7. Influence of Mystical Ideas a Substitute for Chattel Slavery.

Mystical Form of Social Slavery, . . . . . . . 87

8. The Chieftain becomes a King, . . . . . . . . 88

9. Extension of the Original Kingdom by Conquest, . . . $\quad 89$

10. Contact of Shepherd Kingdoms with Agricultural States, . 91

\section{CHAPTER III.}

Oligarchies, Aristocracies, Tyrannies, Secondary Monarchy.

1. Circumstances under which a Higher Political Development becomes possible, . . . . . . . . . . . . .

2. Illustrations from Grecian History. The Primitive Greek Kingdoms, . . . . . . . . . . . . . . . 98

3. Greek Oligarchies, Aristocracies, Democracies, Tyrannies, . 99

4. Greek Revolutions. Secondary Monarchy, . . . . . 102

5. Illustrations from Roman History, . . . . . . . 104

$$
\begin{aligned}
& \text { CHA P TER IV. } \\
& \text { Revolutions of Mrstical Governments, . . } 108
\end{aligned}
$$$$
\text { CHAPTER V. }
$$

Distribution and Division of Authority. - Mrxed Forms of Government.

1. State of Things that attended and followed the Downfall of the Roman Empire. Serfdom substituted for Chattel Slavery, . . . . . . . . . . . • . . 111

2. Origin and Character of the Feudal System, . . . . . 114

3. Monarchy as an Element in the Feudal System, . . . . . 115

4. The Power of the Clergy as an Element in the Feudal System, 117

5. The Feudal Age Municipalities. Their Freedom from Chattel Slavery. Origin and Fundamental Ideas of Modern Democracy, . . . . . . . . . . . . 119 
6. Laboring Mass of the People. Approaeh, during the Feudal Times, to the Introduction into Europe of the System of Castes, . . . . . . . . . . . . . . . . . 124

7. Development, in the Feudal Times, of the Idea of a Mixed Government, . . . . . . . . . . . . . 125

8. Mutual Relations of the Several Orders during the Feudal Times, . . . . . . . . . . . . . . . 127

9. Rise and Progress of the Political Power of the Legal Body, 129 10. Distribution of the Functions of Government. Subdivisions of Authority, . . . . . . . . . . . . . . .

\section{CHAPTER VI.}

Delegated and Representative Authority.

1. Delegation of Power in Monarchies, . . . . . . . . 137

2. Delegated Authority in Republies. Representation, . . . 138

\section{A P TER VII.}

Process by which Democracies are transformed into Aristocracies, Oligarchies, Trrannies, and Secondary MonARCHIES,

\section{CHAPTER VIII.}

Difference between Patrician and Civic Aristocracies.

1. Comparison of Civic and Patrician Aristocracies, . . . 148

2. Wealth as an Element of Power. Moneyed Form of Social

Slavery, . . . . . . . . . . . 151

\section{CHAPTER IX.}

Additional Illustrations from History.

1. What we call Universal History, . . . . . . . 158

2. Ancient Period, . . . . . . . . . . . . . 162

3. Middle Period, . . . . . . . . . . . . . . 166

4. Modern Period, . . . . . . . . . . . . . 168 


\section{PART THIRD.}

GOVERNMENTS IN THEIR INFLUENCE UPON THE PROGRESS OF CIVILIZATION, AND UPON HUMAN HAPPINESS IN GENERAL.

\section{CHA PTER 1 .}

Defintiton of the Terms Liberty, Slafery, and Civiluzation, 227

\section{CHAPTER II.}

Effects of the Different Kinds of Government.

1. Test of the Degree in which Governments inflict Pain, . . 232

2. Operation of Governments founded upon Conquest, . . 234

3. Of Tyrannies, or Governments supported by Mercenary

Standing Armies, . . . . . . . . . . . . 237

4. Of Theocracies, . . . . . . . . . . . . . 239

5. Of Governments based on Hereditary Respect and the Idea

of Property in Power, . . . . . . . . . . . . 243

6. Of Civic Aristocracies, . . . . . . . . . . . 244

7. Of Mixed Governments, . . . . . . . . . . 249

8. Of Democracies, . . . . . . . . . . . : 251

\section{CONCLUDING CHAPTER.}

Hopes and Hints as to the Future, • • 267 



\section{THEORY OF POLITICS.}

\section{PART FIRST.}

ELEMENTS OF POLITICAL POWER.

\section{CHAPTER I.}

THE POLITICAL EQUILIBRIUM CALLED GOVERNMENT.

\section{Section First.}

Various Forms under which this Political Equilibrium presents itself.

Casting our eyes over the world with special attention to its human inhabitants, we find men every where, a few savage tribes excepted, living together under distinctly-organized forms of government, which, though, upon a close inspection, exceedingly various, are yet capable of being all arranged under a few ${ }^{\circ}$ general heads.

1. In a large number of communities, we see the entire legislative, judicial, and executive authority vested in a single individual, by whom it is exercised either in person or by deputies of his own independent selection. This general form, called Monarchy, admits, however, of numerous varieties, as well in 
the extent of authority as in the grounds upon which that authority appears to rest. In some states, it is sustained by a standing army, or by a powerful militia of devoted followers, who look up to the ruler as their military chieftain. In others, the monarch is revered either as an incarnate God, or else as God's chosen deputy and appointed earthly vicegerent. The power of some monarchs appears to rest on genealogical traditions, transmitted with religious care, and received with implicit faith, according to which they represent the person and inherit the authority of some mystic ancestor, from whom the whole community traces its descent; the power of such monarchs partaking largely of a paternal, and their subjects' submission of a filial character. Other monarchical rulers seem to owe their position, entirely or chiefly, to their superior courage, activity, sugacity, or eloquence; sometimes to superior wealth; sometimes to the respect or favor inspired by benefits, or supposed benefits, conferred upon the community. In very many other cases, several or all of these sources of authority combine to elevate the ruler to his station of monarch.

2. There is to be observed a small number of states, in which the form of government is not a monarchy, but an Oligarchy; some three, four, ten, or a hundred persons sharing between them the control of public affairs. But this form is far from common, since it tends constantly to pass either into a monarchy or into that form next to be described.

3. This third form of government is that called Aristocracy; the administration of affairs being vested in a larger, but still a limited number, who, or a majority of whom, appoint the magistrates, make the 
laws, and decide all cases, criminal and civil, either in person or by deputies whom they select.

4. There is still a fourth form of government, called Democracy, in which the right to legislate and to judge, as well as the appointment of executive magistrates, who hold their offices for limited terms, rests with the majority of the male inhabitants of mature age, or with persons whom that majority, immediately or mediately, appoints and displaces.

But besides these differences of form, there are other differences to be noted, not less obvious, and still more essential. What has been already observed of monarchy is also true of the other forms of government. In some states, authority is great, and submission entire; while, in others, both authority and submission are exceedingly limited. In some governments, all acts of authority are exercised according to certain fixed rules, called Laws; while, in others, every thing almost seems to depend upon the temporary judgment or caprice of the ruling power, or its deputies. In some states, all the subjects stand upon a level of equality ; in others, they are arranged in ranks and orders.

Turning from the present to the past, and reviewing such fragments as remain to us of the history of mankind, we find in all ages and countries sufficient coincidence in the forms and varieties of governments to show that those forms and varieties must every where have been determined by the same general laws.

And the same is true of the changes which governments undergo, passing from one form to another, or from one variety to another of the same form, sometimes by processes so slow and quiet as to be almost 
imperceptible, sometimes by sudden and violent revolutions.

To him who with his mind's eye runs over this various scene the question cannot but forcibly recur, What is it that causes governments to exist? Whence the various revolutions which they undergo? What are those sources of power, those elementary forces, from the balance of which springs that political equilibrium which we call Government, and from the disturbance and overturn of which arises what we call Revolution, ending, in its turn, by producing a new equilibrium, a new government, itself again liable to new disturbances, producing new revolutions and new governments, and so on in apparently endless succession?

\section{Section Second.}

\section{Forces which produce a Political Equilibrium.}

When we come to scrutinize and to classify the motives by which human actions are impelled, there appears among the number one of very obvious and general operation, which may easily serve to account for the existence of governments, so far, at least, as those who govern are concerned. This motive is, the Pleasure of Superiority - that pleasure which men fecl, not merely in the acknowledgment by others of their superiority, but in the practical exercise of it; an impulse of mighty moment in human affairs, great and small. In its political operation, this motive is commonly known by the term Ambition; and this motive it is which constantly supplies such a host of candi- 
dates for every dignity, from the paltriest village magistracy up to the stations of prime minister or king - candidates who, in spite of the cares and vexations which such positions generally involve, are ready to incur expenses and obligations, to labor night and day, and even to submit to manifold humiliations, to obtain them.

This sentiment, however, is far from being sufficient to account, by itself, for the phenomenon of government; since, by the very same force with which it impels men to seek the position of governors, it impels them also to avoid and escape from the position of subjects. Here, indeed, we discover the chief cause, the motive power, of all political revolutions - a cause always active, and which, unless repressed by other more potent causes, or provided with some safer and more limited field of exercise, will be forever producing revolutions, or, if not revolutions, rebellions, anarchy, and civil commotions. There never can, indeed, be any settled obedience or quiet submission on the part of the governed, until the pain of inferiority, which the position of subjects naturally tends to inspire, is counterbalanced or neutralized by the operation of other sentiments.

It is not in human nature quietly to submit to any merely assumed superiority; nor is there any basis upon which such an assumed superiority can be sustained for a moment, except a persuasion, well or ill founded, on the part of the subjects, as well as on the part of the rulers, of an actual superiority on the part of those rulers - a superiority either substantial and permanent in its nature, or, at least, accidental and temporary; at all events, sufficient, for the moment, 
to make it folly to attempt resistance; such resistance, if attempted under such circumstances, being sure, or, at least, likely, to end in failure - a result pretty certain to make the yoke heavier.

This persuasion of an actual superiority, while it inspires the rulers with fresh resolution to maintain their power, produces on the part of the governed a threefold set of motives for submission - first, Fears; secondly, Admiration; thirdly, the Idea of the moral Duty of obedience.

1. Fears, though they relate to a more or less distant future, are yet, in their character of pains of apprehension, - for such they are, - present and immediate in their operation as motives, and very potent in their influence upon human conduct. These fears are of two kinds - such as may be called vain, imaginary, unfounded, and such as are reasonable and just; and though, with the progress of intelligence, vain fears, founded on imaginary dangers, by which the conduct of the rude and ignorant is so extensively influenced, die out by degrees, yet the influence of fear; thus gradually transformed into a rational dread of future consequences comprehensively foreseen, comes to have a greater and greater influence over human action; so that the more civilized and intelligent a community becomes, and the more complicated its social relations, the greater will be the efficacy of this motive in producing submission to any existing government.

Fear, however, though multifold in its operation, (since the dread of falling under certain apprehended exercises of power will constantly prompt to submit to other exercises of it, in the hope of thus obtaining protection,) is very far from being the pillar upon 
which the authority of governments most securely rests. That pillar is the sentiment of Admiration, and the pleasures which that sentiment affords; subsidiary to which is the moral Sentiment.

2. Over the operation of the desire of superiority, as over every other emotion, habit and the apparent possibility or impossibility of its gratification have a very powerful influence. It is only with respect to those whom we have been accustomed to regard as our equals or inferiors that this sentiment exercises its full force. As regards those whose superiority over us is unquestionable and apparently irrevocable, the pain of inferiority is felt in a very slight degree, assuming the form of embarrassment, or what is called bashfulness; or it may be wholly superseded and displaced by pleasures of Admiration.

In proportion as a man, or body of men, can excite these pleasures of admiration in our minds, in that same proportion do they become objects to us of benevolence, and in that same proportion are we disposed to sacrifice our own pleasure and interest to theirs. Such is the origin of what has been, aptly enough, termed " hero worship" - that loyal and selfsacrificing devotion to the interests and wishes of political and ecclesiastical chiefs of which we see every day such striking instances, and which every where constitutes the most solid and reliable basis of power and authority.

3. It is as a subsidiary support to this great original basis of power that the idea of Duty comes in. To the reflecting mind the absolute necessity of some sort of government is sufficiently obvious - so obvious, indeed, that many speculative writers have assumed 
that government took its origin in the perception of its utility, men having deliberately established it because they felt its necessity. But in this case, as in many others essential to the existence of the race, mankind have not been left to the slow deductions of reason, governments having sprung up out of the very constitution of human nature, long before men had become reflective enough to perceive their practical benefits. Yet those benefits, once perceived, and especially when made the more striking by the contrast of recent commotions or civil war, come to constitute a very strong argument in favor of upholding and strengthening the hands of any such government as happens to exist, since the mere fact of its existence goes very far to prove its rightfulness and legality.

For, as actual superiority on the part of the rulers constitutes the only basis upon which government can securely rest, so the might to govern must of necessity carry with it the right to govern; and in this sense,- - and a very important sense it is, too, - Might does actually make Right.

Nor, when taken with its proper restrictions, will this maxim appear so very paradoxical. Those who have the might to govern have the right to govern, but not the right to govern tyrannically. As is the case of a father with respect to his children, so all rulers are morally bound to use that power which the constitution of nature has put into their hands, not to the injury of others, or for their own special benefit, but for the common good of the nation - the joint benefit of all concerned; not in accordance with their own arbitrary will and pleasure, but in conformity to the higher law of moral obligation; and every exercise 
of power of a different character, from whomsoever it may come, is, and always will be, none the less, on that account, tyrannical and wicked.

Yet every mere abuse of power is by no means to be made an excuse for attempts at the overturn of existing governments, which can be justified only by some fair prospect of success, and of the substitution of a better one in the place of that overturned. And, as actual success affords the best proof - in fact, the only satisfactory proof - that the enterprise was not rashly undertaken, hence does it mainly depend upon the ultimate result, whether the leaders in such undertakings sink into obloquy as unsuccessful rebels, or rise to renown as patriotic heroes.

Thus, in the Christian theology as set forth in Milton's great poem, the right of God to govern, and the duty of men and angels to obey, are made to rest upon the power of God, who is represented as having created men and angels solely for his own pleasure and glory; while the guilt of Satan's rebellion grows out of the hopelessness of it. In the heathen mythology, on the other hand, Jupiter dethrones his father, Saturn, and becomes his rightful successor. His might makes and proves his right.

In all cases, historical as well as mythological, an authority or possession de facto, if it continue to be maintained, soon passes into an authority or possession de jure. The maintenance of it proves the might, and the might proves the right. Nor, indeed, is any very great length of time necessary to produce that effect. Robespierre, having been able to maintain the sovereign authority for less than a twelvemonth, is generally regarded as a usurper and tyrant; while 
Bonaparte, by holding it for some fourteen years, passes, with many of these very same persons, into the rank of a legitimate sovereign.

Yet, while the moral sentiment thus contributes so powerfully to the sustentation of existing governments, nevertheless there are cases, the governors grossly disregarding the higher law of moral obligation, and obviously employing their power in total disregard of the public interests, and for the sole benefit of themselves and their favorites, - the prospect also appearing of a beneficial change, - in which that same moral sentiment which before prompted obedience becomes one of the strongest impulses to resistance to authority.

Nor ought we wholly to omit from the list of secondary motives which may coöperate in the minds of governors, in conjunction with the sentiment of superiority, to prompt to exercises of power this same moral sentiment; since it is certainly possible that power may be sought and used as a means of gratifying the sentiment of benevolence by conferring favors on those whom we love - within which purview may possibly be included the great body of the community; though, in general, the limits of the benevolence of the governing power are apt to be a good deal more narrow, and this motive itself, whatever the sphere of its operation, to be much more ostentatiously put forward than facts will warrant. A far more effectual secondary motive is, on the part of the rulers or those seeking to become such, the Desire of Wealth, since political power furnishes to those who possess it the means - in general, pretty effectual of securing to themselves - for the most part at the 
expense of the governed - wealth and all that mass of pleasures which wealth is able to procure; and hence the compound influence of all those sentiments which wealth is able to gratify commonly unites with the love of superiority to impel those who govern to retain and to extend their power.

But, as this desire of wealth on the part of the governors can, for the most part, only be gratified at the expense of the governed, this same desire of wealth operates with a corresponding impulse on the governed to impel them to resist the authority of governors, when it is obviously exercised for their impoverishment. Hence the common observation, that subjects feel most acutely through their pockets ; and hence it has happened, though many other acts of government have a much more certain and permanent tendency to the national impoverishment than a mere increase of taxes, yet, as taxation has that effect most palpably to the vulgar mind, that so many famous political revolutions have originated, or, rather, have taken a start from the imposition of new taxes.

\section{Section 'Thind.}

Means whereby a Political Equilibrium is sustained or overturned.

Whenever the mutual play of the forces enumerated in the preceding chapter has resulted in the establishment of any given political equilibrium, or system of government, one of three things must of necessity follow. 
1. The motives by which the governed are prompted to submit to authority form an exact counterbalance to those which prompt them to resist - in which case, so long as the governors attempt no new stretch of authority, the subjects quietly obey; but should the governors attempt to increase their power, - to which all governors are under constant temptation, - in default of some new motive to prompt to submission, these attempts will be met and resisted. Often, indeed, from the very circumstance that such resistance is foreseen and dreaded, no such attempts will be made, governors, whenever the potency of their authority begins to be questioned, being liable to fall under the influence of fear equally with the governed. 'This supposed condition of things is that of a stationary political equilibrium - a government and state of society steady and unchanging. Among political speculatists of former times, from Plato downward, it has been a great object to discover the secret of such a stationary political equilibrium; but, like many other secrets for which men have anxiously sought, it is, most likely, a mere chimera of the fancy, which, were it discoverable, it would by no means be desirable to put into practice. So far as our information extends, no instance ever actually occurred of such a stationary political equilibrium, though a pretty near approach to it has been made by some theocratic governments.

2. Or, secondly, the motives, on the part of the mass of the community, which prompt to obedience being stronger than those which prompt to resistance, the governors, impelled, as they constantly are, by the love of power to increase their authority, go on in- 
creasing it, till, by the new intensity thus given to the pain of inferiority on the part of the governed, resistance is roused, the encroachments of the governors are checked, and the equilibrium is restored.

3. Or, what, under such circumstances, is much more likely to happen, a movement takes place in the opposite direction; the result being that third case, in which, the motives that prompt to obedience on the part of the governed being inferior in force to those that prompt to resistance, a resistance, greater or less, is steadily opposed to the authority of the government. This resistance is of two degrees - that which is called unarmed, passive, and sometimes moral resistance, consisting in complaints, reproaches, petitions, and the refusal to aid in enforcing the laws; and that which is the same in its origin, substantial nature, and tendency, though different in degree, violent and armed resistance, active opposition to the enforcement of the laws. Unarmed resistance, if sedulously persevered in, produces often, by a gradual modification in the form and character of the government, revolutions in no respect the less complete and entire because they take place by almost imperceptible degrees. Armed resistance is exhibited in revolts, coups d'état, and civil wars, producing sudden and violent changes.

Some lovers of liberty, but, at the same time, lovers of peace and social order, have attempted to draw a distinction between armed and unarmed resistance, as though the one were a lawful and commendable resort, and the other not. And doubtless, in what are called constitutional forms of government, - governments, that is, in which the right of the governed to resist by certain peaceful means, and to attempt to 
modify the action and even the spirit and form of the government, is admitted, - this distinction is sound and just. Nor, indeed, is armed resistance often resorted to, - at least by any spontaneous impulse on the part of considerable masses of the people, however it may be with ambitious individuals and those acting under their influence, - except where unarmed resistance is prohibited, or has been tried to no purpose. Unfortunately, there have been, and are, in the world, very few governments in which the right of passive or unarmed resistance is acknowledged. By most governments, such resistance is considered and treated as no better than open rebellion, which thus becomes the sole resource of oppressed subjects.

\section{Section Fourth.}

Anarchical Logical Result of the Metaphysical Theory of Natural Human Equality.

IT would appear, from the preceding review of the circumstances under which political equilibria - that is to say, systems of government - are established, overturned, and reëstablished, that the secondary motives - to wit, the moral sentiment and the desire of wealth - which impel to the exercise of power are precisely the same secondary motives which impel to resistance to it. And as the primary motive - to wit, the love of superiority - which leads men to seek power, and to resist the exercise of it over them, is also the same, and as the motive of fear, all other things being equal, would operate equally upon both 
sides, we should have, but for a sense of actual superiority on the one side, and of inferiority on the other, such a complete counterbalance of impulses as would not allow, to be either attempted or submitted to, any steady exercises of power, such as we see going on every where around us.

Such being the case, we have no occasion to wonder that, among those who have adopted the metaphysical theory of the natural equality of men, the idea has been started of the possible existence of society, not only without laws and without government, but without any exertion of power by men over each other. Indeed, there have not been wanting some very refined speculators upon morals and politics, who have boldly advanced the opinion that the abolition of governments, and, indeed, of all control and authority, is not only possible, but a thing practically to be aimed at; though none of these persons seem to have attained to any very distinct idea of the condition necessary to the existence of such a state of society.

That condition evidently is, not only a perfect equality in all respects, - an equality assumed as the natural state of the human race by the metaphysical theory above alluded to, - but, in addition, the perception and admission of that equality by every member of the community, not merely as a theoretical possibility, but as an actual present fact. As, under such circumstances, injurious exercises of power would not take place, or would be instantly repelled and punished, remedial exercises of power from a source exterior to the injured individual would not be needed, and the necessity for government would be superseded at the same time with its possibility. 
But where such an equality neither exists nor is believed in, - every where, that is, in the world of fact, past and present, - where there is an apparent and admitted inequality, not only does the motive of fear preponderate on the side of those who see themselves inferior, to produce, on their part, yielding and submission, but the perception of that inferiority produces in their minds the moral sentiment of the duty of submission - so long, at least, as those in authority conform themselves, in the exercise of it, to the supereminent law of moral obligation; while, at the same time, the contemplation of their admitted superiority gives rise to pleasures of admiration, such as tend to make obedience not a duty merely, but a delight also, and that independently of moral considerations. Under these influences, governments, even very oppressive governments, come to be regarded, even on the part of the subjects, not as necessary evils to be submitted to, and at the same time to be reduced within the narrowest possible limits, - such as the theorists of equality would represent government always to be, even under its best estate, - but rather as an ordinance of God and nature, - as much so as the change of seasons or the necessity of labor, attended, indeed, by some inconveniences, but still beneficent and fruitful in good; at all events, an inevitable law to which society must conform itself. 


\section{Section Fifth.}

Proposed Inquiry into and Analysis of the Particular Sources of Political Authority.

To ascertain with distinctness the precise sources of authority, their extent, and natural limits, and particular methods of operation, it becomes necessary to inquire what those things are with respect to which, or by reason of which, there exists an inequality among men, intrinsic or extrinsic, and which, accordingly, by giving rise to pains of fear and to pleasures of admiration, prevent the motives which impel to resistance from attaining a force equal to that of the motives which impel to the exercise of authority; in consequence of which a perfect equality, and with it the non-existence of government, are nowhere to be found; but submission on the one side, and authority on the other, always exist, constituting, when they take on an organized form, that political equilibrium which we call a government.

If we find, in the course of this inquiry, that certain sources of inequality exist so permanently in the constitution of man that the state of things which would render government at once impossible and unnecessary seems to be quite out of the question, for the future as well as for the present, - at least till human nature itself shall have undergone some radical change, - we shall also find that certain other sources of inequality, hitherto and still exceedingly influential in their effects upon human society, owe their entire or chief efficacy to error or falsc opinion, 
and that even permanent sources of inequality are, in practice, greatly aggravated by artificial means.

Learning thus to give over the dream of any such perfectibility in human nature, even under the most favorable circumstances, as will dispense with the necessity for government, we shall, however, discover that the elements of fraud, fear, and force, which now, in most governments, play so conspicuous a part, are capable of being superseded, to a great extent, if not entirely, by those of intellectual conviction and consent; thus purging the exercise of authority of many of the evils by which it is usually attended, and reducing it to the lowest degree compatible with the nature of man and the welfare of society, for the entire development of which, the joint coöperative efforts of the whole community are no less essential than the separate individual exertions of its members. 


\section{CHAPTER II.}

PRIMARY ELEMENTS OF POWER, OR INTRINSIC SOURCES OF INEQUALITY.

\section{Section First.}

\section{Muscular Strength.}

ThE first and most obvious source of inequality, foundation of authority on the one hand, and occasion of submission on the other, is inequality in Muscular StRength.

The original and most simple kind of government is that which exists in the family, and which, under all forms of political society, still continues to exist, with but few modifications. 'The father of the family, unless the municipal law interfere to restrain his authority, is its absolute head, with supreme legislative and judicial functions, including the power of life and death over its members. The Chinese code formally sanctions this extensive authority, and the old Roman law did the same. The English law restricts the authority of the father and husband to the right of moderate personal castigation, and even that right, so far as the wife is concerned, is taken away by the American law.

One chief source of this originally-unlimited power on the part of the father is his superior bodily strength - apparent enough as respects the children doring their infancy, and, as respects the mothers of those children, sufficiently so, in the great majority of cases, for all practical purposes. 
Resting, in a great degree, upon his superior strength, the authority of the father naturally terminates with the termination of its cause. When the sons attain a strength equal to that of their father, their subjection, unless protracted by other causes, presently to be noticed, naturally ceases, and his rule comes to an end.

Though, in the savage state, the rule of the father over his family be absolute, he seldom attempts to convert his children into a source of profit. But this does not proceed from any peculiar tenderness on the part of savage fathers, so much as from the want of means or opportunity. Where the slave trade flourishes, savages do not hesitate to sell their own children; while, in all savage and barbarous communities, the females are little better than slaves, marriage being, in fact, a sort of purchase. Indeed, as the inferiority of women in point of strength is not temporary merely, but permanent, and as the same may be said of their relation to men as to all the primary elements of power, hence that position of inferiority which women continue to occupy, even in the most enlightened communities; seldom obtaining, and that only in rare and exceptional instances, and, for the most part, too indirectly, any share of political power.

The order of nobles in the South Sea Islands are a taller and stronger race than the common people; and the same has been observed in many other countries. In the ancient republics, bodily strength was assiduously cultivated by the exercises of the palæstra, which were esteemed, and not without reason, of the greatest political importance. The exercises of the 
tournament during the middle ages, and the preparations necessary for it, were precisely of a similar character.

In modern times, individual bodily strength has lost the greater part of its political importance, principally from a circumstance which will presently be adverted to. Yet, even as respects individuals, a high degree of bodily vigor, the capacity to undergo labors and fatigue, is very essential to political eminence; while strength, not individual, but combined, or aggregated, in the manner to be presently pointed out, remains, and always must remain, the ultimate support and substratum of political authority.

\section{Section Second.}

\section{Skill, Dexterity, or Art.}

Nexr to strength, as a natural and primary source of inequality among men, may be placed inequalities of Skill, Dexterity, or Art; this being a means whereby strength is made more available, and deficiency of strength is supplied.

Those sorts of dexterity which have the most direct and immediate reference to political power are, first, dexterity in the use of martial weapons; secondly, dexterity in the arts tending to the production and accumulation of wealth - for the possession of wealth, as we shall presently see, is a most important element of power.

1. It appears, from the history of all nations, ancient and modern, that, whenever the supreme polit- 
ical power is exercised by a particular class, to the exclusion of the rest of the community, - except in governments resting mainly on a theocratic basis, the members of that ruling class - with some slight exceptions, the origin and occasion of which will presently be explained - always have arms in their hands, and sedulously employ themselves in increasing by exercise their skill in the use of them. The exercises of the palæstra, and the chivalrous exercises of the middle ages, already referred to, tended to an increase of dexterity, not less than of strength. The declamations against luxury, and even against literature, with which ancient writers abound, chiefly originated in the circumstance that, with the increase of refinement, the ancient games and warlike exercises, which tended to increase strength and military skill, fell into neglect; the ruling order seeking amusement in occupations, such as music, poetry, literature, the fine arts, the refinements of the table, \&c., unfavorable, by the sedentary habits which they introduced; to warlike dexterity, no less than to bodily strength, and which tended, therefore, to undermine and to endanger the existing political equilibrium.

In the highly-civilized communities of modern times, the ruling. class do not always think it necessary to be, all of them, individually skilled in arms; but the officers of the military, on whom, in modern warfare, every thing depends, are uniformly selected from the ruling class, and make a part of it. Thus, in British India, though the armies are largely composed of native soldiers, the officers are all British.

The invention of gunpowder, and the subsequent improvements in artillery and firearms, by rendering 
war not an affair of individuals, but of aggregated masses; by placing the strong and the weak, in many respects, almost on a level; by superseding the necessity - at least on the part of the soldiers - for constant exercise, inasmuch as adequate skill in the use of these arms is easily acquired; and especially by making war an affair of science, - have destroyed, to a great degree, the influence both of individual strength, and of individual dexterity in the use of arms, as elements of warlike success, and thcreby of political power.

2. On the other hand, dexterity employed in the acquisition of wealth - a head embracing a great variety of particulars, sufficient for a treatise by itself has constantly gained in importance, as, with the diminution of the influence of some other sources of authority, wealth has constantly acquired increasing importance as an element of power.

\section{Section Third.}

\section{Sagacity.}

$\mathrm{W}_{\mathrm{E}}$ enumerate, as a third original source of inequality, and primary element of power, inequalities of $S_{A G A C I T Y}$, by which term we indicate the mental - capacity of comprehending the position of affairs, and of perceiving the best application, under the circumstances, of such strength and skill as may be at one's disposal. Although this inequality depends originally upon a natural difference, in different individuals, in the force of the rational and conceptive faculties, yet 
it is very much aggravated by position and education. And it may be stated, as a general rule, that the governing class in every community will be found to enjoy very decided advantages in point of education and mental training; or if, in any community, these advantages come to be equally shared by the subordinate class, from that moment the authority of the governing order becomes very precarious.

\section{Section Fourth.}

\section{Force of Will.}

UNDER this common head we class together the temperaments or qualities of Activitr, Courage, Fortitude, Self-Control, or Policy, and Perseverance - qualities between which there exists a certain close association and intimate connection, yet which are by no means inseparable, some of them being occasionally possessed in a high degree where others are deficient. Perhaps, from this circumstance, they ought rather to be separately enumerated, as distinct elements of power. Yet they mutually strengthen each other, and their just combination is essential to that resolute, and at the same time judicious vigor of action, of so much weight in all human affairs.

As respects all these qualities, a certain degree of inequality originates, no doubt, in personal idiosyncrasies. They are, in fact, very dependent on original stamina of constitution and the state of the bodily health. But the inequality that actually exists, especially as regards masses of men, depends very 
much, also, as in the case of sagacity, upon position and education. To a certain extent, these qualities are natural attendants upon the possession of power and that sense of superiority by which power is accompanied; whilst deficiency as to all of them naturally results from that sense of inferiority attendant upon a subordinate position.

\section{Section Fifth.}

\section{Knowledge.}

The aphorism of Bacon that KNowledge is power has passed into a proverb. Why knowledge is power is sufficiently evident. There may be many different ways of doing the same thing, some of which require much less strength than others. These easier ways of accomplishing any given object are discovered sometimes by accident, sometimes by superior sagacity. Accumulated and transmitted, they form the stock of knowledge, or a part of it; all knowledge being either traditionary, or else the joint result of superior sagacity and an enlarged experience. As there are many kinds of knowledge to the possession of which personal experience is essential, hence the superiority, in this particular, of age over youth, and hence the distinction between book knowledge, or learning, and what is called practical knowledge, or experience.

Whether received by tradition or originating with ourselves, knowledge, by pointing out to us, among several means of accomplishing an object, that which 
is easiest, stands often in the place both of strength and dexterity. Indeed, what is called dexterity, or art, often mainly depends upon superior knowledge.

Human strength is a limited quantity, of which the total amount can only be increased by increasing the total number of individuals - a process very slow and often narrowly restricted. Human knowledge is an unlimited quantity, capable of being increased often with vast rapidity, and to an indefinite extent. Thus indefinitely increased, though combined with but a limited degree of strength, it may produce an effective power of indefinite energy. Hence it is that the increase of knowledge is so generally looked to as the chief means of diminishing the evils under which the human race now suffer, and of increasing the pleasures which they may enjoy.

Reading and writing are not knowledge, but they are the means of knowledge; and by the help of the press, especially of the periodical press, they are becoming every day more effectual and extensive in their operation. Yet, in this climbing by the ladder of the press out of the pit of ignorance, for every three steps that are taken forward, at least two steps are generally taken backward; since reading and writing are not only means of knowledge, but means, also, hardly less potent, for the diffusion of error, which, though it be often a necessary preliminary to knowledge, is, in many of its immediate effects, even worse than ignorance.

It is customary to date what is called the revival of learning in Europe from the discovery of printing. But, to trace the course of modern science, it is necessary to go back to a period considerably earlier - to 
the introduction of the art of paper making, which, by facilitating the multiplication of books, had produced very perceptible results before types were invented, and but for which, their invention would have been of little use.

Cotton paper, the kind first used in Europe, was a precious commodity, brought from the East. The Saracens, it is said, had derived the art of its manufacture from China, by way of Samarcand in Tranoxania, to which province the conquests of both the Chinese and of the Caliphs of the dynasty of the Ommaides had extended. Its use in the west was very limited, Christendom, at that period, being overcast with the deepest ignorance, and few except the clergy being able to read. But it served to supply the place of the Egyptian papyrus, - for many ages previous a principal writing material, - the manufacture of which appears to have ceased soon after the Mohammedan conquest of Egypt, perhaps in consequence of being superseded by the superior article of cotton paper.

Towards the end of the eleventh century, some unknown inventor discovered the art of making paper from linen; and shortly after, that manufacture became flourishing in Spain, whence it gradually spread into the rest of Europe. The multiplication of books was thus greatly facilitated, and the ability to read, no longer confined to the clergy, became diffused first among the wealthier inhabitants of the towns, and presently among the feudal nobility. The popular dialects of Europe began now to be reduced to writing, and to be employed first as the language of poetry, then for prose fictions and histories, and finally for religious and philosophical disquisitions. Already 
readers had become numerous, before the art of printing, known long before in China, was invented in Europe. Supposing it to have been hit upon at an earlier period, it might have failed to come into practical use.

It was not, however, till printed books became common, that the attention of the ruling classes in Europe seems to have been much attracted to reading and writing, as tending both to a diffusion and to an increase of knowledge, hostile as well to that limited monopoly of science as to certain unfounded opinions, which together formed the chief support of the then existing systems of political power. As a check upon these threatened results, two very different sets of preventives were, and still are, resorted to.

1. The first, rudest, and most obvious was discouraging, and, so far as possible, preventing the diffusion of the arts of reading and writing among the mass of the governed, as things of no use to them, but, on the contrary, highly dangerous and inflammatory, tending to discontent, sedition, and revolution - a tendency which, in many existing states of society, they certainly have, and that, too, in a very high degree. Such was the view under which the High Church party in England, down to a very recent period, so warmly opposed the diffusion of the arts of reading and writing, and of book knowledge in general, among the laboring classes of that country. But it is some of the slave states of America that have gone furthest in this direction, by laws prohibiting, under severe penalties, the teaching of slaves (if not, indeed, of the free colored people) to read and 
write - a kind of legislation hardly to be paralleled. in any other age or country.

Correlative to this process as to reading, are restraints put upon writing, or, at least, upon printing and publishing, first by the establishment of a censorship of the press, and, in countries in which it has been found necessary to abandon that, by criminal prosecutions for libellous, seditious, heretical, and irreligious publications; to which may be added limitations put upon the circulation of newspapers, by means of stamp taxes and other contrivances, to enhance their expense - imposed first, perhaps, merely for revenue, but kept up afterwards from political motives; and still, throughout the whole of Europe, in full operation, even in states professing to be the freest.

2. The other method, and a much more ingenious and deeper one, was that introduced by Calvin, Knox, and other more ultra leaders of the Protestant sects, and, among the Catholics, by the Jesuits, and fully carried out by Austria and other German states, according to which the people are all to be taught to read; to be compelled, indeed, to send their children to school ; care, however, being at the same time taken that no books or writings shall get into their hands, except such as have received the imprimatur of the government; reading and writing being thus made instruments for preoccupying and impressing the minds of the young with opinions favorable to the existing system - thus giving new energy to those secondary elements of power, to be hereafter enumerated, dependent upon opinion.

It is their just sense of the powerful efficacy 
of this means which has made the clergy, every where throughout Christendom, Protestant as well as Catholic, so exceedingly anxious to secure, and so tenacious to retain, the exclusive control and direction of all seminaries of education, from universities down to infant schools; and it is, in part at least, to the same cause that is due that disgraceful spectacle exhibited by the British nation, in the face of Europe, the great mass of the population being suffered to lack the very first rudiments of knowledge, for fear lest the church of England on the one hand, or the dissenters on the other, might gain or lose a portion of influence, according as the instruction of the masses in the arts of reading and writing is or is not placed under the control of the established clergy.

Of these two methods of suppressing the increase and diffusion of knowledge, and of keeping the control of the element of power in a few hands, the latter, as it is by far the least effectual, so it is the least pernicious in its operation. For, as has been most sagaciously remarked," "It is one of the peculiarities of the human mind, that it will ultimately derive truth even from the instruction of error; that however carefully developed for any particular purpose, the development itself will go beyond that purpose. A child educated in bigotry is more likely to obtain a large perception of religious truth than a child not educated at all. It is impossible to teach ignorance, for the light that invades and illustrates at the same time dispels the darkness."

* Edinburgh Review, No. 160, April, 1844. Custine's Russia. 
Of the relative operation of these two systems, we may observe an instructive example in the United States of America. The New England common schools were originally established chiefly for the maintenance of religious orthodoxy; or, in the terms of the law by which they were made general, $(1649$,$) to counteract the projects of that "old deluder,$ Sathan, in persuading men from the use of tongues," giving thereby the greater scope to "the false glosses of saint-seeming deceivers, in clouding the true sense and meaning" of the Scriptures. The school system was thus but a part of the machinery of the early New England theocracy, and the schools were long, and still are, very much under clerical influence. And yet the fact is unquestionable, that the free schools of Nę̧v England have been the fountain whence has flowed the whole stream of American heresies, from those of Edwards downward; at least all which tend, like those of Edwards, in a freethinking direction. Nor is it less certain that a freedom of speculative inquiry is beginning plainly to develop itself in that same quarter, from which, in the next fifty years, some fruits may be expected worthy of notice.

In Virginia, on the other hand, - which, with many points in common, may yet be considered, in American affairs, as the antitype of New England, - the other system has prevailed. In answer to certain inquiries from England, in 1671, Governor Berkeley thanked God that Virginia" had "no free schools nor printing," and hoped she might not have for a century, since "learning has brought disobedience, and heresy, 
and sects into the world, and printing has divulged them, and libels against the best government. God keep us from both." The hopes of this loyal and pious governor have been, alas! but too literally fulfilled; and the consequence is, that Virginia, to this day, prints nothing but a few partisan newspapers, while, in activity of intellect, and freedom of speculative inquiry, and even in learning, the present generation is vastly behind that of three quarters of a century ago. There were more ideas in the head of Thomas Jefferson alone than in all Virginia at this moment.

\section{Section Sixth.}

\section{Eloquence.}

Bur sagacity, knowledge, even strength of will, are often to a great extent unavailing, unless aided by Eloquence, which is the power of exciting in other men's minds conceptions, and with them pleasures, pains, and desires; that is to say, motives of action. Eloquence is of two kinds - spoken and written. Written eloquence depends entirely upon the unassisted power of words to call up ideas. Spoken eloquence avails itself likewise of modulation and action. But this is a subject which belongs more particularly to the theory of Taste - the name employed to designate a sentiment, or combination of sentiments, generally regarded as lying somewhat out of the line of ordinary life, but with a much more direct bearing upon it, and a more predominating in- 
fluence over it, than is commonly thought of, and which might well form by itself the subject of a separate treatise.

Of spoken eloquence, the clergy have, in most countries of Christendom, and indeed throughout the world, a complete monopoly. They alone are accustomed or permitted to address promiscuous assemblies. It is only in Great Britain, the British colonies, and the United States of America, that spoken eloquence is employed to any considerable extent for lay purposes.

As to written eloquence, the freedom of the press is absolutely necessary to its complete operation, indeed, almost to its very existence; it being of course limited to those topics upon which freedom of expression is allowed. Where it has free scope, or even a scope partially free, it is capable of producing immense effects. The eloquence of Rousseau and Voltaire occasioned results vastly greater, as well as more permanent, than the eloquence of Demosthenes and Cicero. What, indeed, would have been the reputation even of those famous orators had they not been writers as well?

The restraints which have been put upon the liberty of the press have been intended not only to prevent the diffusion of knowledge, and so to keep the community ignorant, weak, and obedient; they have aimed equally at preventing those who possess the gift of eloquence from exercising that gift, and obtaining thereby an influence which might endanger, if not upset, the existing distribution of power. The power which mere eloquence, unsupported by either 
superior sagacity or knowledge, is able to exert, is sufficiently evinced by the fact, that of all the products of the press, and especially of the periodical press, for one page that aims at enlightening the understanding, there are a hundred, of which the sole object is to stimulate to action by inflaming the imagination and rousing the passions, with very little regard either to fact or reason; and it is in this undeniable state of the case that the most plausible arguments have been found in favor of restrictions upon the liberty of the press.

\section{Section Seventh.}

\section{Virtue.}

The seventh and last of the primary elements of power is VIRTuE, - by which word we here intend, not those qualities, often so called, activity, courage, fortitude, policy, and perseverance hitherto enumerated, but Virtue in its proper moral sense, - that compound sentiment, which prompts to the performance of disinterested actions. But, in order to become an element of political power, this sentiment, not confining itself to mere private life, must be displayed under the form called Public Spirit, or Patriotism; that is, in conferring disinterested benefits on the community.

Hitherto this has been one of the weakest of all the elements of power; indeed, many have denied that it is an element of power at all. The sagacious and 
keen-sighted Machiavel remarks, that he who aims at power has no need of virtue itself, but only of the appearance of it; the appearance of virtue being a help, while the reality is a mere impediment. And there is a great deal of plausibility in this observation; for it is sufficiently certain, that while a reputation for virtue is, in many states, an essential element of power, and in all states a help, the actual possession of it proves often a great apparent stumbling block to the attainment of political eminence. But then there are two things to be considered; first, that sensible observation of Xenophon, in his Cyropædia, that the most certain means to obtain a reputation for virtue, is to be actually virtuous; and secondly, that what passes as political advancement is often not so much the actual obtaining and exercise of power, as it is the attaining of a certain official station and administrative dignity, - power at second hand, - by becoming the instrument of others; a sort of power at the best more like that influence which an adroit and supple servant may acquire over his master, and his master's underlings, than like the power possessed by the master himself. Compare, for instance, the power of Washington - one main support of which was virtue - with the power of the younger Pitt, or of Canning, both men of superior genius and great accomplishments, but who threw the sternness of virtue overboard as an impediment, and so rose, indeed, to the head of affairs; but only by becoming the conscious instruments of a bigoted aristocracy, which, in their secret hearts, they hated and despised, and by which they 
were constantly thwarted, whenever they desired to act in conformity to their own more liberal ideas. It will indeed often be found, that more actual power - influence, that is, over the progress of events is exerted, in free states, by those whose stubborn virtue prevents them from ever becoming heads of administration, than by those supple personages, who, under the names of chief magistrates, or prime ministers, are but the tools of a faction, a party, or a class. It has been no less well than wittily observed, that her majesty's opposition form a not less important and essential part of the machinery of the British government than her majesty's ministers. 


\section{CHAPTER III.}

SECONDARY ELEMENTS OF POWER, OR EXTRINSIC SOURCES OF INEQUALITY.

Section First.

Wealth.

So obvious is the connection between the distribution of power and the distribution of wealth, that the ingenious Harrington was led to maintain, in his Oceana, that Wealtu is the only just and true basis of power. That book, published in the last year of the English Commonwealth, undertook to show, that wealth had become so diffused in England, that monarchy could never be restored. But, as Hume has remarked, the falsehood of Harrington's assumptions, either as to facts or theory, or both, was abundantly proved by the quiet reëstablishment of the monarchy within that very year.

The circumstance, indeed, that political power is so generally used as a means of accumulating wealth, so that wealth and power are almost always found in company, has led to the idea of a more intimate relation between them than actually exists. Nor is there any more fruitful source of error, whether in philosophical inquiries or in the ordinary affairs of life, than the disposition to refer every effect to a single cause; whereas almost all the phenomena of human society result from a combination, and often a very complicated combination, of causes.' 'That wealth is 
one, and a very potent element of power, cannot be questioned; and yet history affords many instances in which power, having been originally founded upon something else, - as, for example, upon muscular strength, and military skill and combination, - and having, subsequently, been made a means of accumulating wealth, this very accumulation of wealth, tending in its operation to weaken the original basis of the power, has proved unable to supply the deficiency thus occasioned, so that a new revolution has been the consequence. What Sidonius Apollinaris writes of the Vandals in Africa, -

Spoliisque potitus

Immensis, robur luxu jam perdidit omne

Quo valuit dum pauper erat, -

Possessed of spoils immense,

Through luxury, the force was quickly lost, So potent in the poor, -

will equally apply to most of the barbarian invaders of the Roman empire.

It was, indeed, the perception of this operation of wealth upon some of the other sources of power, especially upon muscular strength and martial skill and endurance, which led many of the ancients to look upon the increase of wealth as a positive political evil. Even Machiavel was so struck with the superiority of the French, Swiss, and German troops a set of hardy barbarians, like the Cossacks of the present day - over the more civilized inhabitants of Italy, as displayed in the Italian wars of his time, that he was led to controvert the maxim which had become common in Italy, that money is the sinews of war, and to maintain that the true sinews of war 
were the sinews of men's arms. Yet modern experience serves to confirm the truth of the Italian maxim.

Why wealth is an element of power is sufficiently obvious. There are many things that cannot be done, or, more correctly, there are very few things that can be done, without a certain supply of the means of comfortably sustaining life, while the process is going on necessary to their accomplishment-a process which often demands, through a protracted périod, the most devoted and undivided attention. A certain degree of leisure, of freedom from the constantly-pressing necessity of daily labor to provide for daily wants, is essential to afford an opportunity for the primary elements of power to come into play. Besides, there are comparatively few things which can be accomplished by the mere unassisted faculties of man. Tools to operate with, and materials to operate upon, are necessary; and the possession of these is wealth. So much for the connection between wealth and power in general. The connection between wealth and political power - that is, power over other men - is not less obvious. He who possesses the means of conferring pleasures, or inflicting pains, upon others, possesses a power over them proportioned to the potency of those means. Thus the rich are able to purchase up, and to appropriate to their own use, the assistance and service of strength, dexterity, sagacity, knowledge, eloquence, in fact, every one of the primary elements of power except virtue, and if not that, the appearance of it, which many times answers the same purpose. And 
in addition to this process of aggregation, the nature and operation of which will be more fully explained hereafter, the rich, also, from the comparative smallness of their number, and for other reasons, possess great facilities for combination, which, as we shall presently see, is another of the secondary elements of power.

There is still anotherway in which wealth operates, to no inconsiderable extent, to procure or to corroborate political power; and that is, by exciting in the minds of the multitude, by a judicious display, agreeable feelings, compounded of admiration and of those pleasures arising from the perception of the beautiful and the harmonious, intermingled with that moral pleasure which arises from the contemplation of the polite and decorous, the lesser morality ; which compound pleasure the subject class derive from contemplating, at a distance and at intervals, the splendid and polished life of their superiors. Hence the shows and formalities of courts, and that pomp of dresses, equipage, and ceremonials, regarded, and not without reason, as a potent means of influencing and ruling mankind. This, surely, is one of the most innocent means of augmenting power, since it confers no inconsiderable amount of pleasure upon the admiring multitude; but, unfortunately, it happens that the admiring multitude seldom enjoys this pleasure of admiration for nothing, being made to pay for it, not only an equivalent in submission, but too often an equivalent of money also, since such shows are commonly exhibited at the public expense.

It would seem, then, that wealth must always tend 
to increase, in certain very important particulars, the political power of its possessors. When it operates to diminish their power, that operation is always indirect, through the tendency of wealth, after the accumulation of it has passed a certain limit, to diminish, by the indulgences of which it furnishes the means, the strength, skill, and self-control, and even the sagacity, knowledge, and virtue, but especially the activity, courage, perseverance, and fortitude, of those who possess it.

This operation is very remarkable, and is worthy of particular attention. All the other sources of power combine and play, as it were, into each other's hands. But when to all these sources of power great wealth is added, - all those other sources being employed as means to accumulate wealth, - that very wealth, thus accumulated, by the indolence and luxury to which it leads, sooner or later weakens and undermines all the other sources of power, and thus, by an. operation the least expected, often produces political revolutions.

This consideration, duly weighed, ought surely to diminish the rapacity of the ruling classes - a rapacity which tends doubly to revolution; first, by exciting violent pains of inferiority and disappointment, if not pains of hunger and disease, and along with them a high degree of malevolence in the subject class; and secondly, by producing a concentration of wealth in the hands of the ruling class, which, in the end, produces, as to them, a great diminution of the primary intrinsic elements of power, thus sacrificing the substance to the shadow. 
Section Second.

\section{Traditionary Respect.}

Where a father, from any cause, has been in possession of a high degree of power, by that law of the association of ideas which may be called the law of contiguity, men are led to expect the same qualities in his child; and, till experience prove the contrary, - and often, indeed, in spite of experience, - to give the child credit for possessing them ; an association which becomes stronger as the period increases during which power has been in the family. There is commonly, also, a certain external resemblance between fathers and children, and, indeed, between ancestors and descendants much more remote; and that law of the association of ideas, which may be called the law of resemblance, leads us to expect a resemblance in other particulars also. Moreover, the child, growing up under the roof of its father, and being its father's well beloved, shares, from infancy, some portion of . that admiration and respect which belong to the father; so that the habit of respect and admiration becomes established long before it appears whether there is any just foundation for them or not. Upon this basis rests the influence of family, blood, descent; an influence which has operated, and which still operates, to a very considerable extent, even in communities reckoned the most democratic. 


\section{Section Third.}

\section{The Idea of Property in Power.}

Property has been most ingeniously, and at the same time justly, defined by Bentham as merely a basis of expectation - the expectation of deriving certain advantages from a thing which we are said to possess in consequence of the relation in which we stand towards it; the idea of property consisting, not in any mere circumstances of physical control, which may be present or absent, - but in the persuasion of being able to draw such or such an advantage from the thing in question, according to its nature. Now, this idea of property - this expectation - is just as able to attach itself to political power as to any thing else. Where the exercise of power has, for any length of time, become fixed in the hands of certain families, or in those of a particular caste, or in the possessors of certain landed or other property, or even in the mere members of a certain party or religious sect, there soon springs up an expectation that this order of things will be continued. Those who have the qualification of birth, or property, or party connection, soon come to look upon office as their freehold, the possession of power as their moral right, and obedience as the moral duty of the subject class; and this opinion is often adopted by, and exercises a powerful influence over, the subject class itself. It is doubtless true, that property in power is a sort of property detrimental to the community, and which ought not to be allowed 
to exist. But the same is true of property in slaves, which, however, is a kind of property which has had an existence almost universal, and which still continues to be very generally recognized.

Section Fourth.

Influence of Mystical Ideas.

WE come now to the consideration of an element of power very much overlooked by writers upon politics, but which has exercised, nevertheless, an influence more potent and extensive, perhaps, than any, if not than all others.

In a community in which mystical ideas prevail, and as they spring from obvious sources innate in - man, their prevalence is universal, - if any individual can succeed in persuading the rest that he is the chosen favorite and selected messenger of the Deity, it is evident that he will at once be raised to a position of infinite superiority over them, since to his other titles to power he is able to add, at least in the opinion of his associates, - an opinion, for all practical purposes, equivalent to reality, - all the attributes of Deity itself. What more calculated to subdue at once, by the combined operation of admiration and fear, all opposition? Those governments which have exercised the most unlimited authority have all been theocracies - governments, that is, of which the administrators claimed to be the special favorites, and representatives, and chosen vicegerents of the Deity; among which number are to be reckoned 
some of the most splendid empires which the world has seen.

With respect to the founders of theocratic empires, and others, who, without founding empires, rise, by similar means, to a greater or less degree of power of which the instances are innumerable, the hypothesis, which has been maintained by some writers, of pure hypocrisy and imposture on their part, (as in the noted instances of Mohammed and Cromwell,) is utterly untenable. The well-known maxim of Horace, that he who would move others must first be moved himself, is perfectly applicable to these cases. For a man to be able to impress others to any extent with the idea that he has received a special divine commission to command, direct, and teach, it is essential that he should first persuade himself of the same thing; which easily happens whenever an unhesitating and zealous reception of the mystic hypothesis is united to a lively imagination, a contemplative disposition, and the influence of the sentiment of selfcomparison, operating in an extraordinary degree upon souls to whom the paths of secular ambition do not lie open. Tacitus has set forth the true character of this remarkable class of men in three words: Fingunt simul creduntque - they feign and believe simultaneously. To impress their pretended revelations upon others, mere asseveration will not suffice. They must themselves set the example of implicit belief in their own inventions - an example pretty sure to be efficacious, since there is nothing more contagious than credulity. Belief, in such cases, is, indeed, seldom or never an act of reason. So great is sometimes the fear, and sometimes the admiration, but oftener both, excited 
in susceptible minds by the suggestion or contemplation of ideas adapted to affect them, that these excited emotions prompt at once to headlong action, without leaving time, capacity, or disposition to distinguish between facts and chimeras. In such cases, the bare suggestion of a doubt is resented as an injury, by those who imagine, themselves the possessors of a wonderful discovery, a special divine communication, which elevates those intrusted with it into a superior order - a spiritual aristocracy.

This sincerity, however, - this belief in their own divine mission, - on the part of these mystic leaders, so far from preventing the frequent employment, on their part, of craft, downright falsehood, and presently of force, so soon as they are in a position to resort to it, justifies, in their view, the use of any means whatever which may seem necessary for the accomplishment of their purposes. He who considers himself the special agent and selected vicegerent of the Deity, and not only so, but himself able to control, at least to a certain extent, the divine actions, - for to that full length go the commonly-received notions among all nations of the efficacy and power of prayer, - any person possessed of these notions, and educated in that mystical theory of morals so generally prevalent, which makes the divine pleasure the foundation of all moral distinctions, very easily imagines his own will and that of the Deity to be the same, and very easily substitutes his own will, under the idea of its being the divine will, as the true foundation and actual test, for the time being, of right and wrong. Hence the power which all these mystical leaders have, to a greater or less degree, assumed of forgiving sins, 
dispensing with the moral law, and of relieving from the obligation of oaths and promises.

We may observe, however, of mysticism, as of all the other secondary elements of power, that being essentially secondary in its operation, in order to become of any consequence in politics, it must be conjoined with those primary elements - activity, courage, fortitude, policy, and perseverance. Disjoined from these qualities, mysticism subsides into a mere dreamy, idle, contemplative state, changing men into hermits and devotees, absorbed in prostrate and humble adoration, without the hope, or, indeed, the wish, of affecting, in the slightest degree, the course of events, regarded by the mystic hypothesis as immediate and inevitable emanations from the divine will, which men, more inclined to reflect than to act, absorbed in admiration and awe, are too reasonably humble to presume to wish to control.

It is worthy of observation, also, that mystical founders of new sects and empires very seldom call upon their followers to disbelieve any thing. What they ask of their converts is, not to believe less, but to believe more. It was thus that Mohammed admitted the truth of both Judaism and Christianity, and to a certain extent, also, of that system of paganism which prevailed throughout Arabia prior to his time. Nor have Protestant critics failed to point out how the corrupt Papal church gradually absorbed and recognized all the preëxisting creeds of the various countries and nations to which Christianity spread. There seems, indeed, to be very little doubt that the Orthodox view of the mystery of the Trinity, as finally settled by the decisions of the earlier general councils, 
took its origin with speculatists who regarded Plato with little, if any, less reverence than Christ; and it still remains a curious object of historical research, how far the doctrine of the incarnation is to be traced to the influence of Buddhist missionaries, who, at or before the Christian era, appear to have penetrated towards Europe, as well as into China. What is more certain is, that, as the Christian religion spread through the Roman provinces, it not only adopted a large part of the pagan ceremonies, converting the pagan festivals into saint days, but that it admitted the whole heathen mythology, with the trifling modification, that the heathen gods were not gods, but only demons, or devils; the famous Magian doctrine of the two principles being thus employed to reconcile the pagan and Christian creeds - an idea, of which Milton admirably availed himself, first in his Christmas Hymn, and afterwards more elaborately in the first book of Paradise Lost.

As the Christian religion spread among the German and Celtic tribes, it adopted also a large part of their mythology; and among the northern nations, at least, the doctrine of witchcraft and of fairies, derived from those sources, became so ingrafted into the Christian faith, that to ridicule or to deny the existence of witches was looked upon, down to a very recent period, as little better than atheism.

In like manner, in later times, those who have attempted to establish new views in religion in those countries in which the Christian doctrine is generally received, as in Great Britain, Germany, and America, have admitted the supernatural origin of Christianity, and built upon it-as the Quakers, the Moravians, 
the Swedenborgians, the Shakers, the Irvingites, the Mormons. In modern France, where Christianity among the educated has, in a measure, died out, the new sects, such as the St. Simonians, have attempted to build upon the prevailing system of Deism.

Mystical ideas, in their influence upon politics, present themselves under three very distinct forms. First, as Superstition, that influence of mysticism which keeps those under it in a state of abject, unquestioning, willing submission, at the feet of those claiming to be God's vicegerents. Secondly, as Bigotry, the influence of mystical ideas over those whose superiority rests upon them-an influence which makes them look with fear and hatred upon every thing which has a tendency to diminish the power of those ideas. Thirdly, as Fanaticism, that influence of mystical ideas which, in leading men to believe that they themselves have received a special and peculiar inspiration and commission from the Deity, induces them to set up first as religious reformers, teachers, and messengers of Heaven, and presently as founders of theocracies - for, wherever the least opening for it appears, there is seldom a failure to act upon the doctrine that the saints shall inherit the earth. Though in some points very divergent, and even hostile, yet all these operations of mystical ideas are also more or less coincident, and very easily run into each other.

But if mysticism has been one of the greatest sources of inequality among men, - greater, indeed, we may say, than all the other secondary elements of power combined, - and, in consequence, one of the chief supports of government, it has also been, 
from that same circumstance, one of the most tremendous agents of revolution. So long as there exists a coincidence or harmony between the religious and the political heads of a nation, superstition and bigotry are the firmest supports of the government; and even fanaticism sometimes, as in the case - to a partial extent at least-of the founders of the mendicant orders in the Romish church, and of the Society of the Jesuits, may lend its powerful aid to the same side. But whenever, from any cause, this harmony is destroyed, whether by changes of opinion taking place on the part of the governors or of the governed, superstition, bigotry, and fanaticism become alike the most dangerous enemies of those in power. Thus we can easily understand how the English High Church party are such violent denouncers in Ireland of superstition and bigotry, and at the same time such zealous promoters of them in England; and also how it happens, in English history, that almost all of the enthusiasts in religion have been of the liberal party in politics. Hence, also, we may see why it is, that states governed theocratically, although the power of the governors and the submission of the governed be most unlimited, are still liable to sudden and violent revolutions. For the mystical ideas upon which the political and social institutions of such states rest may, at any time, assume a fanatical operation, - as frequently happens in Mohammedan states, - and so may produce an entire reconstruction of the whole political fabric. 


\section{Section Fifth.}

\section{Combination.}

There remain to be considered two other elements of power, which may be regarded as secondary, not only in respect to those which we have classed as primary, but also in regard to the four secondary elements already enumerated. These are Combinstion and AgGregation, by means of which a smaller united force, acting under onc head and guidance, is able to overcome a far larger force, dispersed, uncombined, and acting without concert. It is by virtue of these principles that a small band of soldiers, drilled, disciplined, and acting together, is able to keep under a vastly greater body of men dispersed, and without mutual understanding or coöperation.

The increase of force gained by combination will enable us to understand why so many despotic governments take such extraordinary means to prevent and suppress combinations among their subjects; whence have originated laws against the right of petition, laws against public assemblies, laws against associations, and a portion of the laws in restraint of the liberty of the press.

A petition to the governing authority, setting forth alleged grievances and praying for redress, is not only an appeal to the moral sentiment of the governors, it is also a method of combination, a means of exhibiting the numerical force of the petitioners, and of making their strength known to each other, as well as to the government. Where the petitioners are very 
numerous, what is a petition in form may assume, in fact, the character of a rally or a threat. This is the reason why, at times, the right of petition has been denied or resisted, and why attempts have been made to suppress it by law. So long as petitions come from one only, or a few, no government ever makes any attempt to suppress the right; on the other hand, it is rather encouraged, those who possess the political authority making a sort of ostentatious exhibition of their readiness to listen to complaints. It is only when the petitioners are numerous, when it becomes evident that there are a large number combined and acting together, that those in authority take the alarm, and attempt to defeat or abridge this privilege. The conduct of the English House of Commons, respecting petitions for parliamentary reform, in 1817 and 1818, and that of the American Congress, in 1835 and subsequently, respecting petitions for the abolition of slavery in the District of Columbia, afford illustrations of this fact.

Much more formidable than petitions, however numerously signed, are assemblies of the people, held for the discussion of political topics. Great masses of men, thus brought together, may perhaps break out into sudden rebellion, and may employ their combined strength for the overthrow of the government. Such musters of the popular militia tend strongly to remind the people of their strength, and may prove more than a match for the standing army of the constituted authorities.

Organized political associations are even more formidable than public meetings, because in this way a regular plan may be matured, and all the means 
may be arranged and provided, for transferring the authority of government into new hands. The experience of the last sixty years has shown very fully how much may be accomplished by the combined force of affiliated clubs and organized associations. We need not wonder, therefore, at the extreme jealousy with which, in all despotic governments, all such combinations are regarded, and have been suppressed, from the period of the Roman empire downward.

The liberty of the press on political topics, besides the other purposes which it serves, is also a grand means of political organization. It affords a medium whereby those having common interests and sympathies may, however scattered and separated, keep up a constant communication with each other. A newspaper is a sort of speaking trumpet, whereby the leaders of a party communicate with their followers; directing them how to act, and stimulating their zeal and courage by constant exhortations. This circumstance alone would be sufficient to explain the fierce hostility of so many governments to the liberty of the press.

Of the effect of combination a striking instance is afforded by the "caucus system" of America. No doubt something of the same sort has existed in most democratic governments; but, owing to the large scale on which elections are held in America, (a wide extent of territory and a large population participating often in the choice of a single officer,) it has attained there a special development. Though, by an approach to universal suffrage hardly to be paralleled elsewhere, almost the entire free adult male popu- 
lation of the United States possesses the right, and nominally the equal right, to participate in the choice of legislators and magistrates, yet that selection, by a process wholly unknown to the written law, though none the less on that account a part of the system as it exists in practice, is in fact substantially determined by a very limited number. The designation of candidates for office, whether municipal, state, or national, is assumed by certain voluntary affiliated associations, under the name of parties, as many generally as there are considerable portions of the people, taking different view of the public interest; and it is only by joining and acting with one of these parties, and as the candidate of it, that any body can hope to be elected to any office. These parties are led and managed, in fact constituted, by a small number of men, commonly known as politicians, who feel, or at least who profess, a special concern in the public welfare, which, in general, they are not at all indisposed to promote by serving the public themselves in stations of honor and profit. There are, indeed, among these politicians by profession, a large number of pure mercenaries, ready to act with any party that will give them office, and anxious only to discover and to attach themselves to the strongest side, upon which side, of course, the larger part of them may be expected to be found. Each of these parties has its nominating committees, or conventions, - township, city, county, district, state, and national, - appointed, according to certain unwritten "party usages," by primary meetings commonly known as caucuses, which, however, are composed in general only of the more active politicians, and the action of which is 
chiefly determined by the secret contrivance and management of a still smaller number. In the constitution of these committees, the grossest frauds, and even open violence, are occasionally employed; especially where, by the predominancy of the party which it represents, the committee has many lucrative offices at its disposal-usurpations which it is not uncommon for parties in America to submit to, as quietly and coolly as have the French people to the usurpations of the Bonapartes, and, for the sake of peace, and union against a rival faction, to confirm them too, in like manner, by their votes.

By committees, or caucuses, thus constituted, all nominations to office are made; all that is left to the body of the citizens being the choice between generally not more than two individuals, neither of whom, as it often happens, would, apart from this preliminary nomination, have any special hold on the electors.

The caucus system thus becomes a contrivance for the distribution of offices among men more distinguished for intrigue than for talent, who, by mutual combination and support, and by serving each other's turns, are often raised to elevations, sometimes very high ones, to which, by their own unassisted efforts, they could scarcely have attained.

Yet, while these caucus politicians thus take upon themselves the aristocratical function of dictating to the people, they play, at the same time, a democratic part, by humbling and restraining within due limits those possessors of the natural elements of power, whom the strong tendency to "hero worship," even in the most democratic communities, might otherwise be likely to elevate to a dangerous authority. 
So potent, however, are the natural elements of power, that even these caucus combinations are obliged to respect them, being not only made to feel the force of them in their own internal constitution and procedures, but in their nominations, also, to pay a certain respect to that inevitable admiration with which the body of the people always regard men of superior endowments, real or reputed.

\section{Section Sixth.}

\section{Aggregation.}

WHERE there is a voluntary union of strength for the accomplishment of a common object, we call it Combination. Aggregation is an element of power similar in its nature and effect, and still more general in its operation and influence, but differing in one important particular.

In the case of combination, the parties stand upon a certain level of equality, or something approaching towards it, the combination being on their part a thing more or less voluntary, and for the mutual benefit of all the parties to it. Aggregation is where one, or a number of individuals, having established an influence and control over others, more or less complete, through the agency of the other elements of power, or some of them, are able, by means of that influence and control, to use the strength of those others as if it were their own, and to employ it in giving to their influence and control a still further extension. By this aggregation of power, one single 
individual - as in the case of Napoleon Bonaparte may come to control an entire community, nay, a vast empire. Power has indeed a tendency to increase in a triplicate ratio. As it becomes greater, not only does it inspire the greater dread in those who might otherwise be inclined to resist it, but the admiration it excites and the favors it can confer both increase in the same proportion. So much indeed is the multitude disposed to admiration and reverence, so profound is the worship paid to power, that we need not wonder that some conquerors and others have been persuaded, by the abject devotedness exhibited in their service, to regard themselves as children of destiny, sons of God, indeed as themselves gods.

\section{Section Seventir.}

Illustration from the Iliad.

The poem of the Iliad presents quite a complete illustration of the operation of all the elements of power, - both the primary and the secondary, - being in this respect no less true to nature than in so many others.

Activity, courage, fortitude, and perseverance are qualities common, in a greater or less degree, to all the heroes of that poem. They all also owe a part of their consequence to traditionary respect, to the idea of property in power, and to the influence of mystical ideas; for they are not only chieftains by descent, but are descended from the gods, who still remain interested in their welfare. Ajax personifies 
bodily strength and courage; Achilles, strength, courage, dexterity in the use of arms, and force of will ; Ulysses, sagacity, policy, and eloquence ; Nestor, eloquence, sagacity, and knowledge ; Agamemnon, wealth and traditional respect in a particular degree; Hector, patriotic virtue. The union and disunion of the chiefs exhibit the effects of combination; while their individual consequence at the same time depends, not merely upon their personal character, but upon the aggregation of power, the number of men and ships, which the extent of their several dominions places respectively at their disposal. 


\section{PART SECOND.}

FORMS OF GOVERNMENT AND POLITICAL REVOLUTIONS.

\section{CHAPTER I.}

COMMENCEMENT OF ORGANIZED GOVERNMENT.

\section{Section First.}

Communities in which there is no Organized Government.

There are many communities, small and savage, - an aggregation of families which live and hunt or fish together, - in which government, under any organized form, can be hardly said to exist. The . authority of each man over his family is well established and perfectly definite; but there is no general authority. Each family protects its own persons or property; except when aggressions come from some other tribe or community, when all unite for the common defence. The women are held in a condition of servitude; but among the men a high degree of equality prevails, and, if this community enjoy the advantage of a genial climate and abundance of game, a considerable degree of ease and comfort also; such a degree, in fact, of equality, 
ease, and comfort, especially of equality, when, compared with the condition of the great mass of the people in highly-civilized states, as has deeply impressed the minds of many speculative inquirers, who have thus been led to doubt whether, after all, civilization, as compared with this, which they have denominated the state of nature, is really favorable to the happiness of mankind.

In such a community, when any matter occurs interesting to the whole, such as the proposal of a hunting excursion, a migration, or a military expedition, all the men meet together to talk it over. But whatever decision is come to, it is only binding upon those who assent to it. The dissentients are not bound. There is no general authority constraining individuals, whether they will or no.

The non-existence of an organized government in such communities is evidently owing to the high degree of equality among the adult male members of it, which prevents any individual, or number of individuals, from attaining a decided leadership or control, at the same time that it induces a general respect for, or, more properly speaking, an indisposition to violate, the rights of each other; because such violation would certainly be resisted, and perhaps severely revenged; so that the same cause which prevents government from being established prevents the want of it from being felt. In such communities, the accumulation of wealth is almost unknown. Property exists only in a few articles of daily use, and being very equally shared, all those temptations to inflict injuries upon others, which grow out of the accumulation of wealth, are also unknown; and in 
the ratio that opportunities for injurious exertions of power are less frequent, in the same ratio is there the less occasion for remedial exertions of power.

But this equilibrium, in which the forces not only counterbalance but nullify each other, is, except in the fancy of political romancers, never perfect. The old men, by reason of their superior knowledge, the fruit of experience, - sole source of knowledge in such a community, - exercise a certain controlling influence over the rest. Those who, by nature's endowment, or by practice and exercise, possess a superior degree of strength, dexterity, sagacity, activity, perseverance, fortitude, self-control, and disinterestedness, attain also a degree of in- . fluence. Even among the most barbarous tribes, eloquence becomes a source of power, the orator enjoying a distinction next to that of the eminent huntsman and warrior.

\section{Section Second.}

Causes which lead to the Establishment of an Organized Government - War.

When a community, such as that above described, has no neighbors, or remains, for the most part, at peace with them, or attains no new ideas, this nonexistence of an organized government may continue for an indefinite period. There are, however, three causes, which may come into operation at any time; each potent enough - by bringing into play one of the secondary elements of power - in itself to give rise to the establishment of regular anthority; and all 
three of which frequently combine to the same end. These causes are, first, $W_{A R}$, to which a degree of combination if not of aggregation is essential; second, Accumulation of Wealti ; third, Influence of Mystical Ideas.

Every war expedition consists of combined strength. It must also have leaders in whom power is aggregated, and, to be conducted with success, a single and supreme leader. Before organized governments are fully established, any warrior distinguished by his strength, skill, sagacity, activity, and courage, and strongly impelled by the love of authority and distinction, proposes himself as a leader, and sets out with such followers as choose to accompany him. Such seems to have been the state of things among the German tribes described by Tacitus, and such is still the case in many of the aboriginal communities of America. Where war has become habitual, as seems to be the case with most of the African tribes, this leadership acquires a more regular and permanent character, and the authority of the head war chief and his subordinates becomes firmly established and universally recognized. If, in intervals of peace, that authority remains quiescent, it is because peace, in a tribe in which there is no accumulation of wealth, affords little occasion or opportunity for the exercise of authority. 
COMMENCEMENT OF ORGANIZED GOVERNMENT. 75

Section Third.

Accumulation of Wealth.

There is no community, however rude and poor, in which the idea of property is not as fully established as in the most refined society. Every where, even the most completely savage expect to derive a special and individual advantage from the bows and arrows they have made, the huts they have built, the canoes they have laboriously hollowed out or ingeniously fabricated, the fruits they have gathered, the beasts they have slain, the furs they have dressed, and the roots or grain they have planted. It is this expectation of advantage in which, as we have seen, the idea of property consists - an expectation not arising merely from convention, as many have alleged, and therefore solely created by law, nor founded merely upon strength and art exerted to maintain an actual possession, as others have argued, but to a great degree, based, also, on the ordinary force of the moral sentiment restraining men from the unprovoked infliction upon others of the pain of disappointed expectation.

So long, in fact, as property is limited to the objects above enumerated, the temptations to plunder are, in general, so slight, that, as between members of the same tribe, they are sufficiently repressed by this sentiment of benevolence, or, where that fails, by the fear of that resistance to robbery which every man is able to make for himself. The relations of property, in such a state of society, are, in general, far from 
complicated. For the most part, things are in the actual possession of those to whom they belong; and the $x$ rint of the possessor is generally so clear as to give few occasions for dispute. Thus, during peace, there is littlë p̈recience or spuortunity for the exercise of authority, which circumstance sufficiently explains why it is that, in such communities, the existence of regular authority becomes evident only during war.

But when such a community advances from the hunter to the pastoral or agricultural state, the necessity is felt of a distribution or allotment of land, permanent or periodical; and, simultaneously, the need of some authority to maintain that allotment, and of some arbiter to settle disputes. The accumulation of wealth, in consequence of these new exercises of industry, tempts, also, more and more to violations of the rights of property, not only by offering new and seducing objects of plunder, but by now first giving origin to the desire to accumulate. Under these circumstances, the necessity for some civil authority becomes obvious; and no sooner does the opportunity of exercising such authority present itself, than it is immediately availed of by the chiefs, who, from being leaders in war, become now also judges and magistrates in peace. The final settlement of controversies, no less than the leadership of warlike enterprises, demands a sovereign authority; and as the bravest, most sagacious, and enterprising of the warriors becomes the war leader, so one and generally the same chief rises to the head of civil affairs.

For some time, this chieftaincy remains open to be assumed by him whose ambition prompts him to take 
it, and whose ability enables him to keep it. But gradually traditional respect and the idea of property in power supervene, and fix in a single family the headship of the tribe, which begins to descend from father to son; or when, as is frequently the case among savage tribes, the descent is through the female line, from the uncle to the nephew; liable, however, to constant interruptions whenever the heir is an infant or an imbecile.

Such is the simplest form of monarchy; and, generally speaking, until this form be reached, an organized government can hardly be said to exist. Such was the form which prevailed among the Greeks previous to the introduction of republicanism, in the times when the Iliad and Odyssey were composed, and more recently among the Scotch and Irish clans. Under this form, the whole authority - judicial, under which the legislative is also included, and executiveis vested in a single chief, at once judge, legislator, and himself often executioner also. But his power is very far from despotic; the inequality in such communities between the chief and the clansmen does not yet reach a very high degree; and his authority can only be maintained by a general conformity, in the exercise of it, to the ideas of the governed. Should the chief attempt to act in decided opposition to those ideas, he would soon find himself deposed from his office, which would, in general, be conferred upon some other member of the ruling family. Not unfrequently, however, in such cases, the chieftaincy is transferred to some new family; or, if matters are ripe for it, the form of government is changed, and monarchy ceases. The consciousness of his own weakness operates, in 
such governments, to keep the chief within certain bounds; and the consciousness of their own power still preserves to the clansmen a bold and manly bearing.

Section Fourth.

Infuence of Mystical Ideas.

WE may, however, frequently observe, among communities no further advanced in civilization than the Grecian, Scottish, and Irish clans above referred to, (as, for instance, among the inhabitants of the Sandwich Islands and other islands of the Pacific, as they appeared to the discoverers a century or less ago, and among some of the savage American tribes,) the existence of a government perfectly despotic, of which the origin is to be sought and found in the influence of mystical ideas. These ideas, under one form or another, exist among all savage tribes; nor are there often wanting individuals, at once visionary and fond of superiority, in whom the twin spirits of credulity and imposture are mingled in such degrees as to fit them for claiming a special knowledge of spiritual matters, and even an intercourse and an influence with supernatural beings. In all savage and barbarous tribes, persons of this description, known among the North American Indians as "powwows" or "medicine men," and among the Africans as "obeah men," exert an influence greater or less, and contend for power with the chiefs, whose authority is founded upon the forensic basis above pointed out; and occasionally it happens that some one of them succeeds 
in establishing so firmly the belief in his supernatural power as to be able to subject his whole tribe to implicit submission - of which a remarkable, and, in the United States, familiar, instance occurred less than half a century ago, in the ascendency established over the Indian tribes north-west of the Ohio by the celebrated Shawanese prophet.

It is in this influence of mystical ideas that we must seek for the origin of the Mexican and Peruvian empires in America, presenting, in the abject servitude of the mass of the people, so marked a contrast to the free spirit and general equality prevailing among the greater part of the American aborigines. The theocratic governments of the old world - those of Egypt, Gaul, India, and Central Asia - no doubt arose from similar beginnings. We have authentic historical proof that such was the origin of the splendid empire of the caliphs, and of the theocratic states of Christendom, the Popedom included.

Despotic authority, thus established upon a mystical basis, proves very effectual in subduing the violence and indolence of barbarous and savage tribes, and for introducing among them a regular and settled industry. This was strikingly exhibited in the Jesuit settlements in Paraguay, and in the missions among the wild Indians (Indios bravos) of Central America, and of the north-western provinces of Mexico; and the same effect has been produced, though much less strikingly, by the Protestant, especially the Moravian, missions among the American aborigines.

This influence of mystical ideas, as there will be occasion hereafter to show more at length, exists 
with very different degrees of intensity in different communities. It is frequently intermingled, to a certain extent, with the other elements of power, the chieftains being priests by virtue of their office, and often claiming a descent from the gods. Governments founded, in whole or in part, upon this influence, like those founded upon a purely forensic basis, always assume, in the first instance, a monarchical form. In proportion as the mystical element becomes more predominating, they take on a more despotic character ; the obedience of the subjects becoming, at the same time, the more unhesitating and entire. 
DEVELOPMENT OF THE ORIGINAL MONARCHY. 81

\section{CHAPTER II.}

\section{DEVELOPMENT AND GROWTH OF THE ORIGINAL MONARCHY.}

\section{Section First.}

Limited Extent of the Embryo Monarchy.

ThE original monarchy, whether mystical or forensic, is, in its embryo state, very limited in extent, a mere chieftaincy, embracing only one of those small tribes . or clans into which we always find men in the hunter state divided, that method of life not allowing the living together in considerable numbers. Nor, so long as men remain in the hunter state, does this embryo monarchy admit of any enlargement, beyond a recognition of his superior authority, which some chieftain more energetic than his neighbors may obtain from a number of neighboring clans, which are thus united into a confederacy, of which he is acknowledged as the head. Such was the state of things among the aboriginal inhabitants of America, (those of the great tropical plateaus excepted,) whose largest tribes hardly embraced more than three or four thousand persons ; and whose most potent confederacies, though often occupying territories not inferior in extent to the British Islands, could not count more than twenty or thirty thousand. 


\section{Section Second.}

Passage from the Hunter to the Shepherd State. Commencement of the accumulation of Wealth.

ON those broad steppes, savannas, prairies, which compose so considerable a portion of the surface of the globe, and which are so well adapted to the support of graminivorous animals, - the diminished supply of wild game no longer affording sufficient food, - men have been driven; or, finding that method more convenient and certain, have been thence led to adopt the breeding of certain animals found capable of domestication. Changed thus from hunters to shepherds, these tribes become masters of large herds of cattle, sheep, goats, horses, asses, camels, some or all of them, according to the nature and climate of the country which they inhabit. These animals, thus domesticated and appropriated, constitute wealth, a thing unknown in the savage state; and the introduction of this new element does not fail to be attended with important results, as well social as political.

\section{Section Third.}

\section{First Effect of this Change - Increase of Paternal Authority.}

The hunter, as we have already seen, has no means of influence over his children, or over any body else, beyond those which he derives from his superiority 
in the intrinsic elements of power; and in such a state of things, the father's control over his male children naturally ceases when they attain to maturity. But the accumulation of wealth introduces a new element. The shepherd father possesses in his flocks and herds, and in his power of regulating the distribution of them among his children, either during his life or at his death, a new means of controlling their actions, and of keeping them obedient to his wishes. The shepherd father also has the means - which the hunter father has not - of employing the services of his children, even during their early youth, in a manner profitable to himself, since these children can be made useful as herdsmen and shepherds. Among hunter tribes, the authority of the father over his male children is very limited; nor does he often, as has already been observed, attempt to employ their services for his own benefit. In shepherd tribes, the children are subjected to a severer discipline. The character of master begins to intermingle itself with that of father. The father's power of life and death over his children, which is limited in hunter tribes to the very young, is thus often protracted among pastoral nations to the whole period of the father's life. It is too in this condition of society - as among the Arabian and Celtic clans - that genealogical considerations naturally acquire a new degree of force. Thus the chieftain often claims to represent - as perhaps in fact he sometimes does - the original remote ancestor of the whole community. 
Section Fourth.

Second Effect - Introduction of Domestic or Chattel Slavery.

Wirm the accumulation of wealth, and the desire to extend that accumulation, labor begins to acquire an exchangeable value. The prisoners taken in war, especially the women and children, more manageable than the men, instead of being murdered, and perhaps eaten, or else adopted to supply the place of lost relatives, or to replenish the scanty population of the victor tribe, begin now to be made slaves of, and to have a certain value as such. Hence a new stimulus to warlike enterprises. The hope of plunder added to the impulses which drive hunters to fight, shepherd tribes become far more pugnacious than they.

Domestic slavery, in this its original form, is comparatively mild. Those slaves, especially, born in their master's house, stand almost on a level with his children, which indeed they often are - the female slaves serving as concubines to the master; nor in general, in this primitive condition of society, is there any hesitancy in acknowledging this relationship. 


\section{Section Fifth.}

Third Effect - Introduction of Organized Government.

THis accumulation of wealth in herds and slaves, while it tends to increase the power of the father of the family, tends also to increase the power of the chieftain of the tribe. It has already been shown how the accumulation of wealth creates occasion and gives opportunity for the exercise of authority, as well during peace as during war; and how he who was at first leader only in war becomes also during peace judge and arbiter for the settlement of disputes, and executioner for the punishment of wrong doers; a permanent and regularly-organized government thus taking its first establishment.

Though the pastoral state has, in several respects, great advantages over the hunter state, admitting a great increase in the number and concentration of the community, yet it falls, in these respects, far below the agricultural state; nor do purely pastoral tribes ever pass the limit of barbarism. Whenever the rulers of pastoral empires have attained to a certain external splendor and luxury, this will always be found to have been due to their conquests over agricultural tribes. 


\section{Section Sixth.}

\section{Extension given by Agriculture to Chattel Slavery.}

The life of the shepherd is very analogous, in many respects, to that of the hunter; nor does the transition from the hunter to the shepherd state seem very difficult. But to convert either a hunter or a shepherd into an agriculturist is a more difficult matter; for agriculture requires a diligent and continuous application, of which men are incapable unless they be trained to it from early youth, or be goaded to it by some impulse of peculiar force.

We may observe that the labors of agriculture, in its earliest rudimentary form, as it appears among savage nations, are confined to the women, who are in fact slaves. When any of the shepherd tribes - by a change in their location or other causes - have found it expedient to add agriculture to the keeping of flocks, this agricultural labor has been principally carried on by slaves, who, with this change of occupation, begin to feel all the severities of servitude.

From the first dawn of history, till within a comparatively recent period, the soil of Europe has been cultivated - when cultivated at all - almost entirely by slaves or serfs; and in consequence, operative agriculture always has been, and in fact still is, considered an occupation not less degrading than laborious. The alleged honor paid to agriculture among the Romans may be cited in opposition to this statement; but that honor - if it was ever paid to operative agriculture, which is sufficiently doubtful 
- was paid to it only while the Romans still continued very poor. So soon as they possessed themselves of slaves, agriculture became a servile employment; and in the days of Roman power and splendor, the whole, even of Italy itself, was tilled by servile hands. Agriculture among the Romans, as now among the English, was esteemed honorable, not to those who held the plough, but to the owners of the land, who at the utmost only superintended the labors of others. The epithet plougliman, respectable as it ought to be, is, by the usage of the English language, a contemptuous synonyme for a stupid and illiterate booby.

\section{Section Seventh.}

Influence of Mystical Ideas a Substitute for Chattel Slavery. Mystical Form of Social Slavery.

WhERE the transition has taken place directly from the hunter to the agricultural state, the influence of mystical ideas seems to have been employed to supply the place of chattel slavery. The shepherd state does not appear to have been known in aboriginal America. The Mexicans had no domestic animals, the Peruvians only the lama. These nations appear to have passed directly from the hunter to the agricultural state - a change, however, not effected, except by first totally subduing the minds of the mass by the force of mystical terrors; thus rendering them passive instruments in the hands of their governors, in fact the slaves, if not of individual owners, at least of the governing power. The 
history of the Jesuits in Paraguay, and of those other American missions already referred to, will help us to conjecture by what means the earlier aboriginal empires of Mexico and Peru were established.

The system of social slavery, thus in its earlier form based on the influence of mystical ideas, and in that shape of very great antiquity, we shall presently find reappearing at a much more advanced period of human progress, under very different circumstances, being established and sustained by very different means, and destitute of many of the alleviations with which the earlier form of it is attended.

\section{Section Eighth.}

\section{The Chieftain becomes a King.}

IN making necessary the establishment of property in land, agriculture gives occasion for new exercises of civil authority; at the same time, by increasing the means of subsistence, it increases the numbers of the community; and the power of the chieftain thus increasing in extent and intensity, he becomes that which is described by the word KING.

Thus, at length, a state of things is reached in which the original monarchy, having started an obscure and indistinct embryo, takes on its complete development. Thus it is that kingdoms take their origin, built sometimes on a forensic, sometimes on a mystical foundation, more frequently, perhaps, on both united. In proportion, however, as the kingly power rests upon a mystical foundation, its intensity 
is greater; and where mysticism is its principal element, it assumes, even in the smallest communities, a character of complete despotism.

\section{Section Ninth.}

\section{Extension of the Original Kingdom by Conquest.}

Afrer wealth begins to be accumulated in the shape of flocks, herds, and slaves, war assumes a new character. Generally speaking, savages engage in war merely to gratify their sympathies and their malevolence, and for the sake of certain pleasures of activity and superiority. But after wealth begins to be accumulated, however the gratification afforded by war to the sentiments of self-comparison, of malevolence, and of admiration may prevent its main object and intent from being discerned, it becomes, on the part of the aggressive party, very little different in its character from highway robbery, except in the magnitude of its scale of plunder. Partly owing to the vast expenses involved in the prosecution of war. according to modern methods; partly owing to the advances made in the science of wealth, or what is called political economy; partly by reason of the limitation introduced among civilized nations, and partially adhered to, that private property is to be respected, - it has come, within a very recent period, to be perceived that plunder and conquest are neither the surest nor the shortest road to opulence, nor even to power, of which opulence has become so important an element. Hence, in part at least, 
the marked indisposition of the more civilized and powerful nations, during the last third of a century, to make war on each other; the appeal to arms being mostly reserved for the case of semi-barbarous and comparatively helpless neighbors - Caucasians, Algerines, Arabs, Caffres, Burmese, Chinese, Seiks, Mexicans; while even as to them, the war policy comes, day by day, to be regarded as more and more questionable.

In ruder times, and especially among shepherd tribes, the seizure of the property and persons of their neighbors presented itself as the shortest, surest, and least troublesome means of accumulating wealth a view which the result of a successful war would tend greatly to confirm; the flocks of the neighboring tribes being thus added to those of the victors, their pastures extended, and their slaves multiplied.

As long as conquest, in such cases, is confined to neighboring tribes of similar manners, language, and religion, the conquered are absorbed into the body of the conquerors, and the community still preserves its original homogeneous character. Even though the individuals of the conquered tribes be reduced to slavery, that slavery, owing to the actual equality upon most points, so long as the shepherd state continues, of the masters and the slaves, is comparatively mild, and such slaves easily regain the position of freemen. It generally happens, however, that the beaten tribes, by submitting in time, are able, by the sacrifice of a part of their wealth, to secure their adoption into the victor tribe upon terms of equality, or something approaching to it.

By this continual aggregation of numbers, the con- 
quering tribe grows more powerful and more able to extend its conquests, and often, in a very short time, a great number of tribes originally independent become united under one regal head - of which we have striking instances in the sudden rise and rapid progress of many Turkish, Tartar, and Mongol em. pires.

The king of the conquering tribe or confederacy himself comes in for a great share of the spoils thus acquired; as the leader in these enterprises, he is constantly giving new proofs of sagacity, courage, and activity; and hence the admiration with which he is regarded constantly increases, and his power along with it.

\section{Section Tenth.}

Contact of Shepherd Kingdoms with Agricultural States.

Presently this growing kingdom, which we may suppose to consist, as yet, merely of migratory shepherds, begins to come into contact with agricultural communities - either such as are forensically governed, carrying on cultivation by means of slaves, or theocracies in which, by the force of mystical ideas, the mass of the people have been subdued into perfect submission, and substantially converted into the slaves of the theocratic order; or possibly the social condition of these states may embrace both of these elements.

These agricultural communities, by reason of their greater amount of accumulated wealth, including 
many articles, such as wine, oil, corn, and other luxuries hardly known before to the barbarian shepherds, hold out powerful temptations to the invaders, whom, at the same time, they are often ill able to resist.

In agricultural states forensically governed, the freemen who keep their slaves in subjection mainly by superior force will, it is likely, be warriors, whom superior weapons, and often their better acquaintance with the science of war, will enable to make a stout resistance to their barbarous invaders. But there will be two great disadvantages under which they will labor. They have an internal enemy in the servile population; and, from the very fact that the cultivators are slaves, the military force of the state will bear but a small proportion to the whole number. Yet it generally happens, unless the increase of wealth has rendered those in authority luxurious and unwarlike, that forensic agricultural states, though they may yield to the first onset of the invaders, finally succeed in repulsing the shepherd hordes by which they may be attacked; or, if they yield at last, they yield only to a long succession of inroads.

The fate of theocratic agricultural states is generally different. In theocracies, the supremacy of the rulers is chiefly sustained, not by the possession of arms and skill in the use of them, but by the influence of mystical ideas. In theocratic states, at least those of long standing, military exercises are generally disused, and military science little cultivated; so that these states often fall an easy prey to barbarian invaders, against whom the spiritual terrors of the theocracy are, at first, of no avail.

But even in these cases, the theocracy generally 
contrives, in the end, to regain its ascendency, and to convert its late conquerors into its instruments, or, at most, but its partners in power. The superstitious spirit of ignorant barbarians is very easily operated upon by a priesthood comparatively enlightened and learned, skilled in all the arts of mystical influence, and doubly stimulated, not only by the hope of regaining the position they have temporarily lost, but also by the desire of making new converts. So it happened to the barbarians who subdued the Roman empire, but who were themselves subdued by the Roman priesthood, as well as to the Turkish and Tartar hordes which successively seized upon the ruins of the caliphate.

Upon the mass of the population - the subject, servile class, the cultivators of the soil - these revolutions, whether the original conquest or the reëstablishment of the theocracy, have comparatively little effect. Subject and servile they still remain through the whole process, experiencing only a change of masters. And yet, though it may not degrade their condition, (that condition being already as low as it can be short of chattel slavery,) still the conquest of a theocratic state by a shepherd tribe is often very disagreeable to the mass of the people as well as to the priests. The rule of the new conquerors inflicts pains of inferiority, which, instead of being neutralized by pleasures of admiration, are aggravated by pains of malevolence and of fear. The soothing influence is no longer felt of those mystical ideas under which their theocratic masters had been submitted to as men submit without struggle, and almost without complaint, to the operation of known and familiar 
laws of nature. Moreover, the new masters, being less cultivated, and, by consequence, less humane, than the old ones, and being filled with contempt for the unwarlike spirit and servile condition of their new subjects, generally exercise their power with a harshness and violence unknown during the times of the theocracy.

Besides those invasions of shepherd tribes from the steppes of Tartary, by which, within the period of authentic history, almost the whole of the old continent, except that portion of Africa south of the Desert of Sahara, has been overrun, there are sufficient indications that in much earlier times, prior to the commencement of authentic history, similar invasions and conquests had already taken place. It seems to be clearly established by similarities of language, - both as relates to individual words and to grammatical construction, - that the Celts of Gaul, Spain, and Britain, a portion of the ancient inhabitants of Central and Southern Italy, the Greeks, the Germans, the Goths, the Sclavonic tribes, the Persians and the Hindoos, were offshoots from the same parent stock, whose original seat can only be looked for on the table land of Central Asia. Indeed, the possession, by all these nations, of horses, flocks, and herds, - animals of which the primitive wild types no longer exist, - and more especially the use of war chariots, tends strongly to show that their ancestors must have come from a country of grassy plains, in which only such animals would be looked for as indigenous, and where alone such instruments as war chariots were likely to be invented, to the use of which the rough mountains of Greece, and the 
woods of Gaul and Britain, were but very ils adapted.

The aboriginal inhabitants of the countries seized upon by these shepherd invaders suffered, no doubt, the same fate which the Saxons afterwards inflicted on the Britons; a part were exterminated, a part were adopted into the conquering tribes, and a part remained, or were made, slaves. Not improbably the Druidical religion may have been the religion of the ancient inhabitants of Gaul and Britain, imposed upon the conquering Celts, by the arts of the priests, in the same way that the Goths and Franks were, in subsequent ages, converted to Christianity. To what degree of civilization some of these nations and perhaps the ancient Etrurians were one of them - may have attained, previous to their conquest by the shepherd tribes, the analogy of Babylonia, Egypt, China, Mexico, and Peru may enable us to conjecture.

When agricultural and civilized states fall into the possession of shepherd conquerors, it frequently happens, amid the quarrels of contending dynasties, and the disorder and insecurity which these barbarian conquerors bring with them, that wealth, civilization, and population gradually decline; that agriculture, except to a limited extent, is abandoned; and that, as the fields - no longer cultivated - reassume their original wildness and woodiness, pasturage becomes the chief resource of the people, and the woods and mountains are again filled with wild game.

This is what happened to the western provinces of the Roman empire, in consequence of repeated invasions and conquests by shepherd tribes from 
Germany and Sarmatia; and at a later period to its eastern provinces, in consequence of repeated Turkish invasions and conquests - a consideration which will add to the probability that nations comparatively civilized might, before the period of the Celtic invasion, have existed in Western Europe.

Though empires formed by the conquests of shep-. ard tribes, like that, for instance, of Attila, have often reached a vast extent in a very short period, these empires, for the most part, except where they have become ingrafted on some preëxisting theocracy, have been very short-lived. In the times of the sons or the grandsons of the original founder, they have generally split into fragments; which again have been united by some new conqueror, and again dissevered; and so on in rapid succession. 
OLIGARCHIES, ARISTOCRACIES, ETC.

\section{CHAPTER III.}

OLIGARCHIES, ARISTOCRACIES, TYRANNIES, SECOND. ARY MONARCHY.

\section{Section First.}

Circumstances under which a Higher Political Development becomes possible.

Tre preceding chapter embraces the complete cycle, from the earliest to the present times, of the political history of the shepherd tribes mhabiting the broad plains of Central Asia, and of those agricultural nations, such as, in very early ages, were planted on the banks of the Euphrates, the 'Tigris, the Nile, the Indus, the Ganges, and the great rivers of China, exposed, with no natural barriers of defence, to the aggressive irruptions of these pastoral communities.

But when, in the course of its wanderings, one of these pastoral tribes becomes possessed of a mountainous and defensible country, where, by the advantage of local position, a small tribe is able to maintain itself against great numbers, and where the fertility of the soil, the mildness of the climate, and a maritime position favorable to commerce, afford means for the development of civilization; in these few and favored cases, - of which the coasts and islands of the Mediterranean Sea have afforded the principal historical instances, - a new series of political changes 
presents itself, which will best be illustrated by direct refercnce to the history of the Grecian and Roman commonwealths.

\section{Section Second.}

\section{Illustrations from Grecian History. The Promitve Grecian Kingdoms.}

IT would seem, from the genealogical and mythological traditions, which furnish all the verbal memorials that we have of the state of things in Greece previous to the establishment of the Grecian republics or commonwealtlis, as well as from many customs and observances which prevailed subsequently to that period, that the Greeks originally consisted of a number of pastoral, migratory confederacies or clans, of which the Dorians and Ionians were, or finally became, the most famous; protected from conquest during the ante-historic ages, as they were during the illustrious portion of their historical period, by the mountains and fastnesses among which they dwelt. Certain foreign adventurers - fugitive priests, pirates, merchants, or expelled princes, or persons sometimes, perhaps, combining all these characters - arrived among these tribes, from Phœnicia, Egypt, and Asia Minor, countries, compared with Greece as it then was, possessing a high degree of civilization. These adventurers brought with them the use of letters, the knowledge of navigation, agriculture, and the arts; and partly by their superior knowledge and sagacity, and partly by the influence of mystical ideas, - for 
the Greeks, like all uncultivated people, were very superstitious, of which these foreigners seem generally to have taken advantage to represent themselves as the children or favorites of some god, - they raised themselves to the chieftaincy of the several tribes. In imitation of the countries whence they came, they built walled towns for defence against predatory incursions, they raised temples, established religious ceremonies and festivals, and introduced agriculture and some commencement of civilization. Such is the state of Greece, as presented to us in the poems of Homer, - the earliest written memorials of that country, if not indeed of any country, which we possess, - and in the traditions on which the Greek tragedies were founded; out of which the writers of the Alexandrine school attempted to construct a regular history and chronology, commencing with the first Olympiad, (B. C. 776,) and even ruming back for certain ages anterior to that period.

\section{Section Third.}

Greek Oligarchies, Aristocracies, Democracies, Tyrannies.

The line of direct descent, in the families of the Greek chieftains of the heroic age, having come to an end, and there being no single person in the community upon whom the joint influence of mystical ideas, of the notion of property in power, and of traditional respect, united to confer the successorship, the government fell into the hands of a number of 
families, greater or less, which excelled in wealth, which claimed collateral descent from the former kings, and which, by engrossing the priesthood, and the administration of religious ceremonies, were able to avail themselves, more or less, of the influence of mystical ideas. This mystical influence, in the earlier periods of Grecian history, was very considerable; but it never, as with the Egyptians, Etruscans, and Druidical Gauls, superseded or obtained the control of the other elements of power; so that Greece, notwithstanding the excessive superstition of its earlier inhabitants, of which so many strong instances appear in Herodotus, was fortunately preserved from a theocratic government.

'This new form of administration, known afterwards, when the Greeks came to consider the subject philosophically, as an Oligarchy, or government of a few, continued to prevail, especially among the Dorian clans, for several generations. But, for the most part, the few ruling families found themselves constrained to admit, from time to time, other families, which had acquired wealth and influence, to share their authority; till the government gradually became what the Greeks called, and we call after them, an Aristocracy; literally, a government of the best - either best in point of birth, or best in point of wealth, the phrase good being often, in the language of politics, as in that of commerce, synonymous with wealthy. Nor indeed is this confusion of terms entirely destitute of foundation in fact, since the possession of a competency, by relieving men from the constant and overwhelming pressure of several imperious wants, puts them into a position in which virtue becomes at least possible. 
When this aristocracy, or government of the wellborn and wealthy, was so extended as to admit all the free citizens to share in the administration, it was then distinguished as a Democracy. But this Grecian democracy, it is to be noted, was still a select class limited to those who possessed the right of citizenship, and excluding slaves, freedmen who had been slaves, strangers, and mere denizens; who together often made up the bulk of the population; such, indeed, as would be regarded, in our day, as still a pretty select aristocracy.

It would, however, occasionally happen that some individual citizen of great wealth, warlike skill and science, sagacity, eloquence, or reputation for patriotism, was able to obtain such an influence over the community as to concentrate the whole administration of the government in his own hands; and, in later times, the same object was frequently accomplished by the employment of mercenary troops, by whom the citizens were kept in obedience and awe. This form of government-a restoration of mon- . archy equally disagreeable to the partisans of oligarchical, aristocratic, and democratic administration - was called a Trranny - a name to which the ideas of usurpation and violence were intimately attached. It was in the hatred and dread of tyranny that the practice of ostracism and other similar contrivances originated, by which the Greek commonwealths were enabled to rid themselves of the presence of citizens who, by reason either of their talents, their wealth, or even their virtues, appeared so influential as to threaten the concentration of all power in themselves. 
Section Fourth.

Greek Revolutions. Secondary Monarchy.

ThE Greek oligarchical forms of government were much the most permanent, which is to be ascribed, in part, to the fact that they chiefly existed in the purely . agricultural states, in which the movement of ideas is always comparatively slow. Such was the government of Sparta. Athens, Syracuse, and many other states, made opulent by commerce, were greatly distracted, and were exposed to constant revolutions by struggles for power between the poorer citizens, called the democracy, and the richer citizens, called the aristocracy; these aristocracies corresponding, in fact, to the Spartan oligarchy, and generally keeping up a close correspondence and alliance with it. The democratical and aristocratical factions, as they successively obtained power, treated their opponents with great severity. Death, confiscation, and banishment were frequently inflicted by either party, as it alter nately prevailed; and the bitterness of the feud was thus constantly aggravated. Sometimes the government assumed the form of a tyranny - which frequently happened after the advance of refinement and luxury had made the hardships of war distasteful to the rich, and had led to the introduction of mercenary soldiers, always ready to fight for any body who would pay them.

At length appeared upon the stage Philip of Macedon, a man of great sagacity, policy, skill in arms, courage, activity, perseverance, and self-control, de- 
scended from an ancient Greek family, which had raised itself to the kingship of the Macedonians exactly as, in earlier ages, foreign adventurers had established similar kingdoms in Greece itself. Availing himself of the physical force thus aggregated in his hands, and taking advantage of the decay of the military spirit, and of personal skill and hardihood, among those in the Greek commonwealths who exercised the political power, and especially of their domestic quarrels, he accomplished that in which, as to the European Greeks, the kings of Persia had failed some two centuries before; being enabled to reduce the whole body of them, at least those of the primitive and central Greece, to a dependence on himself. His son Alexander, still more distinguished for his personal qualities, by the help of Greek mercenaries, who had carried the science of war to a perfection elsewhere unknown, established a vast empire, which fell, however, into fragments immediately after his death.

Several of these fragments were seized upon and held by the generals of Alexander's army; others were taken possession of or regained by the native princes. The main support of the Greek kingdoms established on the ruins of Alexander's empire was a standing army of mercenary troops trained after the Greek model, and fed and paid out of the revenues of the state; a comparatively small body armed, disciplined, and acting in concert being an overmatch for almost any number unarmed, uninstructed, untrained, and uncombined. This form of government, for the sake of distinction, we denominate Secondary Monarchy. As in the case of the primitive monarchy, traditionary 
respect, the idea of property in power, and, to a certain extent, mystical influences also, are presently added to the mere force out of which it at first grew; and, in the course of time, it may take on a character hardly distinguishable from that of the original kingdom.

Section Fifth.

Illustrations from Roman History.

The history of Rome furnishes us with a series of changes similar to those which make up the history of the Greek commonwealths - from monarchy to an oligarchy of patrician families; from oligarchy to an aristocracy, into which the plebeians were at first slowly and partially admitted, but which gradually expanded into what the Greeks called a democracy; from that back again to an oligarchy of three or four influential individuals; from this new oligarchy to tyranny; which, dropping by degrees republican forms, changed gradually into secondary monarchy.

We may discover, howeyer, in the Roman commonwealth a political phenomenon scarcely perceptible, if at all, in the Grecian states, but elsewhere much more fully developed, and of which we shall have presently more to say - that of the division and distribution of power. In the case of the Roman commonwealth, this distribution took place between a narrow aristocracy represented by the senate and the comitia centuriata, (in which latter assembly the few rich decided every thing,) and a more extended aristocracy, of that kind called by the Greeks a 
democracy, acting through the agency of the comitia tributa. Instead of struggling for power, and alternately possessing it, these differently-constituted assemblies exercised a concurrent, and, but for the tribunitian office, almost an independent authority. The tribunes of the people, elected by the comitia tributa, possessed, indeed, the singular right of putting a veto upon the decrees of the senate, and the acts of the magistrates elected by the comitia centuriata. In fact, however, notwithstanding this check, the senatorial power was, pending the whole continuance of the commonwealth, except during two or three temporary outbreaks, always in the ascendant. The tribunes were always overawed, bribed, or assassinated by the senatorial party. The attempts of the Gracchi and others to share among the mass of the citizens some portion of that plunder of conquest which the senators divided so liberally among themselves were promptly and violently suppressed. The temporary triumph of the popular party under Marius, in spite of the senatorial blood shed to perpetuate it, was immediately succeeded by the proscription and the dictatorship of Sylla, who restored the power again to senatorial hands. Ultimately, however, the senate fell into subjection to a triumvirate of its own members, placed, one of them by his immense wealth, and the others by prolonged and almost independent military commands, quite beyond senatorial control. That triumvirate, dissolved by the death of Crassus, was succeeded by a struggle for power between Pompey, who claimed to act for the senate, and Cæsar, who intrigued with, and used for his own purposes, the tribunes of the people-a struggle ending in the 
dictatorship of Cæsar, who, instead of strengthening the democracy at the expense of the senate, as Marius had done, sacrificed both to make himself perpetual dictator and tyrant. The tyrant fell by the daggers of Brutus and Cassius; but they were unable to reestablish the senatorial authority; and the government soon passed into the hands of a new triumvirate, ending in the sole reign of Octavius Cæsar, who quietly transmitted the supreme control to a successor of his own appointment.

The authority of the Roman emperors, in the days of the first Cæsars, was chiefly sustained by the arms of the legions, and of the prætorian guards; and, down to the final termination of the empire, whenever an emperor had fixed upon his successor, the first step was to get him acknowledged as such by the soldiers. But, in process of time, there sprung up a traditionary respect for the imperial authority, by which it was greatly strengthened in the hands of whomsoever possessed it.

As in the early days of Greece, so in the earlier times of Rome, mysticism had been a great bulwark of authority. 'The office of priest and augur had been combined with that of magistrate, and the senate had made. great use of this influence to awe or baffle the people, and to sustain its own authority. With the advance of science, and the consequent decrease of superstition among the more enlightened portions of the community, this source of power had very much diminished; which circumstance will enable us to understand the lamentations of certain Greek and Roman authors over the decay of religion. The earlier Roman emperors, however, took care to 
combine in their persons, along with all the chief civil dignities of the republic, that, also, of supreme pontiff With the subsequent decline of science, the influence of mystical ideas revived; and the spread and growth of the Christian church introduced a new power into politics. But presently this new power, found by trial too potent to be resisted, was availed of for the support of the empire by the adoption, under Constantine and his successors, of the Christian religion as that of the state; from which time forward, the influence of the clergy has continued a very powerful element in European politics. 


\section{CHAPTER IV.}

REVOLUTIONS OF MYSTICAL GOVERNMENTS.

HAVING thus considered the cycle of changes through which the original forensic monarchy may pass, it remains to trace the revolutions of the mystical monarchy, the other original type of that form of government.

We have already explained how the original mystical monarchy springs up among savage tribes. But the same form of government often takes its origin in a community possessing an organized system of some of the kinds already described. Sometimes this is the mere revolt of a conquered priesthood, against some foreign yoke imposed upon them; the reëstablishment of some old theocracy; the high priests, upon the overturn of the foreign power, raising themselves to the position of kings. Such was the Jewish monarchy founded by Judas Maccabeus. In other cases, the new monarchy first presents itself as a religious sect, the head of which claims a special divine authority - sometimes as the founder of a new religion, but oftener as the reviver and reformer of an old one. Sometimes such a new sect spreads rapidly, raising its founder, or his immediate successors, to so great an influence and power, that he is able to overturn the existing government, and to establish a theocracy in its place, of which he becomes the head. Such was the case with Mohammedanism. In other instances, the new sect increases only by slow degrees, remains for a long time an imperium in imperio, and only after 
a long struggle with the existing government, and enduring many persecutions from it, makes good its supremacy, and either supersedes that old government or else rules through it-revolutions of which the history of the Christian church furnishes abundant examples.

All theocracies are monarchical in their inception, and are always so in theory; but upon the death of the founder, or any interruption in the line of his successors, they may, like the forensic monarchy, take on an oligarchical or aristocratical form, the administration being shared among a number, greater or less, of the priests or ministers, who rule in the name of the deified founder; or, by admitting the great mass of believers to a share of authority, they may even assume a democratical shape. Such seems to have been the case in the early days of the Christian religion; and it is perhaps in a considerable degree to this democratical element that we are to ascribe the progress of that church during the first two centuries that interesting, but very obscure, period of its history.

It generally happens, however, that, by a process very similar to that to be presently described in the case of certain forensic governments, a select body, tending constantly to grow still more and more select, - the professors, the elders, the priests, the bishops, - sooner or later usurp the whole control, and subject the mass of the laity to a servile submission. A theocratic order of nobility, often hereditary, thus once established, by processes analogous to those already pointed out in the case of lay aristocracies, it is occasionally superseded, now by a theocratic oligarchy, and now by a theocratic tyranny, liable to. 
be again replaced by theocratic aristocracy, or theocratic democracy. Such was the revolution by which the power and influence of the Catholic clergy, after rising to a great height, was overturned in all the nations of Northern Europe, and superseded by a new Protestant priesthood. It is true that in some of the Protestant states - as, for instance, in England, and in many of the countries which adopted Lutheranism - this change was more apparent than real; the Protestant clergy in those countries being little else than a continuation of the Popish clergy, with some trifling modifications in ceremonies and articles of belief. In Scotland and the Calvinistic states, the change was somewhat more complete; but it was only among the Anabaptists and the English Independents that the revolution received its extreme democratic development. Claiming an entire spiritual equality for all the members of the Christian brotherhood, those sects recognized, in fact, no priests. But, as in the case of other similar democratic claims, it has not been found very easy to substantiate this one in practice; since in no single thing are men more unequal than in their capacity to be acted upon by mystical ideas and convictions. A leadership and control over their admiring and awe-struck brethren falls naturally into the hands of the specially gifted; and the attempt to carry out the theory of absolute human equality proves still more a failure, if possible, in religious than in civil organizations. 


\section{CHAPTER V.}

DISTRIBUTION AND DIVISION OF AUTHORITY. MIXED FORMS OF GOVERNMENT.

\section{Section First.}

State of Things which attended and followed the Downfall of the Roman Empire. Serfdom substituted for Chattel Slavery.

IN the slight sketch given above of the Roman history, reference was made to a curious political phenomenon, not elsewhere so clearly developed in ancient historical times - that of a distribution or division of the sovereignty between two distinct orders in the state. In the period subsequent to the downfall of the Roman empire, this phenomenon became still more distinctly and remarkably developed.

The governments existing among the Gothic and German hordes, when they first commenced their inroads upon the Roman empire, were primitive monarchies of the kind already described, essentially the same with the Homeric monarchy of the Greeks, and the chieftaincies of the Scotch and Irish clans, the extent of the power of the rulers being greatly dependent on their own individual energy.

- These moving bands of shepherd warriors, after being repeatedly repulsed, and as often bought off, finally established themselves within the borders of the empire, and seizing upon the lands, slaves, and 
other property of the Roman nobles and clergy, appropriated them, in whole or in part, to their own use. But soon enervated by wealth and luxury, they were presently swept away by bands of more sturdy barbarians fresh from the north and east, who, in their turn, made a similar appropriation of the wealth they found; and in their turn were subdued and swept away by new invaders.

For upwards of six centuries, Goths, Vandals, Allemanni, Suevi, Lombards, Franks, Saxons, Avars, Normans, and various Slavic and Turkish tribes contended with each other, and with the descendants of the Roman provincial population, for the possession of Europe, or of parts of it. At an early day of this dark period, the Western empire was overrun - and for the moment almost subdued - by a vast array of Huns, from the confines of China. At a later day, the same territories had almost fallen into the hands of the Saracens, who, following the south shore of the Mediterranean, and having subdued the Roman African provinces, obtained possession of Spain and Sicily, whence they penetrated into France and Italy, from which they were with difficulty repulsed.

In consequence of these perpetual struggles for the ever-diminishing remnants of Roman wealth, and the disorders and insecurities attendant upon them, the civilization and the population of Europe retrograded from century to century. The attempt of Charlemagne to build up again an empire of the West failed with his life. His dominion was soon split into numberless fragments, still further wasted by Norman, Slavonic, Saracen, and Madjar invasions, while the Holy Roman empire, by him reëstablished, became, like its predecessnr; hozt an empty name. 
Towards the middle of the tenth century Europe was reduced to such a state of poverty and desolation that there seemed hardly any thing left to plunder; yet this very impoverishment appears to have been an essential step towards introducing a great social change - one of the main corner stones of the new edifice of civilization about to be raised on the ruins of the old.

The race of slaves, the sole cultivators of the broad and once wealthy domains of the Roman provinces, seem never to have offered the slightest resistance to any invader. It was, indeed, the lack of free men who could be turned into soldiers - for which purpose the enervated town inhabitants were unfit - that made it so difficult to defend the empire, which was only maintained, from the first, by the ingenious device of employing the barbarians to fight each other. With the decline of wealth, not only did the importation of new slaves come, for the most part, to an end, but the old ones, or their descendants, became attached to the soil - no longer chattel slaves, but serfs, bound to the land, and constituting, along with it, one article of property. These serfs, from the moment of becoming such, began to acquire additional privileges. Some presently became tenants, at a fixed rent, in labor, produce, or money, to which the demands of the lord were limited. Others, escaping into the towns, became citizens there.

Many circumstances, not necessary to mention here, have contributed to the gradual, though as yet very imperfect, emancipation of the laboring classes of Europe - the first step towards the erection of the system of modern civilization; a civilization, 
however, at present incomplete, yet far superior to that of the ancients; which, in the universal enslavement of the laboring classes, carried within its own bosom the seeds of inevitable decay. It was in this new race of freemen - having now an interest in the soil, or town hearthstones of their own to defend that the means of effectual and permanent resistance to new invasions of wandering tribes of warlike shepherds first presented itself.

\section{Section Second.}

\section{Origin and Character of the Feudal System.}

THrs new array of the resident population for selfdefence against that tide of military spoliation which for so many ages had so resistlessly and fatally swept over Europe, gradually took on the form of what finally became so famous as the Feudal System - a system in which we find comprehended many fragments of the organization introduced by Constantine and his successors for the defence of the later Roman empire, many barbaric usages which the invading tribes had brought with them from the plains of Sarmatia and the woods of Germany, and many customs produced by the necessities of the moment or by local convenience. The leading idea, however, was, that the possession and usufruct of the land should be in the hands of fighting men, bound to maintain it, and the lords under whom they held it, against all aggressors.

As the Roman empire had been formed by the 
subjection of a vast many independent communities, so, in the process by which the feudal system was arrived at, that empire had again resolved itself into elements, similar, in many respects, to those out of which it had been originally aggregated. For out of its ruins there sprung up not only a great number of feudal dukedoms or counties, nearly or quite independent, - the Roman titles of dukes or counts, given originally to the imperial officers of certain territorial divisions, superseding for the most part the native appellations of the barbaric chiefs, - but the wasted remnants of ancient cities now recovered again that independence which for so many ages they had lost; and among the other various changes that were going on, and under the shelter of the walls with which those towns now began again to surround themselves, republican governments once more reappeared.

Yet amid all this resolution of the Roman empire into detached and independent fragments, there still survived certain ideas of unity, constituting, indeed, an essential part of the feudal system; ideas which tended to the reconsolidation of authority; but upon a principle essentially different from that mere aggregation of conquests to which the Roman empire had owed its origin.

\section{Section Third.}

Monarchy as an Element of the Feudal System.

As the barbarian, conquering Romans were themselves subdued by the superior knowledge and refinement of the conquered nations, particularly of the 
Greeks, and the communities under Greek influence, in like manner were the northern and eastern barbarians who conquered the Roman empire subjugated by the language, manners, and ideas of the people they had overrun. In imitation of the Roman emperors, the barbarian princes promulgated codes, borrowed as to many particulars from Roman models. Copying from those same models, they assumed new airs, dignities, and titles, claiming for themselves a certain portion of that traditionary respect and supereminent honor which not only the citizens of Rome, (and all the free subjects of the empire had come in time to be acknowledged as Roman citizens,) but their own predecessors also, had long paid to the Roman emperors. In the progress of darkness, barbarism, and disunion, these ideas became, indeed, almost extinct; but presently the revival of the study of the civil law reproduced them with fresh force.

It was this notion of central, imperial authority which still gave a certain unity to France, Germany, and Italy, even after they were split into an infinity of dukedoms, counties, and municipalities, many of them substantially independent; and it is this same idea which forms the key to the struggles carried on for so many centuries between the kings on the one hand and the feudal nobility on the other - the municipalities and the clergy appearing, at different times, on either side; a struggle which terminated in Germany in the almost complete triumph of the feudataries, but in England and France in the reëstablishment of the authority of the monarch. 


\section{Section Fourth.}

The Power of the Clergy as an Element of the Feudal System.

STILL another idea, which survived the downfall of the Roman empire, and which operated to retain not single countries only, but the whole of Christendom, - notwithstanding the thousand fragments into which it was divided, - in a certain bond of connection, was, the idea of the unity of the Christian church.

The obscure rise of the Christian sect during the first century and a half of our era, the wealth, and presently the political power, which, after a certain period of slow and unnoted progress, the Christian priesthood rapidly acquired, during the second, third, and fourth centuries, making even the imperial power but a stepping-stone for their advancement, is one of the many astonishing revolutions to be traced to the influence of mystical ideas. The successive hordes of barbarians which overwhelmed Europe were, at first, all heathens, the Saracens excepted, who were under the influence of a mystical system of their own, which rivalled, and at one time threatened to extinguish, the system of the Christian church. But, like all ignorant men, these barbarians were extremely susceptible to the influence of mystical ideas; and though they began by plundering and murdering the monks and the bishops, they always ended by being converted and baptized, and by giving back to their ghostly fathers a great deal more than they had taken away. 
Encouraged by this docility on the parn of their new converts, the clergy were not long content with mere gifts of lands and goods. They sometimes obtained by grant and concession, and sometimes they usurped, rights of jurisdiction also ; so that presently a whole host of mitred abbots and bishops appeared upon the scene of the feudal times, with the crosier in the one hand and the sword in the other, struggling with the kings and the nobles for independent political power.

Very early in that age, - at a period when nobody hardly but monks and priests could read, and when almost the entire intelligence of the community was to be found in the clerical order, - the clergy, under the able leadership of Gregory VII., came very near establishing a grand theocratic monarchy throughout Christendom, (from that time to this the beau ideal of the ultra Papists,) of which the pope was to be the head, the bishops and abbots the administrators, and the kings and nobles the humble and submissive instruments - instruments which might presently have been dispensed with altogether.

Though this magnificent scheme for a theocratic monarchy over all Christendom, and ultimately over the whole world, did not succeed, yet several bishops of the German empire, as well as the pope, were able to establish their supreme and independent dominion over extensive and populous districts, of which they became the theocratic princes. The English and French clergy, on the other hand, like the nobility of the same countries, found themselves obliged to give over the idea of independent authority, and to be content with an influential share in the general administration of the government. 


\section{Section Fifth.}

The Feudal Age Municipalities. Their Freedom from Chattel Slavery. Origin and Fundamental Ideas of Modern Democracy.

As an element in the feudal system, in addition to the power of the nobles, the kings, and the clergy, - one at first obscure and humble, but gradually increasing in importance, - must be mentioned the municipalities already referred to, many, indeed most of the older ones, erected on the very sites of ancient cities, older than the Roman conquest; and in and by which, with the commencement of the feudal times, the idea of republicanism was, after a long interval, revived.

In the position finally attained by these additional claimants of authority, we may observe, as with respect to the clergy, a different result in Italy and Germany from that which took place in England and France.

In Italy, at an early period of the feudal times, and subsequently in Germany, a large number of these municipalities became, in fact, if not in name, entirely independent; and several of them reached a pitch of opulence and power such as enabled them to contend and to take rank with popes, kings, and emperors. By a departure from the principles upon which they had been originally established, and to which they had owed, in a great measure, their rise and importance, all these feudal age republics, by a course of revolutions which vividly recalls the history of the ancient 
Greeks, fell, at length, a prey to domestic tyrannies, monarchic or oligarchic, and, with a few exceptions, were ultimately swallowed up by their stronger neighbors, exactly as the Greek republics had been at an earlier period. In France and England, and, we might add, in Spain, the municipalities never obtained an independent authority, but were obliged to be content, like the clergy of those countries, with being admitted to a share, and at first a very moderate one, in the control of the national government.

As the civilization of the ancient Greeks, as well as that still more ancient Phœnician civilization to which the early Greeks appear to have been so much indebted, and which reached its ultimate development in the republic of Carthage, took its rise in the municipal spirit, and unfolded itself, and attained its highest perfection, by means of republican organizations, so in the municipalities of the middle ages the origin is to be sought and found of our modern civilization. If, in our time, these municipalities may seem, on a cursory view, to have become less politically prominent than formerly, it is none the less a fact that, so far from growing effete, the municipal spirit - that is, the ideas and feelings to which the municipalities of the middle ages owed their rise and growth - has been making, for centuries, a constant progress; modern civilization having advanced and extended itself simultaneously with the municipal spirit, and just in proportion to it. Certain clear indications also appear that the municipal element in the mixed governments of Europe, having undergone an extension wide enough to embrace the whole community, is destined, and that at no distant day, to 
swallow up all the others, and to vindicate for itself that lasting supremacy which priests, nobles, and monarchs have struggled for in vain.*

In one striking and most important particular, the municipalities of the middle ages appear to have differed from those ancient municipalities upon the sites of which many of them were erected - a particular which seems to have produced all the difference, so very great, and, it may be said, radical, between the civilization of ancient and of modern times.

In the municipalities of the middle ages, for the first time, in civilized communities, within the period of authentic history, chattel slavery was unknown. Even serfdom was not recognized; and both slaves

* Guizot, in his History of the Civilization of Modern Europe, was the first to call particular attention to the fourfold distribution of power in the middle ages, such as it is above described. Finding this distribution of power between monarchs, nobles, clergy, and municipalities coincident with the rise and progress of modern civilization, he somewhat hastily concluded that the continued existence and balance of all these classes was and is essential to that progress. Had he been a little less of a scholar, and somewhat more of a philosopher, or had he even possessed the advantage of our American point of view, a more profound and comprehensive study of history, the history of the present day as well as that of the middle ages, might have convinced him that, in the progress of modern European civilization, the monarchic, aristocratic, and clerical elements have only been so far useful as they have served to counteract and to destroy each other; the whole of the actual progress being due to the municipal element alone. Had M. Guizot more clearly perceived this truth, his career as prime minister might have been more judicious and more fortunate. Foresight of the future is an excellent thing. Knowledge of the past is an excellent thing; and for his contributions to it M. Guizot is well entitled to our respectful gratitude. But for the administration of affairs, there is necessary a perception of the present so strong and real as to throw both past and future quite into perspective - a sufficient reason why both scholars and philosophers may occasionally fail as practical statesmen. 
and serfs, flying from the tyranny of brutal masters, found convenient refuge and protection within the walls of the towns, of which they helped to augment the population, and to increase the strength and wealth. Laborious industry, as well that of the mechanic arts as of agriculture in the verge of territory attached to the towns, was now, for the first time, carried on by free citizens. Freedom and industry thus reconciled, the arts, under their impulse, soon made a progress which first equalled and finally surpassed any thing known among the ancients. Combining trade with manufactures, to which those towns favorably situated for it, like Venice, Naples, Genoa, and Pisa, added navigation, these municipalities rapidly accumulated wealth, which, as we have seen, is a most important element of political power; while the compactness, as well as the superior intelligence, of their population, by facilitating combined action, gave to them a still further advantage.

As these middle age municipalities first attract the notice of history, the control of their affairs - by a return to the simplicity and equality of the original savage tribe - appears to have rested with the body of the citizens. The actual administration seems to have been usually intrusted to a council periodically elected, which councils, in after times, by processes to be hereafter more particularly pointed out, converted themselves into hereditary senates, or else into close corporations, electing their own members; thus concentrating the whole political power in themselves, and gradually stripping the mass of the citizens of any right to participate in it. Nevertheless, the idea of the political equality of all the citizens always 
survived, and forms a fundamental idea of modern democracy.

Along with this fundamental notion was associated, in the early days of these feudal age municipalities, another idea equally essential to modern democracy, and equally fundamental to the civilization of modern times - the idea, namely, of the honorable and praiseworthy character of productive industry, whether employed in agriculture, trade, or the mechanic arts; whereas, in the Greek and Roman municipalities, as well as among all nobilities, whether clerical or lay, ancient or modern, (with some slight exceptions, to be presently pointed out, in the case of those nobilities which may be called municipal or civic,) trade and the arts, especially all handicrafts, were and are looked upon as degrading, and the actual working with one's hands as fit only for the low and servile.

This latter of the two great ideas of modern democracy - that of the honorable character of productive industry, however humble - originated in, and, indeed, necessarily grew out of, the important fact, already mentioned, that there were no slaves nor serfs within these municipalities, but that all industrious occupations were carried on by freemen and citizens; and just in proportion as the municipal spirit has diffused itself, has this idea of the honorable character of productive labor also gained currency. 


\section{Section Sixth.}

Laboring Mass of the People. Approach, during the Feudal Times, to the Introduction into Europe of the System of Castes.

/ The three orders of the clergy, the nobles, and the burghers, or townspeople, who put forward, during the feudal times, pretensions, as against the monarchs, to a share, greater or less, of political power, included, we must remember, but a very small minority of the inhabitants of Europe. The great majority of the inhabitants were no longer chattel slaves, indeed, as in the days of the Roman empire, but still serfs, attached to the soil, and belonging with it to the monarchs, clergy, and nobles, and of course destitute of any political rights. $/$

The division of the Hindoos into the four great castes of priests, (Brahmins,) warriors, (Shatryas,) merchants, artisans, and agriculturists, (Vaisyas,) and mere laborers, (Sudras,) with the similar division in ancient Egypt, has attracted great attention as a very peculiar social phenomenon. Yet, as many traces of the feudal system, and especially of that main principle of it which vests in the government the ultimate title to all landed property, have been discovered in India, so it seems certain that Europe, at one time, was very near reaching that same division of castes which now prevails on the banks of the Ganges. At a certain period in the history of the feudal times, we find the population of Europe divided into the four very distinct orders of clergy, nobility, 
citizens, and serfs - classes which correspond exactly enough to the four great castes of the Hindoos. Had the progress of modern civilization been arrested at that point, and had the priesthood become hereditary, as the other classes already were, and as the priesthood is in most theocracies, and would have become in Europe but for the zeal of Gregory VII. to enforce the celibacy of the clergy, Europe might have become what India now is. Such is the singular connection of events that the ascetic doctrine of the meritoriousness of virginity, however absurd in itself, or to whatever evils it may have given rise, contributed, however, in an important degree, to the progress of modern civilization.

\section{Section Seventh.}

Development, in the Feudal 'Times, of the Idea of a Mixed Government.

The struggles for power and dominion which took place, during the feudal times, between the monarchs, the clergy, the nobles, and the burgesses, and especially the compromises which, at different periods, resulted from those struggles, gave a further and still more marked development to that idea of the division of power, and of a mixed form of government, of which the first notable historical instance had occurred in the case of the Roman commonwealth. Whenever the power of these different orders, or of any two or three of them, pretty nearly balanced each other, if any act was to be done which required the concurrence of the whole authority of the state, such as the 
enactment of a law to bind all classes, all these various depositaries of power must be made to act together. The barbarian conquerors of the Roman empire had brought with them the custom of a general assembly of the whole tribe to consult upon affairs of general interest, including the decision of controversies - a custom already referred to as preceding the establishment of any regularly-organized government, and which, in states forensically governed, is often maintained even after the government begins to take on a clearly monarchic form. These assemblies, of which the Champ de Mai of the Franks and the Polish Diet may serve as specimens, consisted originally of all the warriors of the conquering clan, presided over by the chief or king. But the general tendency - indeed, the dictate of convenience - was, gradually to limit the right of attendance; only the principal nobles appearing personally, the inferior nobles being present by a few deputies. These assemblies also early underwent another important modification - a consequence of the conversion of the barbarians to Christianity - in admitting the bishops and abbots to participate in their proceedings; and as the municipalities grew into importance, they, too, were finally admitted to appear by their deputies; and it was in this way that the English Parliament and the continental States General were gradually constituted. But the thing about these assemblies in which the idea of a mixed government was most fully developed was, that each order - the nobility, the clergy, and the burgesses - had to yield their separate consent to give validity to any proceeding; or, at least, that the separate assent was required of as 
many houses as the assembly was divided into, which, from a variety of circumstances, was different in different countries; to which was to be added the assent of the monarch also.

This, indeed, was a decided improvement upon the Roman usage of an independent legislative power vested in two assemblies differently constituted, and in which different classes predominated, whose direct clashing was only prevented by the veto power of the tribunes of the people - a method liable to, and in fact attended by, great practical inconveniences and abuses.

\section{Section Eighth.}

Mutual Relations of the several Orders during the Feudal Times.

The pretensions of the regular clergy to unite the whole of Christendom in one grand theocracy, with Rome at its head, having failed, they were presently reduced to join with the nobles in a struggle against the monarchs, in which, from taking the lead, they now came to play but a subordinate part. The nobles, though most arbitrary lords and tyrants within their own dominions, and violently opposing all attempts to restrain or diminish their authority there, still claimed, in virtue of this very opposition to any restraint upon themselves, to be the advocates and supporters of liberty. The sort of liberty which they advocated was, however, little else than a miserable mixture of anarchy and of tyranny on a small scale. Greatly, indeed, is it to be lamented that a name so 
cherished should, through long usage, have become associated, in the European and Americo-European mind, with notions so inconsistent with the public welfare.

The monarchs, on the other hand, while struggling to subdue the inordinate power of the nobles, and of the titled and the regular clergy, and to subject them to responsibility and control, claimed, and with much more reason, to be the friends of equality - a thing far better than any mere anarchical liberty; indeed, the only kind of liberty consistent with civilized life.

And so the citizens who composed the municipalities seem to have thought, since, in the political struggles of the feudal age, they generally sided with the monarchs, as finding them less oppressive than the noblés, and less inquisitorial and domineering than the clergy.

The municipalities, indeed, indirectly put into the hands of the monarchs that instrument by which they achieved their ultimate triumph, as well over the nobles and clergy as apparently also over the municipalities themselves. It was the free citiess of Europe that first, in modern times, employed mercenary troops ; and it was the growing wealth, of which the towns were the centres and sources, that furnished the princes of Europe with the means of keeping up mercenary standing armies. Having once obtained that instrument of power, the monarchs were able to assume, to a certain extent, the position of conquerors, and to reduce clergy, nobles, and municipalities to political insignificance; uniting, in fact, in their own persons, in the power they assumed of levying taxes 
by their sole authority, of conferring ecclesiastical benefices, and of appointing the magistrates of the municipalities, all the power that had formerly been distributed among the component parts of the assemblies of the states - which assemblies, indeed, at this period, ceased in many countries to meet at all, or when they did meet, were converted into mere instruments of the monarch's will.

\section{Section Ninth.}

Rise and Progress of the Political Power of the Legal Body.

The administration of justice is one of the principal functions of government. In the ancient republics, that body which possessed the controlling authority, whether an oligarchy, an aristocracy, or what was called a democracy, always reserved to itself the right of final judicial decision. During the feudal period, when the political power of the state became divided into several portions, the judicial power was divided at the same time, among the same parties. The greater nobles claimed the right of final judicial decision within their own domains. The clergy had courts of their own for the trial of members of their own order, and for settling questions relating to marriage and inheritance, of which they seized upon the jurisdiction as being connected with births and deaths, and having, therefore, something mystic about them. The municipalities also had their special civic courts for settling their local controversies. 
All that remained to the kings was the decision of disputes between noble and noble, nobles and municipalities, municipality and municipality, and so on; and even this jurisdiction was disputed - these parties claiming the right to make private war on each other. But this ruinous practice of private war, the monarchs, as they grew stronger, prohibited, establishing their royal courts - in France called Parliaments - for the settlement of these disputes. Similar courts were established in England about the same time, forming the basis of the existing system of English and American jurisprudence; their jurisdiction and forms of proceeding being fixed during the reign of Edward I. (A. D. 1272-1307.)

The establishment of these royal courts gradually raised up the lawyers to be a separate profession - a sort of corporate body, enjoying a high degree of consideration, and exercising a certain portion of political power. The various and often conflicting rights and privileges claimed by the kings, nobles, clergy, and citizens, resting occasionally upon charters or special agreements, between the kings on the one side, and the nobles, monasteries, and cities on the other, but oftener upon mere custom and tradition, made the law excessively cumbersome, complicated, and uncertain. Mere good sense and a spirit of justice were wholly inadequate to constitute a judge, since, in addition to these qualifications, a great apparatus of law learning became necessary. It thus happened that the body of the lawyers, from whom, of necessity, the judges of the royal courts had to be selected, came to be regarded, not only by the kings, but by the nobles and municipalities also, as the depositary 
of the knowledge of their rights, and by virtue of this veneration, and as the guardians of those rights, to attain to a certain power and authority in the state. The universities which sprung up during the thirteenth and fourteenth centuries, whose advice and opinions it was customary to ask and to urge upon clerico-politico-legal questions, were merely schools for the study of the scholastic divinity, and of the canon, feudal, and civil law.

The royal courts, of which the judges were appointed and removable by the kings, were, from the first, sufficiently favorable to the extension of the royal authority, coincident, for a time at least, with the extension of the authority of the lawyers; and with the extension also of peace, security, order, justice, and equality. Thus, in England, the courts of law, by their decisions respecting the effects of fines and recoveries, completely defeated the attempts of the nobility to render perpetual the entail of their estates; while the Court of Chancery, by its doctrines about trusts, got rid of a vast many restrictions on the alienation of landed property. Even the great measure of the emancipation of the serfs, accomplished throughout Western Europe during the thirteenth and fourteenth centuries, was greatly promoted by the zeal of the lawyers, who, in rescuing the rural population from the oppressive authority of their lords, amplified, at the same time, the jurisdiction of the monarchs and of the royal courts.

As Europe gradually advanced in civilization, these royal courts assumed, indeed, the high authority of modifying ancient customs to suit new circumstances, and of establishing, on the basis of right reason, new 
rules and customs where no old ones existed. So far as regarded the most important because most universally operating and permanent relations of society, those of the individual members of it to each other, subjects which, in those times, attracted very seldom, and only to very limited extent, the attention either of the monarchs or of the assemblies of the states, the courts of law became the chief legislators of Europe; and from that time to this, under pretence of expounding the law, - which is assumed to be a perfect and complete code, of which the different provisions are produced from the breasts of the judges, its sure though secret depositaries, as occasion arises, - the Supreme Courts of Europe and of the European colonies have been constantly making new laws; and in so doing they have accomplished, though not without much admixture of evil and error, a great work. This legislation, it must be admitted, abounds with flagrant defects, arising partly from the scholastic subtilties so fashionable in the feudal times, and so natural to that superficial state of knowledge in which words are mistaken for things; partly from the necessity the legislators were under of building upon a narrow and insufficient foundation of barbarous customs; and in a great measure also from the peculiar nature of their legislative authority, the existence of which they have strenuously repudiated and denied, even in the very act of exercising it. It has been, however, on the whole, far better legislation than could have been obtained from any other quarter; or indeed from the courts and lawyers themselves, had they not fortunately possessed and followed an admirable guide in the Code and Pandects of Jus- 
tinian. The Roman prætors, it is curious to observe, had found themselves obliged to legislate for the Roman people, in the very way in which the business of legislation is still carried on by the English and American courts - that is, by making new laws under pretence of expounding old ones. The Pandects are, in fact, but a compilation or abridgment of Roman reports of decisions, and of the opinions of eminent lawyers during a series of several centuries. With all its defects of execution, this collection contains a vast mass of legal principles, sifted by frequent discussions and tested by a long experience. The nobles naturally made a violent resistance to a system of jurisprudence, which, as it favored the power of the prince, and placed all the subjects on a level of equality, was hostile to their pretensions. Yet, either openly or covertly, that system, with some slight modifications and exceptions, has furnished, in all the relations of life and commerce, the civil code of Christendom - a result arrived at hardly less in Great Britain and her colonies than in the case of the continental states.

Though the royal courts, and the body of lawyers attached to them, were, in the first instance, active and efficient aids in extending the royal authority, yet they became, in process of time, after the growing power of the monarchs had humbled the clergy, subjected the nobles, and subdued the municipalities, the only remaining barrier against absolute power. The nobles, the clergy, and the citizens, though stripped of their political authority, were still acknowledged to have certain rights, guarantied by the laws, and which the courts and the lawyers upheld. In France, 
the Parliament of Paris, the supreme court of that kingdom, went still further; and as the monarchs had usurped the power of imposing new taxes by edicts of their own, without consulting the States General, so the Parliament of Paris strove earnestly to convert the custom which had obtained of registering these tax edicts on its records into a right of protest, and even of veto, by refusing to register such edicts as were, in their opinion, unreasonable or unjust. Even in England, - and the same is true in America, though the courts of law have been but too uniformly the supple instruments of power, the strenuous and obstinate defenders of all existing inequalities, under the respectable name of vested rights, yet there have always been found among the lawyers many of the adroitest, ablest, and most formidable opponents of arbitrary authority, and of antiquated abuses. Nor have those champions failed to derive great support to the cause they have thus espoused, from the accepted doctrine of the lawyers, that law, with all the respect which it pays to precedent, is, after all, a system of right reason and pure justice, of which the judges are only the expositors, and precedents merely the records - expositors and records which prove themselves in error whenever they are found irreconcilable with reason and right.

\section{Section Tenth.}

Distribution of the Functions of Government. Subdivisions of Authority.

The division of political power into several portions necessarily produces a distribution of the func- 
tions of government. Throughout Europe, during the feudal times, the power of declaring war, calling out the feudal militia, negotiating with foreign states, and carrying the laws into execution, together with a certain indefinite right of promulgating new.laws, was vested in the kings; the power of imposing taxes, and, by that means, of extorting from the kings enactments of general interest, ripening, in certain countries, into a full power of legislation, jointly in the kings and the assemblies of the states; while the power of deciding controversies, and incidentally, not only of interpreting the laws, but of making new ones, so far as mere domestic and mercantile relations were concerned, (involving often in the result great political consequences,) was exercised in the name of the kings by the supreme courts, assisted by the lawyers."

- It was this practical division of authority, perpetuated to our times under the British constitution, and imitated in those of America, which first suggested to modern writers on politics the idea of decomposing the functions of government into three elements, the executive, the legislative, and the judicial, and of intrusting each of these functions to separate and independent hands. Indeed, it has come to be a maxim very generally received among modern political writers, and which recent experience has

* A very curious topic - the veto upon the legislative power of the kings, exercised in England by juries, according to their original constitution - the faint shadow of which still keeps up the reputation of the jury as the "palladium of English liberty"- and the gradual loss of this right through the usurpation of the parliament and the royal courts - has been handled in a masterly manner in Lysander Spooner's recent Essay on 'Trial by Jury. 
tended to reënforce, that the liberties of a people can hardly be secure where these different functions of government are consolidated in the same hands. From the same source has also been derived the related idea of the division of the legislative authority among two or three bodies, acting as a check upon each other, and whose concurrence is required in all legislative acts.

It is no doubt both possible and desirable, and in fact essential to constitutional freedom, that the. several administrative functions of government should be exercised by different agents; and that even to a considerably greater extent than has ever yet taken place. It is impossible, however, to make a complete separation between these functions, since they run, imperceptibly, into each other. All these agents, too, ought to be mutually dependent upon some common superior, by whose superintending authority their. action shall be ultimately harmonized; as, otherwise, their mutual collisions and disputes might paralyze the efficiency of the government. During the feudal ages, this latter result was constantly occurring; and it was felt to be so great an evil as ultimately to produce, throughout continental Europe, a general acquiescence in the extinguishment of political liberty, by the concentration of all authority in the hands of the kings. 
DELEGATED AND REPRESENTATIVE AUTHORITY. 137

\section{CHAPTER VI.}

DELEGATED AND REPRESENTATIVE AUTHORITY.

\section{Section First.}

Delegation of Power in Monarchies.

- The chieftain, who, in process of time, and by the increase of the number of his subjects, finally becomes what we call a king, though he may, on important occasions, assemble the warriors and elders for consultation, yet usually exercises in person all the functions of government down even to that of executioner. This, however, is possible only so long as he remains the chieftain of a single tribe, camp, or village. When his authority includes several tribes or villages, he is obliged to share the functions of government with delegates, who act in his name and behalf.

There are two ways in which this may be done. He may either appoint persons to exercise separate and independent functions, according to the method above pointed out, - this man to be a judge, that man to be military chief; this man to be collector of taxes, and that man to have the custody of the revenue, or a portion of it, - or he may depute the entire powers of government, such as he himself possesses them, to be exercised within a certain district by a single individual. It is this latter and ruder method that uniformly prevails in monarchies which have sprung directly from the primitive chieftainey; the late independent chief of each successively conquered tribe 
- or some one of his family - being frequently continued as the subordinate ruler, under an obligation to pay tribute, and to render military aid to the superior chief. Wherever, in any monarchy, the former method prevails, it will probably be found to be only the continuation, or the copy, of some republican usage. Hence its prevalence in those monarchies distinguished as tyrannies, and secondary monarchies - that is, monarchies founded on the ruins of republics.

\section{Section Second.}

Delegated Authority in Republics. Representation.

IN all republics, at least in all aristocracies and democracies, an absolute necessity exists for intrusting the administrative functions of government to delegated agents. It is impossible for any large number of persons to participate in any consultation to which" their personal presence is necessary. Any assembly which consists of more than a few hundreds loses the power of deliberation, and degenerates into a mere mob, in which the conception of the moment becomes contagious and ommipotent, and every thing is carried by the noisiest and most violent. But, though the obvious impossibility of carrying on the executive functions of government, except by intrusting them to the separate management of one or a few individuals specially appointed for that purpose, has led, in all republics, to the election of executive magistrates, the ruling body, whether aristocracy or democracy, has always shown 
great reluctance to give up the personal exercise of judicial and legislative authority. In all the ancient republics we find no instance of an elective senate or council for legislation. Their senates seem always to have consisted of the wealthiest members of the community, or of those who, by reason of their birth, their priestly offices, their greater experience, or their superior abilities, were able to exercise a power not delegated, but original in themselves. These ancient senates were, in fact, instances, not so much of the delegation of authority as of the aggregation of it in certain individuals, through the influence of the primary or secondary elements of power.

The assemblies of the delegates of the allied Greek cities of Asia Minor, and of those which belonged to the Achæan League, hardly form an exception, since those assemblies were rather congresses of ambassadors than proper legislative bodies.

In those ancient republics, in which prevailed that form of government called by the Greeks a democracy, the highest acts of power, the enactment of laws, and the decision of the most important controversies, were reserved for the general assemblies of the citizens - assemblies, for the reasons above stated, not very competent to the judicious and deliberate exercise of any such functions. In fact, they were perpetually guilty of acts of precipitate folly and injustice, such as brought that form of government into very bad esteem with all the more considerate of the Greek historians and philosophers.

The Romans made one important step towards overcoming the physical difficulty of permitting large 
numbers to participate in legislative and judicial acts, by dividing their assemblies into distinct bodies, centuries, or tribes, each of which met and voted by itself. But in the later days of the republic, when the number of those entitled to the right of citizenship was greatly increased by the admission of all the Italian cities to that privilege, this contrivance no longer answered any good purpose, and the assemblies of the people became perpetual scenes of confusion, uproar, and violence. The simultaneous meeting, in the forum, of all the tribes and all the centuries, was, indeed, a great drawback upon the efficacy of this Roman method.

As we are indebted to the municipalities of the middle ages for the first idea of a democratical equality extending to all the community, so it seems to have been in those municipalities that the application was first made of the only effectual means whereby the mass of a community can be enabled to exercise political power without tumult or violence; namely, the delegation, not only of the executive, but also of the legislative and judicial functions of government, to certain agents specially elected at stated periods for those purposes, and responsible to those who elect them for the proper discharge of their several duties. But, though the practice of legislation through the medium of representatives seems first to have been introduced in the local municipal governments, that idea presently received a more extended application in the constitution of the assemblies of states in the middle ages, in which, though the greater nobles and clergy sat in person, the inferior 
nobles and clergy, not less than the municipalities, appeared by their elected delegates. So far as relates to the decision of minor controversies, the same idea had been earlier carried out in the Greek and Roman republics, and among the Saxons and other German tribes, in the selection by lot or otherwise of a certain select number to act as judges or jurors, (originally the same thing,) instead of the general assembly of the city or canton.

But it is in the United States of America that the principle of representative government has been most extensively and successfully applied. The town assemblies of New England, including all the legal voters, exercise, indeed, a certain limited power of taxation and legislation; but, with this exception, the entire functions of government, as well for the municipal districts as for the states and the Union, are vested in certain officers and bodies, elected (except a part of the judicial officers) for short terms, and, what, perhaps, tends still more to the prevention of abuses, for very limited ranges of authority; so that any of these bodies or officers, attempting to stretch their jurisdiction, soon find themselves in conflict with their coöperators in the government, who thus act as important checks upon and supervisors over each other. 


\section{CHAPTER VII.}

PROCESS BY WHICH DEMOCRACIES ARE TRANSFORMED INTO ARISTOCRACIES, OLIGARCHIES, TYRANNIES, AND SECONDARY MONARCHIES.

Althougin the municipal spirit and democratical ideas have, in our time, become very much diffused, forming the basis, indeed, of all the popular movements now, and for three quarters of a century past, going on throughout Christendom, it nevertheless has happened that almost all of those feudal age municipalities in which that spirit and those ideas had their < origin long since lost all tinge of democracy in their own interior administration; it being entirely superseded there by oligarchy or tyranny. The process by which this remarkable result has been reached constitutes an important topic of inquiry.

When we compare the original tribe or clan, at the moment of the first appearance in it of an organized - government, with the original condition of the democratic municipality, we perceive some close resemblances and some obvious differences. In both there exists a very great equality among the members, especially as to wealth, and in both the authority exerted by the government is very limited. These are the resemblances; and the differences are not less striking. In the original clan, the government, as it gradually takes on an organized form, assumes also a monarchical character. He who possesses the great- est influence over the determinations of the tribe, as that influence increases, tăkes more and more upon 
himself the office of deciding public matters and private controversies, without thinking it necessary to ask counsel or advice of the assembled community, or of the elders. Power is thus gradually aggregated and centralized, till the control passes from the majority, the original depositary of it, into the hands of one man - the chief or king. We have seen how the introduction of domestic slavery, by which the practice of tyranny is familiarized, tends to give new vigor to the authority of the chief; and how the same result is still further promoted by the increased accumulation of wealth, a great amount of which always tends to concentrate in the chief's hands. This monarchical government, on the failure of the royal family, is apt to change, as we have seen, to an oligarchy, thence to an aristocracy, thence to that extended kind of aristocracy which the Greeks called a democracy, from either of these forms to a tyranny, and from tyranny back to oligarchy or aristocracy, and so on ; $<$ alternating between tyranny, oligarchy, and aristocracy, with perhaps an occasional, but generally very short, restoration of the democratic form, till the state falls a prey to some conquering neighbor. Chattel slavery, so long as that root of political inequality continues to exist, seems to make it impossible for a community to escape out of this charmed circle, or to. take on the true democratic character.

In the municipal democracy, on the other hand, the government, from its very commencement, assumes a representative form, and the legal equality of the citizens is long preserved. Those who desire authority are obliged to exercise it through the medium of a personal influence, based on the primary and second- 
ary elements of power, over the opinions and votes of their fellow-citizens. The institution of chattel slavery not existing, the idea of arbitrary and cruel exertions of power is abhorrent, and always reniains so, to the feelings of the community. Only by slow degrees, in such a state, is despotic authority able to establish itself. The government, in a way we shall presently point out, changes gradually and almost imperceptibly into an aristocracy, which becomes, perhaps, an oligarchy. To this a tyranuy finally succeeds, which, though often harsh and cruel towards the aristocracy, is generally, at least upon its.first establishment, mild and favorable towards the mass. Frequently, indeed, the multitude, sick of aristocratic insolence, lend their aid to the change, rejoicing in the humiliation and subjection of those by whom they have been themselves humiliated and subjected.

When a monarchy has thus become established over what was once a municipal democracy, another cycle of changes begins. 'The monarchy, on failure of the royal family, or by revolutionary violence, - for the recollections of republicanism long survive, - may - change again to an oligarchy, or to an aristocracy, which, by continually expanding itself, may end, at length, in a new democracy. Or this process may go on pending the existence of the monarchy; the king being gradually stripped of his power, which passes into the hands of a number of his nominal subjects; and this number may go on increasing till the government becomes again an actual democracy. The nonexistence of chattel slavery in such a community except, indeed, its place be supplied by the spirit of caste, (the influence, that is, of traditional respect,) or 
by mystical ideas - produces, in fact, a constant tendency in that direction.

In the original clan, the possession of power leads to accumulation of wealth in the hands of those who possess power; which accumulation of wealth reacts to produce an increase of power. In the municipal democracy, the accumulation of wealth leads to the possession of power; which possession of power is employed as a means of accumulating wealth. But this is a process which does not go on long, nor far; for the aristocracy or the tyrant under whose control the community thus falls, like the greedy woman in the fable over-eager to increase her stores, soon kills, by impolitic exactions, the goose that lays the golden egg; the whole community, governors as well as governed, gradually, under the influence of bad government, sinking to poverty.

The accumulation of wealth, in the original clan, takes place, as we have seen, by the introduction of chattel slavery, - the case of some theocratic governments, perhaps, excepted, in which the influence of mystical ideas is made to stand in the place of it, and by plunder and conquest, to which, indeed, slavery owes its origin. In the municipal democracy, the accumulation of wealth takes place, at least in the first instance, by industrious occupations; and, as these occupations are equally open to all, somewhat of the original equality of wealth is long preserved. But commerce - especially that commerce which is not confined to regular channels, but which has the character of speculation and adventure - tends to produce marked inequality of wealth; and this wealth, preserved and transmitted in certain families, gives 
to those families a preponderating influence in the community. It results from this influence that the members of the legislative council and the principal executive officers are generally selected from among a limited number of wealthy families, who soon come to consider themselves, in consequence, as having a sort of right of property in the government, and to form plans for securing the whole political power.

The first step in this career commonly is, to diminish the frequency of elections; to which, as the same persons are constantly reëlected, the voters are the more readily induced to consent. Thus the members of the legislative body, and perhaps the principal executive officers, from being annually clected, are first chosen for a long term of years, and then for life. Next, advantage is taken of some tumult or riotand the seldomer public assemblies are held, the more tumultuous they are apt to be-to abolish popular elections altogether, as inconsistent with the public peace. The council assumes the office of filling up vacancies in its own body, and the election, also, of all the magistrates; and the late municipal democracy is thus converted into what is called a close corporation. As power thus concentrates in a few hands, those who possess it make use of it to secure to themselves a monopoly of the more profitable branches of trade. It is, indeed, to the great disjunction of interests produced among the citizens of the middle age municipalities by the spirit of monopoly, and the grasping at exclusive privileges by different guilds, companies, and associations, in direct violation of that idea of equality which lies at the bottom of the municipal democracy, that we must ascribe a great 
influence in the conversion of those governments into aristocracies and oligarchies.

From a close corporation, possessing the right of filling all vacancies in its own body, it is an easy and customary transition to an hereditary council or senate. Thus we see erected, upon the ruins of democratical equality, a civic nobility in favor of which the idea of property in power and traditionary respect presently begin to operate. If the municipality, as frequently happens, becomes engaged in wars, and makes conquests which it does not incorporate into itself, but governs as subject provinces, the concentration of wealth and power in a few hands proceeds at a much more rapid rate. Those who have the administration of these subject provinces always employ the arbitrary power intrusted to them as a means of accumulating wealth; while the troops which the municipality is obliged to maintain therein are always highly dangerous to its own liberties.

When a single family, by reason of its superior wealth added to superior talent, became able to overtop all the rest, the civic aristocracy, by which the original . municipal democracy had been superseded, is itself superseded by a tyranny, established, and, in màny <cases, sustained, by the basest arts and the most detestable cruelties towards the late ruling aristocracy; but, in general, if it does not alleviate, certainly not aggravating the yoke of the already subject mass.

The revolutions of the Italian republics, especially of Venice, Genoa, Milan, and Florence; of the Flemish and German free cities; of the Swiss cantons; and of the united Dutch provinces, - will serve abundantly to verify all these observations. 


\section{CHAPTER VIII.}

DIFFERENCE BETWEEN PATRICIAN AND CIVIC ARISTOCRACIES.

\section{Section First.}

Comparison of Civic and Patrician Aristocracies.

There is one important particular in which the aristocracies which spring up in, and succeed to, municipal democracies, and which, for the sake of distinction, we have called Civic Aristocracies, differ from the aristocracies which succeed to the organized monarchy - a difference which gives to civic aristocracies a power much more firm and lasting. Both admit the hereditary principle; but aristocracies of the latter kind, which may be distinguished as Patrician, - since they rest, in a great measure, upon certain traditional genealogical considerations, form, as it were, a separate caste, to which the idea of intermarriage with the plebeian vulgar is utterly abhorrent, as tending to destroy that real or supposed peculibrity of blood to which the patrician order owes a large part of its consideration and influence. The civic or plebeian aristocracy, on the other hand, owes its influence mainly to its wealth, which it is ready at all times to recruit, not only by intermarriages with rich heiresses of the vulgar sort, but also by admitting into its ranks all the more wealthy and able of the vulgar order, whom it thus converts from its most dangerous enemies into its warmest and most devoted supporters. 
But, notwithstanding this difference in their origin and character, it not unfrequently happens that a patrician is gradually transformed, or rather absorbed, into a civic aristocracy - a transformation which occurred in many of the Italian republics of the middle ages, and in some of the Swiss cantons; the old nobility residing in the rural districts attached to the towns being induced or compelled to accept the right of citizenship, and to mingle in one body with the citizens. And this same process is now going on, if indeed it may not be said to be already completed, in England; though in that country a curious jumble still exists of patrician and civic ideas.

It is no doubt true that the unequal distribution of wealth has had a great deal to do with the production . of patrician as well as of civic aristocracies. But the wealth of patrician aristocracies has been mainly founded upon conquest, plunder, and the possession of chattel slaves or serfs; while their power has been mainly sustained by their superior personal skill in the use of arms, which they have seldom intrusted to the hands of the subject class. Such aristocracies have always despised all industrious occupations; they have regarded the terms base and mechanical as synonymous; and have looked upon trade, and still more upon all handicraft arts, as mean and degrading. Such were the sentiments of the Dorian Greeks, of the Romans, and of all the feudal aristocracies of Europe. They considered war and plunder the only occupations fit for gentlemen, and regarded any intermixture or amalgamation with the laborious class, whether by marriage or participation of rights, as a thing not to be thought of. Like the American slave- 
holders of the present day, though they selected their mistresses from among the most comcly of the wives and daughters of the inferior order, to have taken women of that order as their wives would have been regarded as an intolerable degradation. The story of Rousseau's Nouvelle Heloise, and indeed of a vast many of the novels and plays of modern Europe, turns upon this bar of separation between the patrician and civic orders.

Civic aristocracies, on the other hand, having ac- cumulated their wealth by commerce, and by industrious occupations, still continue to hold those occupations in a certain patronizing esteem; to afford protection and countenance to them; and, as has been already remarked, not merely to admit but to welcome into their order all of the lower ranks who amass wealth, or rise to high positions, civil or military. These civic aristocracies make, indeed, a certain approach to democracy in the circumstance that, although they do not admit equality of political rights, they yet allow to the excluded a chance or expectation of obtaining a share of those rights. In fact, these civic aristocracies are capable, by a gradual extension of the circuit of the privileged order till it finally admits the whole community, of passing into democracies by almost insensible degrees. Yet they : also may, and often do, proceed in the opposite direction; and by multiplying the obstacles to admission into their ranks, change, by degrees, into patrician aristocracies. 


\section{Section Second.}

Wealth as an Element of Power. Moneyed Form of Social Slavery.

'Ir appears, from these considerations, that wealth may justly be regarded, not indeed as the sole, but still as altogether the most important, element of political power, able to purchase up the services of strength, skill, sagacity, force of will, activity, courage, knowledge, eloquence, and, to a certain extent also, the coöperation of the influence of virtue, of mystical ideas, of hereditary respect, and of the idea of property in power. In addition to this aggregation of influences, wealth affords also great facilities for combination, which easily takes place among a few rich, whom the smallness of their number and their freedom from the engrossing necessity of providing daily bread for themselves and their families enable to act together with energy and effect. /

Even after the members of a civic aristocracy have grown too delicate and refined any longer to bear. arms themselves, employing their whole lives in one ceaseless round of dissipations and amusements, their wealth still enables them to hire, from among that large portion of the community whom their policy keeps ignorant as well as poor, and whom ignorance and poverty have made abandoned and ferocious, a standing army of mercenary soldiers, mere machines in the hands of a body of officers, themselves selected from among the offshoots of the aristocracy, and themselves also dependent on their pay for their bread; 
a certain portion of the depressed multitude being thus fed and trained for the express purpose of shooting down, under aristocratic guidance, any of their own class who may attempt, by force, to resist or to throw off the oppressions of the rich.

The gift of public employments, and still more the control which the rich possess over all private lucrative employments, and the temptation thus held out to all the active and ambitious poor of obtaining, by the accumulation of wealth, admission for themselves into the privileged order - these means enable the few rich to seduce and buy up the greater portion of those among the mass who exhibit signs of superior energy and talent; so that the mass, for the most part, are left without leaders, or are constrained to take as such certain outcasts and renegades from the aristocracy, whom extravagance or utter profligacy has ruined, and who, as a last resort, take up the trade of patriots and demagogues. The notoriously bad character of these men, and the regular custom, which establishes itself among poor men of talents, of setting themselves up as leaders of the mass and vindicators of popular rights, in order to make a show of their abilities, and so to compel the rich to bid a high price for them - these things throw a shade of suspicion over the motives of all who exhibit a disposition to favor the rights of the people; while the leaders of the aristocracy, not seeming to contend so much for their own individual benefit as for that of a large body of men, their own order, are able not only to escape all suspicion of self-seeking hypocrisy, but even to set up a claim to disinterestedness and magnanimous public spirit. 
The establishment of a state clergy, who receive stipends from the public revenue, or who are sustained by the government in the possession of certain lands, tithes, and other property, and still more the introduction of that "voluntary system," as it is called, which makes the clergy directly dependent for a livelihood on the mere benevolence of the rich, bring the influence of mystical ideas to the support of the aristocracy of wealth. Religious establishments are generally the remains of an independent, and what, perhaps, was once a controlling mystical aristocracy, but which, by the decline in the influence of mystical ideas, has lost the greater portion of its power, and has fallen into dependence upon the aristocracy of wealth, from which it borrows support, at the same time that it lends it. Thus, in Scotland, for instance, the established Presbyterian clergy, once a substantive power in the state, and but recently defeated in a new attempt to become so again, is kept up and paid by a few rich landholders, for the purpose of preaching contentment, submission, and obedience to the impoverished mass, and consoling them with promises of future happiness and glory for present pains, privations, and oppressions.

Paley, in the first part of the third book of his Principles of Moral and Political Philosophy, in the chapter entitled Of Property, describes, in the following graphic manner, the existing social state of Europe: "If you should see a flock of pigeons in a field of corn, and if, instead of each picking where and what it liked, (taking just as much as it wanted and no more,) you should see ninety-nine of them gathering all they got into a heap ; reserving nothing for them- 
selves but the chaff and the refuse; keeping this heap for one, and that the weakest, perhaps worst, pigeon of the flock; sitting round and looking on all the winter, while this one was devouring, throwing about, and wasting it; and if a pigeon, more hardy and hungry than the rest, touched a grain of the hoard, all the others instantly flying upon it and tearing it to pieces; if you should see this, you would see nothing more than what is every day practised and established among men. Among men you see the ninety and nine toiling and scraping together a heap of superfluities for one, (and this one, too, oftentimes the feeblest and worst of the whole set, a child, a woman, a madman, or a fool;) getting nothing for themselves all the while but a little of the coarsest of the provision which their own industry produces; looking quietly on while they see the fruits of all their labor spent or spoiled; and if one of the number take or touch a portion of the hoard, the others joining against him and hanging him for the theft."

Were the above a quotation from Louis Blanc or Pierre Leroux, it would, no doubt, be set down as rank socialism. In fact, it is but a paraphrastic anticipation of that celebrated dogma of Proudhon Property is theft. But, however faulty in theory, it is correct enough as a picture; nor can the ninetynine plucked pigeons be expected to detect a fallacy accepted for truth and science, not by Archdeacon Paley alone, but by almost the entire school of modern political economists.

Continual exposure to pains, especially to such as are truly or falsely ascribed to human contrivance or agency, has a natural and necessary effect at once to 
diminish the susceptibility to the sentiment of benevolence, and to call into action the sentiment of malevolence. What cause then for wonder if the mass of the people, trodden down and ridden over by a proud and splendid aristocracy, the privations of want, and the hardships of labor, made vastly more painful by the spectacle constantly before them of overflowing wealth, abundant leisure, and the most profuse luxury - what wonder, if, under this discipline, the mass of the poor are filled with bitter hatred of their rich rulers, becorne greatly demoralized, lose all respect for the rights of property, of which they themselves have so little enjoyment, and are only kept under by the severest laws and a constant display of military power?

The demoralizing effects of chattel slavery, whether domestic or predial, are very generally admitted. Yet it may be considered a doubtful question if the moral results that follow from that sort of servitude, whether as respects the masters or the slaves, are at all more disastrous than the results of this new moneyed form of Social Slavery, so much more aggravating than the earlier mystical form of it, by which the great mass of the people, throughout a large part of Europe, are subjected to the severest and most hopeless labors seemingly for the exclusive benefit of a wealthy few.

So solid, however, is the basis upon which the power of civic aristocracies rests that there would be little hope for the mass of the people did it not fortunately happen that such aristocracies become, from a variety of causes, almost always divided into two or more factions, which struggle with each other for the control of the state. It is usual for the defeated faction to attempt to strengthen itself by professing great 
zeal for the mass of the people; nor does it hesitate to purchase favor and support by promises of social reforms, and of the extension of political rights, too frequently forgotten when, by these and other means, the control of affairs has been finally obtained.' Yet out of these struggles some extension of political rights inevitably results. The mass of the people, at least, acquire a participation in that liberty of assemblage, of speech, and of the press, - among the most substantial and effective of political privileges, - which the faction of the "outs" for the time being always struggles to secure for itself, as essential means towards regaining a political predominance.

Let us add, too, that, with the progress of knowledge and thought, the fact comes to be plainly perceived that to raise the mass of the people to a more equal participation in the goods of life is essential to the further progress of civilization; while, with the growing force of the sentiment of benevolence, which acts always with the most energy among those in comfortable circumstances, a disposition springs up to contribute, by all feasible and promising means, to a result so much to be desired. The disposition, for example, which has so strongly developed itself in England during the last thirty years, to ameliorate the condition of the socially-enslaved laboring classes of that country, cannot but be regarded as a most hopeful omen for the future.

From the above considerations, it necessarily fol. lows that the natural and artificial laws which regulate the accumulation, and especially the distribution, of wealth are of the highest importance as regards - morals, politics, indeed human happiness in general. 
The particular investigation of those laws belongs to the Theory of Wealth. It is sufficient to observe here that (great and permanent inequalities of wealth always result from and are kept up by plunder, monopoly, entails, the exclusive possession of public employment and handling of public money, and that, when the practice of plunder ceases, and all special privileges are done away with, the tendency always is towards a certain degree of equalization.

14 


\section{chapter IX.}

ADDITIONAL ILLUSTRATIONS FROM HISTORY:

\section{Section First.}

\section{What we call Universal History.}

OF the ten or twelve distinctly-marked varieties of the human family by which we find the globe at present possessed, only two - that known as the Tartar and that which is called the Caucasian variety - have - preserved any written memorials of their history. The other races have become known only through their contact with these two, and, with respect to most of them, that knowledge goes back but to quite a recent period.

The contact between the two great historical races, separated as they have been by the vast mountain chains and great barren steppes of Central Asia, has been only slight and occasional; and, except a few violent movements from east to west, and of late from west to east, a few points where they have touched and partially intermingled, a few common influences which have been brought to bear more or less strongly upon both, the development of each appears to have been unique and distinct.

It is a curious fact that the written historical documents of the Chinese date back to nearly the same period with those of the Greeks; Confucius, the father of Chinese history, as well as philosophy, having been born a few years after the death of Solon. 
Such, however, is our very imperfect knowledge of Chinese writings, and, it is to be feared, the immature character of Chinese literature, which, in the long period since the age of Confucius, appears to have made no real progress, that we can expect little light from this source upon any political question. What we call Universal History is limited, at least for the present, to the history of the Caucasian race; the. other races appearing on the scene only as they come into contact or collision with this.

Before written documents can begin to exist, - and without written documents there can be nothing like chronological history, - it is evident that a great advance must already have been made in civilization; and, if this advance took place by spontaneous development from the original savage tribe, in some favored spots, and under circumstances peculiarly favorable, spreading thence to other communities less favorably situated, who learned and imitated what they never could have invented, it may well be supposed to have corsumed a goodly period.

At the point of time at which chronological history may be said to begin, we find existing great cities and extensive empires, in the arts of life, and in scientific knowledge, not very materially behind the utmost limit to which, till within three or four centuries past, the race has attained under the most favorable circumstances.

This beginning of chronological history may be fixed at the commencement of the Persian empire founded by Cyrus, to which the date is here ascribed of 550 B. C. Not that this date can be given with any real precision, but because an even year in the 
middle of a century serves to aid the memory by facilitating subdivisions of the subsequent period.

It is possible, indeed, to trace back, by certain memorials which they have left behind them, certain portions of the Caucasian race to a period far anterior to that of the foundation of the Persian empire - an empire itself formed by the conquest, and the union under one prince, of many ancient kingdoms and commonwealths - Indian, Assyrian, Syrian, Egyptian, Lydian, Phœnician, Greek, \&c. But this portion of our historical knowledge, consisting, as it does, of a few facts, and of a vast quantity of conjectures founded upon them, - conjectures still very immature and unsystematic, - must be placed under the head of Antiquities - of which the materials are, first, some few written documents, such as the Iliad and Odyssey; some fragments of the Greek lyric poets, to which we may add the labors of certain Greek scholars of the Alexandrian school, (who possessed those materials, such as they were, in greater abundance than we do,) to construct out of them a systematic chronology; portions of the sacred books of the Hebrews, Persians, and Hindoos, older than the date above fixed upon for the commencement of chronological history; the inscriptions on the ancient monuments of Egypt, Nineveh, \&c., which it is now so laboriously attempted to decipher, and not altogether without success; those monuments themselves, and the sculptures, pictures, and other works of art found in connection with them; and, finally, the analogy of languages, which carries us back to some remote period when the common ancestors of the Greeks, the Germans, and the superior castes of the 
Hindoos fed their flocks on the same plains, and formed together but one community.

All this period of antiquities, running back for indefinite ages, however curious and interesting on several accounts, is of little importance to the political student, whose attention must be chiefly fixed on the period of chronological history. Indeed, it is only from a thorough knowledge of the chronological period that we can hope ever to bring into connection such few fragments and indications we have of previous times, so as to construct a sort of conjectural history out of them - as the geologists, by the careful study of existing phenomena and comparison of them with the relics of the past, conjecturally reconstruct for us the ancient globe.

Even with respect to that period, which we have designated as chronological, including twenty-four centuries from our assumed era of the Persian empire, down to the year 1850, our knowledge of different portions of it must obviously be very different; and as to many counties and nations, even some which have played a very distinguished part in history, the period of their antiquities must be brought down to a much later date.

To assist the memory, and to enable us the more easily to pass under review what we know of political history, let us divide our twenty-four chronological centuries into three periods of eight centuries each - subdivisions which we designate respectively as Ancient, Middle, and Modern. 


\section{Section Second.}

\section{Ancient Period.}

WE include under this period the eight centuries from B. C. 550 to A. D. 250, or from the foundation of the Persian empire to the reduction of the Roman empire to one homogeneous body by the extension, to all the subjects of it, of the rights of Roman citizenship - an era marked also as the commencement of a new order of things, by the first invasion of the barbarians, by whom the Roman empire was finally overthrown; and still more remarkably by the first serious and general persecution of the Christians the beginning of that great struggle between the civil and ecclesiastical powers which has since played so serious a part in European affairs.

This ancient period may again be divided into two sub-periods of four centuries each, of which that from B. C. 550 to B. C. 150 may be distinguished as Grecian, and that from B. C. 150 to A. D. 250 as Roman.

The Grecian sub-period may again be subdivided into the Age of the Greek Republics, B. C. 550-350, and the Age of the Greek Kingdoms, B. C. 350-150. But, as we have already had occasion to speak at considerable length of both these ages, so far as the history of the Greeks is concerned, it will not be necessary to resume that subject here.

It was soon after the beginning of the second of these ages - the age of the Greek kingdoms - that the Roman republic, of which the early accounts must be 
regarded as partly fabulous and partly conjectural, begins to become visible above the political horizon. Commencing with the complete and final subjection of the Latins on the immediate banks of the Tiber, the Romans proceeded, in the next three quarters of a century, to the conquest of all Italy south of the Rubicon, including the ancient Greek cities planted on either coast. This extension of empire was soon followed by a struggle with the powerful commercial republic of Carthage - of the internal policy and political history of which we are unfortunately so ignorant - for the possession of Sicily; which finally passed, A. D. 241, with all its ancient Greek cities, under the Roman rule. In the course of the next hundred years, not only were Cisalpine Gaul, (Italy, that is, between the Rubicon and the Alps,) and the eastern shore of what is now called the Gulf of Venice, added to these conquests, but a second desperate struggle with Carthage - during which Italy was invaded by Hannibal, and the Roman power shaken to its very centre - resulted in the complete triumph of the Romans; in the confirmation of their authority in Italy and Sicily; the subjection to Roman power of the provinces which the Carthaginians had conquered in Spain; and, finally, in the eapture and destruction of Carthage itself, and the absorption by Rome of its African dependencies. The Greek kingdom of Macedonia, which had been drawn into the struggle as an ally of Hannibal, and all the cities and republics of Greece, shared also a similar fate. Even a large part of the Asiatic Greeks fell at the same time under direct Roman influence, being ruled, at 
first, by princes under their patronage, and becoming presently Roman provincials.

The Roman history during this period ought to be fuller of political instruction than even the preceding age of the Greek republics, dealing as it does with larger communities and masses of power. But, limited and insufficient as our means are for obtaining a true idea of the history of the Greeks, as regards this first historical portion of the Roman annals, our materials are still less satisfactory. Nothing can supply the loss of the greater part of the history of Polybius. We shall strive in vain to gather from the rhetorical pages of Livy any clear idea - which he himself probably did not possess or even aim at - of the relations of Rome to the conquered cities and states of Italy, upon which the fate of Hannibal's invasion so essentially depended; or, indeed, of the real political constitution of Carthage; or even of that of Rome itself. The true political history of this whole period, hardly less than that of the primitive Roman state, can in fact be little more than guessed at.

The four hundred years, designated above as the RoMan sub-period, - B. C. 150 to A. D. 250, - may also be subdivided into two ages, each of two centuries; the first of which, that from B. C. 150 to A. D. 50, may be distinguished as the Age of the Roman City, and the other, A. D. 50-250, as the Age of the Roman Empire. For the first of these ages - to the commencement of which belongs indeed the final subjection, already mentioned, of Carthage, Macedonia, Greece, and Western Asia Minor - materials are more ample. Yet, in spite of the meritorious labor 
of critics and antiquarians, who have pressed into the service every hint and scrap any where to be found, though the chronological series of events is pretty exactly ascertained, as to their springs and causes, as well as to the actual political character of those events, we remain often very much in the dark.

For the whole eight centuries of what we call the ancient period, our authorities are in truth exceedingly limited, giving to them so much of the character of the still more ancient ages, that a great deal must be supplied by conjecture. For the greater part of that period no contemporary documents exist, except a few poems, orations, and letters ; while of the historical writers, on whose relations we are obliged chiefly to depend, very few are even the original compilers, from good or bad materials, of the accounts which we have; these accounts being derived, to a great extent, from fragments of compilers at second or third hand, of whose judgment as to testimony, and much less of whose scientific knowledge of politics, it is impossible to form any very high estimate. They seem, indeed, often to have regarded forms of expressions and rhetorical effect as of at least quite as much importance as the matter which they had to communicate. 'There are no other such writers in all antiquity as Thucydides and Polybius - of the latter, we possess but a fragment; - and even they, with alf the light which they throw upon ancient history, suppose their readers to possess a great amount of information, the lack of which can only be supplied by guesses more or less plausible.

Hence it follows that any political conclusions, founded solely upon Greek and Roman examples, 
are to be received with great caution. In fact, it is only a thorough knowledge of the general theory of politics that can enable us to construct, from such fragments as we have, any thing like a tolerably probable skeleton of the history of the ancient period - a theory, however, to which the recorded history of the Grecian and Roman republics must be admitted to contribute a very important aid.

\section{Section 'Third.}

\section{Middle Period.}

The eight centuries from A. D. 250 to A. D. 1050, which we have designated as the Middle Period, will also admit (to aid the memory) of a division into two sub-periods, each of four hundred years, of which the earlier, from A. D. 250 to A. D. 650 , may be distinguished as Barbarico-Christian, and the other, from A. D. 650 to A. D. 1050, as Barbarico-Moslem.

There are two things which these two sub-periods have remarkably in common : first, successive barbaric invasions, sweeping away and almost, or quite, destroying, a preëxisting civilization, built on too narrow and weak a basis to be able to resist these impetuous torrents; and secondly, the vast force of mystical ideas. In the earlier sub-period this force is exhibited; not only in the triumph of the Christian church - which had originated, in the two previous centuries, from most obscure and feeble beginnings - over the old superstitions, the old philosophies, the laws, and the civil authorities of the Roman empire, which united 
strove vainly to suppress it; but in its triumph also over the invading barbarians, by whom the Western empire was overwhelmed. In the latter period we may observe this same mystic influence, not gradually developing itself by the coöperation of many individuals, through long periods of time, as in the case of the Christian church, but welling forth, as it were, a full and foaming torrent from the soul of a single individual, and inspiring into the nomadic barbarians, who successively became its instruments and depositaries, not only the strength and courage to overrun and subdue those provinces of the Roman empire which had hitherto repelled invasion, but imparting to them the mental energy to triumph over, to tread out, and almost or quite to extinguish, in the countries of which they became the masters, the Christiąn church itself, not less than other more ancient religious organizations; making it, indeed, for ages, a doubtful question, whether Mohammedanism, instead of Christianity, should not overspread the world.

A vast deal of important political knowledge is, no doubt, to be obtained from the study of the history of this middle period. Nor, although it includes the times commonly designated as the Dark Ages, is it by any means so deficient as the more ancient period which precedes it in original and contemporary documents ; at least in so far as relates to the history of Christendom. The multitudinous volumes of the Christian fathers, the codes of Theodoric and Justinian, a considerable number of barbaric codes, and many contemporary annalists in a variety of languages, belong to these times. But it must be confessed, that, 
in general, these writings are very little inviting, and that the direct contributions which they make to philosophy of any kind are exceedingly small. The whole period, indeed, may be aptly termed Dark, as one upon which the mind, ever anxious for progress and improvement, loves not to dwell; of which the distinguishing feature is a succession of barbaric invasions, threatening to sweep away all that had been done for the elevation of the race in previous periods, to obliterate ancient knowledge and art, and to reduce the whole human family to a common level of ignorance, poverty, and superstition - a disagreeable scene, over which the imitative and imperfect science of the courts of the caliphs, and Charlemagne's ineffectual struggles after a new Roman empire, throw but a few faint and ineffectual glimmers of light.

\section{Section Fourth.}

\section{Modern Period.}

The period of eight centuries from A. D. 1050 to the present moment, distinguished in our division as the Modern Period, admits also of an equal division into sub-periods, which may be aptly enough designated as Feudal and Commercial.

The first two centuries of the feudal ages, from A.D. 1050 to A. D. 1250 , constitute, as it were, a prolongation of the preceding period. The crusades, and the attempt at a theocratic monarchy over Europe in the person of the pope, supported by the religious orders, were its leading events; and it may, in consequence, 
be well enough distinguished as the Age of the Priests. The following age, - the latter half of the feudal subperiod, from A. D. 1250 to A. D. 1450, - during which Western Europe seemed in danger of being resolved into a vast number of independent and quarrelsome principalities, may be designated, from that circumstance, as the Age of the Nobles. The political characteristics of the feudal sub-period having been already treated at some length in a previous chapter, we shall pass at once, without further comment, to that more recent sub-period which we have called the commercial.

The latter half of the fifteenth century gave birth to a number of remarkable events, many of them significant of, and others tending to produce, a great change in the political as well as social condition of Christendom. Among these events were the final expulsion of the English from France, and the great extension of the monarchical power in that country by the annexation to the French crown of the remaining great fiefs; the war of the Roses, so fatal to the old English nobility, and the great increase of the power of the English crown which followed the union of the rival houses of York and Lancaster; the union of the whole of Spain under Ferdinand and Isabella, and the vast extension which ensued of the monarchical power in that country; the marriage of Maximilian of Austria with the heiress of Burgundy, the union of the divided possessions of the house of Hapsburg in his person, the intermarriage of his son with the heiress of Castile, and the intimate alliance which presently followed between Spain and Austria, leading to a great increase of the Austrian influence. 
To these dynastic events may be added the abolition of private war in Germany, and the establishment of the Imperial Chamber for the settlement of the disputes of the sovereign princes, prelates, and cities; improvements in military science, and the substitution of mercenary armies of foot soldiers in place of the mounted feudal chivalry, by which the consequence and weight of the nobility were greatly diminishedvents tending also to the enhancement of monarchical ;ower; the introduction of the knowledge of the Greek 'anguage into Europe, and the new interest excited in - ae study of the ancient classical writers; the discovery and diffusion of the art of printing; and great advances, both in the art and the science of navigation, leading to the discovery of America, and of the passage to India by the Cape of Good Hope-events which tended to a great increase and diffusion of both knowledge and wealth among the burgher class, and a comparative depression of both nobles and clergy.

With the half century made illustrious by these occurrences, that which we call the commercial subperiod of modern history begins, divisible, like the other sub-periods, into two subdivisions of two centuries each, which may be respectively designated as the Age of the Kings and the Age of the Burgherssubdivisions which, with those of the feudal sub-period, serve to indicate the successive predominancy, during the eight centuries of the modern period, of the four great orders by whom, throughout that period, the political power of Christendom has been engrossed.

At the commencement of the sixteenth century, political power in Europe was shared between three sets of participators in a principal, and two other sets 
in an inferior degree. The greater portion of authority was now possessed by the kings, who had recently made great strides, and whose authority was supported by traditionary respect, by the idea of property in power, by the standing armies which they had begun to keep up, and by the revenue of their domains, to which the greater part of them had begun or were beginning to add the imposition of taxes at their pleasure, at least upon the tiers état, or body of citizens. Next were the nobles, whose power was upheld by traditionary respect, their great landed possessions, and their military spirit, skill, and courage. The clergy stood third, sustained by the still powerful though declining influence of mystical ideas, and the great amount of property in lands and tithes of which they had possessed themselves. A very inferior degree of influence was exercised by the lawyers, the nobles of the robe, resting upon their superior knowledge, and the favor and respect with which they were regarded as conservators of the peace and protectors of the rights of all; and still below the lawyers stood the citizens of the municipalities, who owed such share of political influence as they had to their concentration in towns and cities, to the riches in money and merchandise which they possessed, and to their superior knowledge, skill, and industry, employed in amassing wealth.

The great body of the people - the cultivators of the soil - had but recently in any part of Europe, and in many parts of it have as yet but partially, emerged from the condition of serfs. Of course, politically. speaking, they had no perceptible influence whatever. Even in the municipalities, the great mass 
of the artisans had been reduced almost to a similar political insignificance; the wealth, and along with it the political power, of those communities having concentrated in the hands of a few rich men, who constituted a sort of civic nobility, and who already began to purchase titles and privileges, to court intermarriages with, and to assume, as far as they might, the airs and pretensions of the old feudal nobles.

Luther's rebellion against the papal authority, the first successful resistance which, for centuries, Europe had seen to spiritual authority in spiritual matters, - by producing a schism among the clergy, tended greatly to diminish their political power, which, with some temporary fluctuations, has gone on diminishing from that day to this. This same schism operated greatly to strengthen the hands of the monarchs; for, while struggling hard to secure the kings on their side, the clergy, both Catholic and Protestant, bribed high, by the surrender to the monarchs of the nomination to the chief ecclesiastical benefices, and even of a large portion of the wealth of the church.

For many centuries preceding the Protestant reformation, the power of the kings and of the clergy had been antagonistical; but, in consequence of that event, a strict alliance began to be formed, alike in the Popish and the Protestant states, between the throne and the altar - an alliance necessary, perhaps, to the priests, but largely increasing the power of the kings, and tending to annihilate the political authority of the nobles and the citizens, reducing them to a common level with the emancipated serfs, and compressing the whole body of the subjects, so far as political rights were concerned, into one homogeneous, passive, unresisting mass. 
Some of the Protestants, in their anxiety to make the balance incline in their favor, seem to have been willing to push the doctrine of the divine right of kings to such an extent as to make it include the ultimate control of spiritual as well as of secular matters - the first commencement of that impious doctrine that there is no power nor law higher than that of the civil authority.

This coöperative union of the civil and spiritual power was carried furthest in the Spanish and Austrian dominions, particularly the former, vastly extended by the acquisition of Naples, Milan, and the Netherlands, and by the discovery of America, and the conquests achieved there by Cortez, Pizarro, and others. The Spaniards, it is to be observed, were never a commercial people. Their acquisitions in the new world were not the result of mercantile, nor even of colonizing enterprises, but the fruits of pure conquest. The theocratic governments which they overturned in America were easily replaced by a new Catholic theocracy dependent on the crown - the people, thoroughly broken to obedience by former rulers, submitting, almost without a struggle, to the change of masters.

In all those vast and wealthy dominions which, for two centuries, made the Spanish name at once the terror and the admiration of Europe, by the joint effort of king and priest, backed by the order of the Jesuits, and by the terrible tribunal of the Inquisition, the liberty of the press, the liberty of speech, almost the liberty of thought, were suppressed - a discipline fatal alike to noble and to citizen, under which the Spanish dominions sunk fast into a stupid lethargy, 
falling, as compared with the other states of Europe, at least a century behindhand in the progress of civilization.

Under the joint influence of Spain and the papal dominion, Italy, the birthplace and cradle of our modern civilization, science, and arts, its once famous republics reduced to insignificance or changed into tyrannies, its municipal spirit declining and almost extinguished, sunk, like Spain, into languor and decay.

In the rest of Europe, this partnership of power between the kings and the clergy was less successful. 'The foothold which Protestant ideas had obtained in France, Germany, and the northern nations, made it impossible for the Catholic priests, in spite of the powerful reaction and the efforts of the Jesuits during the latter part of the fifteenth century, to reëstablish their influence; while the mutual labors of the Catholic and Protestant clergy to damage and refute each other had a natural tendency to diminish the influence of both. It became necessary for the kings to choose between these two contending parties; and, by siding with the one, of course they made enemies of the other. In France, it cost the kingly power a whole century to break down the combination against it of the Protestant portion of the nobles and the municipalities; and the same cause, during the same period, occasioned repeated civil wars in Germany. It was the attempt, on the part of Philip II. of Spain, to carry out this Catholic reaction in the Netherlands, and to suppress the Calvinistic heresy there by fire, sword, and the Inquisition, which produced the revolt of those provinces - a revolt which seven of the 
poorer and least accessible of them succeeded, after a desperate struggle, in successfully maintaining.

The complicated administration of this emancipated Dutch republic presented a revival of the forms and spirit of the feudal ages. The control of the Dutch cities, and, through them, of the states, provincial and general, was in the hands of close corporations, a civic nobility which, though deeply imbued with and representing the municipal spirit, still kept the mass of the people in a degraded subjection. But so far as related to the general administration of affairs, this control was sometimes disputed and sometimes shared by the house of Orange, representing the monarchical power, backed by the rural nobles, and not unfrequently by the mass of the people. In fact, the Dutch Calvinistic clergy, jealous of the progress of Arminian opinions, threw themselves into the arms of the Prince of Orange; and, strengthened by this alliance, - so much like that of the Catholic clergy and monarchs, - they attempted to suppress the Arminian heresy by very much the same weapons which Philip II. had employed against themselves. But, with the growing wealth and intelligence of the Dutch cities, mystical influence rapidly diminished; and this republic first led the way in the modern system of toleration by allowing liberty of opinion to all Protestant sects. It was, indeed, hardly less by the freedom of publication which they first granted, than by the great wealth which they amassed by commerce, that the Dutch cáme to exercise so considerable an influence over European affairs.

Notwithstanding the efforts of Luther, and of the English clergy who favored the reformation, to secure 
monarchical support by pushing to most extravagant lengths the notion of the divine right of kings, yet the monarchs, by instinctive logic, were able to perceive that the fundamental Protestant doctrine of the right of private judgment, by which rebellion against the pope and the church was justified, might equally well be made to justify rebellion against themselves. Nor, indeed, did the nobles and the burgesses, with whom the Protestant doctrines principally found favor, at all respond to the slavish sentiments put forward by some of the Protestant clergy. Hence the efforts, on the part of the monarchs, coöperating with the church, having obtained from it those large concessions already alluded to, and being thus placed in a position to have less to dread from it than from the combined nobles and burgesses, to crush at once nobles, burgesses, and the Protestant heresy - efforts completely successful in Spain and Italy, and partially so in Germany and France. On the continent of Europe, it was only in the northern kingdoms of Sweden, Norway, and Denmark, in which, at the commencement of the reformation, the nobles had been all-powerful, (and the same was true of Scotland;) in the revolted Dutch provinces; in the more wealthy of the Swiss cantons, and of the German imperial cities; and in the dominions of a few princes of Northern and Eastern Germany, whose forefathers had become early champions of Protestantism against the efforts of the Emperor Charles V. to suppress it - standing thus, though, in most respects, sovereign princes themselves, yet, as feudataries of the empire, in the relation of nobles to a monarch;-it was only in these few spots of the continent (if we except the rights, speedily taken 
away, secured to the French Huguenots by the edict of Nantz) that Protestantism was left with a recognized existence by the famous peace of Munster, concluded in 1648, just at the termination of that period which we have denominated the age of the kings. Nor, indeed, could even this peace have been secured but for Richelieu's ambition to raise France, over the heads of Spain and Austria, to the leadership in Europe - an ambition to gratify which, while crushing the French Huguenots with one hand, he was led, as Francis I. had been before him, to aid with the other the Protestants of Holland and Germany. It seems, indeed, to have been only this want of union among the crowned heads, or those who acted for them, that saved Protestantism from total ruin.

The Catholic church, however, had not obtained this partial triumph except by the surrender of a large part of its wealth and independence, and by a suppression at least of its claims to supereminent authority; being now reduced to seek to exercise by indirection, and through the influence of father confessors over kings and their mistresses, that control which it had once boldly claimed in despite of kings, and in the face of the world. As to the Protestant clergy, though they labored hard to concentrate in their own hands all that domineering authority of which they had stripped their Catholic predecessors, they found themselves constantly thwarted, on the one side, by the educated and reflecting, who claimed more and more a right of private judgment, which verged fast upon freethinking, and the total denial, more or less explicit, of any such special divine commission and authority as the clergy claimed; and, on the other, by 
the same spirit developing itself among the ignorant and uncultivated, in claims of special personal illumination not less hostile to the pretensions of the established churches. Every where, indeed, throughout the Protestant states, - as we have already seen to have been the case in Holland, - the Protestants of the old school found themselves beset by a double-faced new school Protestantism, very much as, in the early days of the reformation, the old school Protestantism had beset Rome. The civil power, indeed, whose aid was loudly invoked by the Protestant clergy, was strong enough every where on the continent to suppress any new fanatical movement at progressive reformation, and even for a time to hold in check the freethinking tendency. But this last, with the peace, order, and increase of wealth and science, which followed the termination of the religious civil wars, continued to grow, silently but steadily.

During the whole of this period of two centuries, (1450-1650,) monarchical power, throughout the whole of Europe, - except towards the end of it, in England and Holland, - had been constantly on the advance. Strengthened by the adhesion of the clergy, and supported by standing armies, the monarchs had ceased any longer to assemble the States, Cortes, or Parliaments of their respective dominions; assuming to themselves the absolute right of levying taxes at their own pleasure - an assumption which struck a deathblow at what remained of the political power of the nobles and the municipalities. But, though very distasteful to the old feudal nobility, this increase of the monarchical power was not without its attendant benefits. The rapacity and violence natural 
to the nobles, which, especially during the religious civil wars, had risen to a fearful height, threatening a retrogression into barbarism, were restrained within certain legal limits. Life and property were rendered more secure. If the old municipal corporations and guilds found their particular local privileges and rights of self-government curtailed, they had long since ceased to be any thing but narrow civic aristocracies, the loss of whose privileges affected but a few individuals. On the other hand, the municipal spirit of the accumulation of wealth by industrious methods received a decided impulse, of which the fruits soon began to appear in a marked increase of riches, giving origin to a new civic aristocracy rising from the ranks of the burgesses, and attended by that increase of learning and refinement to which wealth and leisure are absolutely essential. And in this progress the feudal aristocracy largely shared; the increase of trade, population, and wealth, giving a new value to their lands, and, without any effort of their own, a corresponding increase to their income. Even the peasantry, but especially the laboring artisans of the towns, participated, to a certain degree, in this common progress - an important approach being made towards democratical equality by the compression of all the subjects into one homogeneous mass, with common interests and common feelings. So evident, indeed, was the superiority of this state of things over the old feudal violence and irregularities, that some able writers and good men, such as Grotius, became very favorably disposed towards absolute monarchy, as, on the whole, the best form of government. And so strong did this sentiment become, that, 
in 1661, the states of Denmark voluntarily acknowledged Frederic III. as their absolute king - a proceeding imitated, not long after, in Sweden, which, as well as Denmark, had suffered severely from the contentions of the nobles.

That England did not follow the career of the states of the continent; that the reformation was not checked there with a hand at least as strong as in France and Germany, if, indeed, Italy and Spain had not rather furnished the example; that the Parliament did not die out simultaneously with the similar continental assemblies, seems - on such slender threads does the fate of nations often hang - to have been largely owing to the self-willed caprices of a single man a man, however, who, from his position of monarch, constituted an order and a leading power in the state. It was nothing but the state quarrel of Henry VIII., about his divorce from Catharine of Aragon, with the pope, who did not dare to gratify him for fear of offending the Emperor Charles V., that carried Henry, contrary to the general royal impulse, to the Protestant side. He was willing enough, indeed, to break up the numerous monasteries and numneries for the sake of the rich plunder they afforded, and even to strip the secular clergy of a part of their vast possessions; but, otherwise, this "Defender of the Faith," who had written, in his younger days, against Luther, was much more of a usurper than of a reformer, preferring, so far as England was concerned, himself to step into the pope's shoes, and to dictate articles of faith to both clergy and laity alike. The clergy, both those inclined to the new doctrines and those disposed to adhere to the old ones, with a pliancy 
which shows how little hold the church had at that crisis, apart from its livings, upon the hearts even of its highest dignitaries, vied with each other in humoring the wishes of the king, who encountered only the opposition of one short and easily-suppressed insurrection in the northern counties.

After the brief minority of Edward VI., Mary, the daughter of the-divorced Catharine, succeeded to the throne, and yielding to the common royal impulse, - to which, indeed, her education and her natural sentiment for her mother's memory made her particularly accessible, - she did her best for the restoration of the ancient faith. Nor, indeed, would, perhaps, Elizabeth have been disinclined to the same course, had not her own title to the throne been involved in the sustentation of the ecclesiastical settlement introduced by her father. The position in which she was thus placed, as head of the Protestant opposition to the Catholic reaction, which soon began to assume a very formidable aspect, - a position which drew down upon her the excommunication of the pope, and the threatened invasion of Philip II., and exposed her constantly to a Catholic insurrection at home, - obliged her to court the favor of her subjects, by whom, especially the burgess part of them, she was enthusiastically supported; and also made it wholly impossible for her to discontinue or supersede the Parliament, with however little ceremony she might be accustomed occasionally to treat it.

But the semi-reformed church of England, while upheld by the queen against the Papists on the one hand, began to be assailed on the other, in an alarming manner, by the ultra reformers, known as "Puritans," 
against whom it was deemed necessary to enact persecuting laws no less than against the Catholics. This quarrel of the Puritans against the church of England was precisely the old quarrel of Luther and Calvin against the church of Rome. Under James I., - whom the gunpowder plot and the necessities of his position, as well as a taste for dogmatical theology much like that of Henry VIII., secured, though a very high churchman, on the Protestant side, - the church of England, growing somewhat bolder than it had been in Henry's and Elizabeth's time, began to claim to be the very old Catholic church, deriving its authority not from the parliamentary establishment, but by uninterrupted tradition from the apostles; if not that very Papal church which the more ardent reformers were accustomed to denounce as the scarlet woman of the Apocalypse, yet one to their eyes hardly less exceptionable. New pretensions like these gave, of course, a new zeal to the Puritan opposition, which embraced indiscriminately, at this early day, all the non-Catholic enemies of the church of England, both those who desired merely a further reformation, after the Presbyterian model of Geneva and Scotland, those who afterwards took the name of Independents, and even such few Freethinkers as yet there were in England.

Simultaneously with this growth of Puritan opposition, and indeed in a considerable measure productive of it, had been the great increase of London in population and wealth; that city, much to the terror of the ruling powers, who desired anxiously to limit its increase, having risen, during a century and a half of internal peace and freedom from taxation, 
to be one of the chief commercial marts of Europe; other commercial and manufacturing towns, indeed the whole kingdom, having shared also in this growing prosperity. Hence an increasing spirit and courage, on the part of the Commons, and the resistance which Charles I. encountered when, unsustained by a standing army, he attempted to do, what was done by almost all the kings his contemporaries, and what had occasionally been done by the more vigorous of his predecessors on the English throne, viz., to levy money on his subjects by his own mere authority.

In the civil war that ensued, the clergy, the peers, and the old feudal landed gentry sided with the king against the Puritans, the citizens, and the small proprietors, who had invested in land the gains of trade, emphatically a burgher party - for as to the great mass of the cultivators of the soil, so far as opinion went, they took no side whatever, merely following as their landlords led.

The king and his party were beaten, the war being sustained against them chiefly by the efforts of the city of London. Cromwell, by means of his superior sagacity, activity, courage, temper, and warlike and political skill, largely aided by his mystical influence over the Independents, - for he was saint and preacher as well as statesman and soldier, - secured the command of the parliamentary troops, and, by the aid of their swords, raised himself to supreme power. The rise of this brewer over the dead body of the executed king, and the heads of all the old nobility, to be "Lord Protector of the liberties of England," marks decisively the commencement of 
that which we have designated as the Age of the Burghers.

After the death of Cromwell, the influence of traditionary respect so far revived as to reëstablish the monarchy, and the nobles and the bishops along with it. The Independents were suppressed with unrelenting severity, and the freedom of the press and the liberty of worship, which Cromwell had tolerated, were no longer allowed. Charles II. and his brother James after him, supported by the church and the feudal gentry, were suffered to go great lengths in the reëstablishment of monarchical authority. But, when James undertook to claim tolerance and equality for the Catholic faith, which he had embraced, - a toleration doubtless intended to pave the way for Catholic restoration, - that very church of England, which, as against Roundheads and Puritans, had preached passive obedience for thirty years, abandoned him, allowing the Prince of Orange to take possession of the throne. The partisans of this new parliamentary king, as an offset to the hereditary claims of James II., sought aid from the late depressed dissenters by establishing the toleration of all Protestant sects, hitherto unknown, except in Holland, and in England during Cromwell's protectorate, but which now became the public law of Britain; thus, by further dividing it, still further weakening the mystical political power.

From the era of the restoration it had begun to be seen that the control of English affairs rested with those who could control a majority of the House of Commons - a thing made evident enough, not merely by the parliamentary title conferred on William of 
ADDITIONAI, Ill,USTRATIONS FROM HISTORY, 185

Orange, but by the subsequent repudiation of the entire Stuart family, and the substitution of that of Hanover instead. As this preponderance of the House of Commons - which took care to vote neither money nor soldiers, except from year to year, thus keeping the executive at their mercy - became more and more apparent, no means were left untried to secure votes in that body. The elections in the counties - in which freeholders only voted - had always been determined, to a greater or less extent, by a few great landholders, who now made the most strenuous efforts to increase their influence in this respect. They demanded the votes of their tenants as part of the consideration of occupancy, just as in feudal times they had demanded their military services; and in this way the sons or other relations of many peers sat in the House of Commons, while the family was at the same time represented in the House of Lords. Nor did this sort of influence by any means stop here. Many of the old boroughs, which had obtained by usage the right of sending members to Parliament, had always been inconsiderable; many others had fallen to decay. The lands and houses of these boroughs were bought up, and a controlling influence over them was thus established by a few rich men; so that, in process of time, it came to pass that a majority of the House of Commons was nominated by about a hundred and fifty peers, or very rich commoners preparing to become peers - a body aptly enough designated as the "oligarchy of borough-mongers." That moneyed influence, indeed, which had turned the middle age municipalities into close corporations, was now at 
full work in the realm of England. Even of the nominally independent seats, a great many were carried by the grossest bribery; the great political right of voting for members of the House of Commons became a regular article of merchandise; so that wealth tended rapidly to become the sole source of power, to which hereditary respect, mystical influence, even sagacity, knowledge, courage, eloquence, and virtue, were but mere secondary supporters. And, as might be expected under such circumstances, to facilitate the accumulation of wealth by a few, at the expense as well of the mass of the people as of foreign nations, became almost the sole object of the policy of government, of which "trade" was the great idol, for the promotion of which both diplomacy and war were alike resorted to. The little knot of immensely rich men who thus gradually engrossed the control of the British government, - a vast power which they wielded, or strove to wield, so as still further to increase their own overgrown wealth, - had they been able to agree among themselves, might, and probably would, presently have established a despotism as narrow, as suspicious, as dark as that of the Venetian aristocracy, which had mưch of a similar origin. But, fortunately, in common with the voters, whose political influence they sought to purchase up, the "borough-mongers" were themselves divided into two factions, entertaining a traditionary hatred of each other; the one consisting of the Whigs, the descendants of the Roundheads, who had brought Charles I. to the block, and who had, to a great extent, - so far at least as the monarch and the church of England were concerned, - thrown 
off the influence of hereditary respect and mystical ideas; the others the descendants of the Cavaliers, who still felt to a considerable degree those influences, evinced in a blind attachment to the church (chiefly exhibited in the hatred of all dissenters from it) and a sentiment of loyalty towards the exiled Stuart family, presently transferred (length of possession, even in their eyes, growing into right) to the young king, George III.

The "borough-mongers" might perhaps have reconciled these differences, had they been the only parties concerned; but, fortunately, their power was a good deal limited by the continued existence, in the House of Commons, of a minority of independent members - the representatives of the great towns, - such of them as were of antiquity enough to have members at all, - and of such of the counties as had not yet fallen under the exclusive control of some great family. To enable either of the factions into which the "borough-mongers" were divided to go on with the government, it was necessary to secure the aid and support of a considerable portion of these independent members, who, though they were often privately for sale, were yet obliged, as the price of their seats, to affect publicly, whether they felt it or not, a certåin sympathy with the dominant ideas of their constituents - a necessity which extended also to those borough-mongering parliamentary leaders who courted their votes.

Meanwhile, the faction out of power, whichsoever it might be, - and in the interval from the accession of the house of Hanover to that of George III., (17141760, ) the Tories were in this predicament, - felt the 
necessity of vindicating for themselves - and, whether willingly or not, they did it, at the same time, for the mass of the people - freedom from arbitrary arrests and imprisonment, the trial by jury in criminal cases, the liberty of speech, the liberty of the press, of petition, and of public assemblies, and, within certain limits, the liberty of worship; and it is these inestimable rights and privileges which make up that which is so proudly denominated English liberty - a liberty not of self-government, but, what comes next to it, of remonstrance and complaint against the acts of the government.

The Tories, it is to be observed, as they consisted almost entirely of landholders, formed what was called the landed interest. The Whigs, though there were many great landholders among them, assumed the patronage of, kept up an intimate connection with, and were strongly supported by the merchants, manufacturers, and bankers, who constituted what was called the moneyed interest-from which class, indeed, a large part of the Whig nobility and gentry were, at least on one side of their pedigree, descended, however, on the other, they might trace themselves back to some old feudal noble.

While in Britain, — and the same thing occurred in Holland, - during the first century of our burgher age, $(1650-1750$,$) the burgher spirit of the accumula-$ tion of wealth by trade and manufactures continued to advance, elevating accumulated wealth into the great leading element of power, a like, though far inferior, development of the same spirit took place on the continent. But of this the as yet only apparent political effect was, still further to increase the power 
of the kings by putting, through the unrestricted right of taxation which they had assumed, new pecuniary resources into their hands; to which they even added the practice of funded debts first introduced by Holland and England - a practice, however, which tended to throw them directly into the power of the burgher moneyed class.

Meanwhile, that influence of mystical ideas and of traditional respect on which rested the social and political position of the nobles and the clergy continued from day to day to decline. As it had happened at Athens, and afterwards at Florence and in the other Italian republics, the accumulation of wealth, not by plunder, but by industry, gave rise to intelligent and thoughtful leisure. The spirit was again born of independent inquiry, scorning to transmit a merely traditionary science. Bacon and Hobbes in England, and Galileo and Des Cartes on the continent, became the fathers of modern freethinking, followed up by the learned, witty, and ingenious Bayle, who, however, instead of attempting, like Hobbes and Des Cartes, to establish any theory of his own, contented himself with that critical examination into the foundation of existing opinions, and that exposure of the logical inconsistency of those opinions, which is a necessary precedent to true science.*

The English sect of Freethinkers divided into two schools, - the one semi-mystic, and the other philosophic, - deriving their origin, respectively, from Lord Herbert of Cherbury, and from Hobbes. Some of

* "If a man will begin in certainties, he shall end in doubts; but if he will be content to begin with doubts, he shall end in certainties." BAcos, Advancement of Learning, Book I. 
its members, like Locke and Middleton, though they went the whole length in premises, were yet so much under the influence of prevailing ideas, or prudential considerations, as to go, at least on certain topics, but little way in conclusions. This was the sect distinguished as Latitudinarians. They fully admitted the supernatural origin of the Christian church, but, at the same time, strenuously resisted all present mystical pretensions to authority; reducing the determination of the character of Christianity to a purely historical and documentary question, and the doctrine itself to a mere code of morals. In their steps followed the whole school of Presbyterian and Calvinistic divines, (as well the low church, or Presbyterian section of the church of England, as most of the German Lutherans and Swiss and Dutch Calvinists, ) the whole body of whom, pastors and people, including the body of the burgher class, throughout Europe, verged fast towards rationalism; being separated from the more advanced Freethinkers only by an uncertain and almost impercepible partition.

Of this more advanced section, some, like Bolingbroke, following out the ideas of Herbert, proposed, as a substitute for Christianity, a system of their own, which acquired the name of Deism; the adherents of which, it may be observed, - and Voltaire, Robespierre, and Thomas Paine may scrve as instances, - in point of vehement bigotry and bitter intolerance, whether of those who believed more or those who believed less than themselves, did not fall a whit behind any of the religious sects. Others, like Hume, folfowing up the doctrines of Hobbes and Locke, ventured, obscurely indeed, and only by 
ADDITIONAL ILLUSTRATIONS FROM HISTORY. 191

implication, to call in question the entire mystical hypothesis.

This freethinking disposition - which, beginning with the denial of witchcraft, and of the power of the devil, seemed likely to end, as Baxter and Cotton Mather had foretold, in the denial of the providence, and, what seemed to them almost, if not quite, essential to the being, the personality, of God - naturally aroused a strong spirit of resistance on the part of all the orthodox divines, who called loudly on the civil power to interfere for the support of religion, on the ground, among others, that Christianity was part of the law of the land-in other words, one of those vested rights, at least as to the power and property possessed under it, which the civil law recognized, and would sustain. Even a large part of the Latitudinarian divines joined also in this cry, assuming the position that religious belief is the only solid support of morals and government - the only thing that can keep the depressed and impoverished masses from rising in their fury, and, without regard to property or vested rights, completely overturning the existing system of things. To this appeal the civil powers responded, though not with any great energy, as being themselves deeply infected with those very heresies which they were called upon to suppress. Yet a certain disguise and reserve were still necessary in the expression of opinions; imprisonment, fines, the pillory, and outlawry being substituted, in the case of less cautious offenders, in place of the gibbet and the stake of two hundred years before; the burning of heretics being now every where discontinued, except occasionally in the Spanish dominions. 
An interference of the civil power, so feeble and inefficient, served but as water to the fire, which burned all the brighter in consequence. The only really formidable opposition to the growth and spread of freethinking came from quite another quarter. In the world of ideas, as in the physical world, every powerful impulse forward inevitably produces a corresponding backward eddy, which finally becomes, or may become, even a powerful current of reaction. It had been so in the case of the Protestant reformation, which encountered, in the reactionary movement of Loyola and his Jesuits, an opposition even more formidable than that of the monarchical power. A similar reaction against the Freethinkers commenced in England with the preaching of Wesley and Whitefield, who revived, in a somewhat modified shape, the decaying notions of the Puritans and Independents; but with this important difference, that, while Calvinism and Puritanism had been progressive, levelling, and destructive, Methodism was retrogressive, constructive, and reëdifying. It is not, however, in the nature of any vibration, where the impulse is merely reactionary, quite to return to the point whence the original movement commenced; and though, in reference to the Freethinkers, the Methodist revival was undoubtedly retrograde, in relation to the views held by the early reformers, and by the great mass of the Puritans, and embodied into so many national and sectarian creeds, it must be regarded as decidedly progressive.

According to the view of human nature originally promulgated by Saint Augustine at the commencement of the fifth century, revived by Luther, ex- 
pounded by Calvin, and made the basis of the Protestant creeds, mankind consists of two orders, separated by the widest and most impassable barriers. The great body of the human race, destitute of any free will, and capable only of evil, are ordained by the divine decrees "to the praise," as the Savoy confession expressed it, "of God's glorious justice" to eternal wrath and dishonor, as well on account of their corrupted nature inherited from Adam as of the particular and individual sins to which that corrupted nature impels them. From among these miserable heirs of sin and wretchedness a few, however, have been selected, not from any foresight of faith and good works on their part, but out of God's pure favor, and "to the praise of his glorious grace;" and, having thus been predestinated, before the foundation of the world, to everlasting glory, these elected few, at some time in the course of their mortal career, are certain to be endowed with free-will and a disposition and capacity for goodness; after which it becomes impossible for them, much as they may backslide, utterly to fall away.

However legitimate an inference this doctrine may appear to be from the mystical hypothesis; however useful it might have been towards battering down the pretensions to traditionary authority set up by the Papal and English churches, - yet not only did it shock the growing force of the sentiment of benevolence, but, in its mockery of all human effort, and in making God himself the author and ordainer of sin, (however it might be attempted to evade that consequence,) it placed formidable obstacles in the way of 
those who would build up a new church to be based upon faith, repentance, and good works.

Hence the revivalists either rejected this view of human nature with indignation, adopting without reserve, like Wesley, the semi-mystic theory of the Arminians and the Jesuits, thus striking a serious blow at the mystic hypothesis; or, in their ingenious struggles, as in the case of Edwards, to maintain the purely mystical view, they did but prepare the way for still wider departures from it. Whatever the merits of this theory of the Calvinists in vindicating the freedom of the individual, at least of a limited number of elected individuals, against the centralizing and monarchical claims set up by the Papal, the English, and even the Presbyterian churches, yet it is hardly possible to conceive of any view of human nature more essentially aristocratic and narrow, more thoroughly in the spirit of caste. It is, indeed, this very character of it that so warmly recommends it to a certain kind of tempers, and that made it so suitable to the times in which it flourished. The Methodistical view, on the other hand, by vindicating free will and the chance of salvation as appertaining to the whole human family, and still more by its doctrine of falling from grace as a danger to which even the best are exposed, went a great way to break down that impassable barrier which Calvinism had erected between its two supposed orders of the elect and the reprobated; and, in comparison with that stern and haughty creed, it might well claim a democratical character. And yet, in establishing for his special adherents a system of church government, Wesley deliberately passed by all those republican, and, in the case 
of the Independents and Baptists, democratic forms, which the ultra supporters of the Calvinistic view had introduced; and, by vesting the whole authority in conferences composed entirely of the clergy, in the ordination and displacement of whom, and their appointment to particular charges, the clergy solely participated, he approached very nearly to the secular principle of close, self-perpetuating corporations - a form of government which might, perhaps, have existed in the early Christian church prior to the establishment of the patriarchal and papal authority, but which appears, nevertheless, so far as the obscurity of the question allows one to judge, to have been a deviation from primitive usage, and a usurpation upon the rights of the body of the Christian people.

The first converts, in this revival of old ideas, - for such, at its commencement, Methodism appeared exclusively to be, - were obtained, as commonly happens in such cases, from among the least cultivated portions of society. But, ultimately, spreading among the higher ranks, it made a serious impression on the church of England, superseding the latitudinarianism of the Low Church party, which, at length, took to itself the new name of Evangelical. It also gained possession of the Presbyterian church of Scotland; and, besides the new Methodist church founded by Wesley, who had a great talent for ruling, it greatly increased the numbers and social weight of the Baptist and Congregational dissenters. Even the modern party of the Puseyites, so far as they differ from the old High Churchmen, owe their origin to this same Methodistical impulse.

Strong indications simultaneously appeared in Ger- 
many of a similar reaction. Wesley and Whitefield - had their counterparts in Count Zinzendorf and others. But, as toleration of religious worship other than that established by the state formed no part of the continental system, the German Pietists were cut off from the great resource of field preaching, and could only partially propagate their opinions through such few regular pulpits as they could gain access to, and by the aid of the press, which, however, was subjected to great shackles.

In France, there seems to have been 110 reaction at all; while, under the auspices of Voltaire, Rousseau, and the encyclopædists, - writers in whom eloquence, sagacity, and the knowledge of reflection, as apart from mere pedantry and book learning, formed a union unknown before since the days of elassical antiquity, - the deistical system of freethinking obtained, among all the reading class, a very decided preponderance. These new ideas spread even into Spain; and their first political fruits were presently seen in the expulsion of the Jesuits from France, Spain, and Portugal, speedily followed by the abolition of that order. But it was not solely, nor, at least on the continent, prineipally, against mystical ideas, and the political pretensions of the clergy, that the batteries of the Freethinkers were directed.

The introduction into England, by, the Normans, of the doctrine of primogeniture, in a stricter sense than was usual on the continent, - the entire landed property, which, in those times, was substantially all the property, descending to the eldest son, - had been attended there with one result, hardly, at first thought, to have been expected from it. The old 
rights and special privileges of the feudal nobles, instead of being transmitted by inheritance, as on the continent, to all their descendants, became strictly limited to a hundred or two peers, who composed the House of Lords, all the other branches of those families, - even the eldest sons of the highest rank of noblemen, so long as their fathers were alive, - however they might bear titles through courtesy, being, in law, commoners, and nothing more. Thus the doctrine of primogeniture had greatly contributed to do away, except as to a very few families, the distinction of rank as between the old feudal nobility and the new civic gentry of burgher origin. It is true that the cadets of noble families, as well as the knights and squires who represented the old feudal gentry, would, and did, take some airs to themselves on the ground of a pretended superiority of blood. But, in political rights, they enjoyed no preëminence; and already, in Britain, the son of a tinker, with money or official station, might claim to be, and actually was, socially and politically, a much more important personage than the son of an earl without them. On the continent it was not so. The distinction of caste was there in full force. It was only nobles who could hold commissions in the army, or could fill many chief official stations; even all the benefices of the church, worth having, were chiefly engrossed by them. They disdained all industrious employments as beneath the dignity of their blood; and their constantly-increasing numbers had to be provided for by quartering them, in some way, on the industrious classes.

These distinctions were most bitterly felt by the 
burgher class, which, in wealth, intelligence, and every natural element of power, had now grown to be the superiors of this caste of nobles; and the freethinking literati, emanating, as they chiefly did, from the burgher class, and writing mainly in its interest, directed the whole weight of their satire and their argument, their wit and their learning, against distinctions, which rested now for their sole support upon mere custom and genealogical tradition.

As an offset to the divine right of kings, - the favorite theory of the clergy, - to the right of blood and descent alleged by the nobles, to the right of prescription, or of property in power, urged by the lawyers, the continental writers of the new school, no longer Freethinkers merely, but now become dogmatists, set up the doctrine of "the imprescriptable rights of man;" and they also started, as supplementary to that doctrine, the metaphysical theory of the natural equality of men, - all existing inequalities being ascribed to accidental and temporary deviations from the true law of nature, - a doctrine fatal enough, no doubt, to the pretensions of the nobles, but giving also a logical basis to all those anarchical consequences already pointed out./

Yet, omitting to press this proclamation of equality to its strict logical conclusions, and viewing it such as it was, in fact, merely as a protest against distinctions, of which the original and natural basis had disappeared, there was something in it to which every noble and self-confident soul responded; and this new doctrine found many advocates, even in the very ranks of the nobles themselves - just as there were also among the continental clergy many who 
openly laughed at the pretensions on which the clerical power was based.

Even kings - though their pretensions, too, were assailed in common with those of the clergy and the nobles - were carried away by this new burgher philosophy, which, in striking at the last remaining feudal privileges, seemed, indeed, likely to leave the monarchical power without any restraint. It was partly, perhaps, this consideration which induced Frederic the Great of Prussia to become a talking disciple of this school. Joseph II. of Austria - more enthusiastic, if not more sincere - undertook to carry its doctrine into practice.

In addition to this false theory of absolute natural equality, there were other not less grievous defects in the new philosophy - smacking, indeed, of its burgher origin, smelling a little too strong of the shop. As the men of the world, and the politicians of this school, had but the one notion of money as the sole basis of preëminence, so its metaphysicians were induced to reject all ideas which they could not trace distinctly to some external sensible prototype. The burgher economists and politicians believed in nothing but gold and silver - the burgher metaphysicians in nothing that could not be seen, heard, handled, smelt, or tasted.)

Among other causes which promoted the accumulation of wealth in Europe, and the consequent progress and development of the burgher spirit, was the increasing commercial importance of the European ultramarine possessions, especially those of the new world.

The Spanish ultramarine possessions, as has been already remarked, were the fruits of conquest rather than of colonization; and the same thing was, in 
a great measure, true of those of Portugal also. Such colonies as wcre actually founded by these two nations were very closely modelled after the state of things in the mother country. Negro slaves, imported from Africa, or Indians reduced to a state of servitude, furnished a laboring population even more oppressed and degraded than the serfs of the feudal age. The Catholic church was transplanted full blown to the colonies, and was endowed with ample possessions. The native Spaniards and Portuguese, who resorted to those countries in pursuit of fortune, even those of the meanest origin, stood, towards the native-born inhabitants, not even excluding those of European descent, in the relation of a superior caste, or privileged order of nobles, constantly renewed by fresh migration, and possessing a monopoly of official employment; while the courts of law, and the viceroyal administrations, faithfully enough reflected the corresponding departments at home.

To the French colonies, which were, indeed, but feeble, similar observations will apply. The Dutch colonies were founded and governed after a home model, of which a close burgher aristocracy formed the most conspicuous feature, not, however, without the intermixture of other feudal ingredients.

Of the English colonies, particularly of those which now constitute the United States of America, the case was very different. If we except a limited number of indented servants, who soon, however, became freemen and freeholders, on a par with the rest, the settlers by whom these colonies were founded were almost exclusively from the burgher class; and the 
governments of all of them were constructed essentially upon municipal ideas - ideas not of the degenerate close corporation sort, but such as had prevailed in the feudal age municipalities in the days of their vigor and freedom. All of these English colonies had Houses of Assembly, in the election of whose members all the freemen voted, and without whose consent no laws could be made nor taxes levied. They enjoyed, too, the inestimable political privilege of trial by jury - and in the greater perfection as the judges were generally not lawyers, and therefore not in a position to undertake to dictate either as to law or facts. There was no order of nobility, and the kingly power was very faintly represented by the royal or proprietary governors and councillors. Two of the New England colonies had even the right to elect their own chief magistrates. It is true that, in the older colonies, - Rhode Island excepted, — an established church made a part of the political ma chinery; and that, in Massachusetts and Connecticut, it was even attempted to establish a democratic theocracy - none but " church members" being, by the earlier constitutions of those colonies, ${ }^{*}$ entitled to be freemen. But this project, after fifty years' trial, had to be abandoned. A small pecuniary qualification was substituted; and the colonies of New England, as

* Though this is stated of Connecticut gencrally, it ought in strictness to be limited to the old New Haven colony. The Hartford colony (and the same was true of the Plymouth colony, afterwards absorbed into Massachusetts) did not profess, in terms, to limit citizenship to church members. Their practice, however, was not materially different from that of their sister colonies, the four forming together the New England Confederated Union, of which theocratical interests were a leading object. 
well as those of Virginia and Maryland, were obliged, by repeated orders from the mother country, to adopt the policy of the toleration of all Protestant sects - a principle upon which some of the younger colonies, such as the Jerseys, the Carolinas, and Pennsylvania, were expressly founded; Rhode Island having, at a still earlier day, set the example, which Penn imitated, of leaving public religious worship and training entirely to such voluntary organizations as might choose to undertake it.

But, along with this reproduction in America of new and vigorous shoots from the old municipal ideas of Europe, a noisome weed sprung up, - one which still threatens failure to the whole experiment, - the unfortunate introduction of the system of chattel slavery, domestic and predial, and along with it of a spirit of caste of the most inveterate sort.

The British Parliament, having centred in itself the whole political power of that country, naturally claimed a supremacy over the colonies similar to that originally claimed by the kings of England, and actually possessed by those of France and Spain, over their ultramarine possessions. And, so long as this supremacy of Parliament was confined within those limits to which the early weakness of the colonies had obliged them to submit, - that is, to the regulation of trade for the special and exclusive benefit of the mother country, and that, too, upon a very narrow system, - whatever heartburnings it might occasion, and however it might be evaded, it was not openly resisted, nor even verbally disputed. But when an attempt was made to extend it beyond those limits, by assuming a right to impose taxes on 
the colonists by act of Parliament, an opposition was made similar to that encountered in England by Charles I., when he attempted to levy taxes without the consent of Parliament, and precisely on the same ground too, that it was contrary to the rights of Englishmen - the fullest participation in which was claimed by the colonists - to be compelled to pay taxes in the levy of which they had no voice.

In place of the aid which the English supporters of municipal ideas had derived, in their contest with Charles I., from the religious enthusiasm of the Puritans and Independents, the colonial opponents of parliamentary despotism had the support of the new philosophy; and in the progress of the dispute as to the power of Parliament, the new ideas respecting the natural equality of man, which Rousseau had so eloquently expounded, gained a great currency in the British American colonies, and, simultaneously with the declaration of American independence, became a part of the national political creed.

The American revolution extinguished, in the late British colonies, the royal authority, and all monarchical ideas along with it; and, although the commencement of the mystical reaction had been felt in America, not less than in Great Britain, that revolution also deprived the clergy in the southern colonies of all political weight, and even somewhat weakened the clerical influence in New England. But, by reason of the great importance attached to those politicolegal disputes by which the war of the revolution had been preceded; by reason of the many doubtful constitutional questions to which the new forms of government gave rise; and especially by reason 
of the enormous fluctuations of property, and the complicated indebtedness oceasioned by the war, the paper money, and the funding system, - the lawyers were multiplied and enriched; and gradually obtaining a monopoly of the seats on the judicial bench, they began to form a separate order, a sort of noblesse of the robe, not without a distinct and decided social and political influence. Apart from the special ingredients of slavery and the influence of the lawyers, as the new governments which sprung up in America were modelled - the general government as well as the state governments - almost entirely after the colonial system, so werc they almost exclusively municipal in their character. They have, indeed, given a thus far most successful instance of the application to a large extent of country of that form of government originally established in the free towns of Europe, which, so far from being fit for small communities only, as Montesquieu and many others had imagined, has been found to operate with far less friction on a large scale than a small one.

Hume, indeed, had the sagacity to perceive that the republican form of government might easily be applied to almost any extent of country - an opinion advanced in his Essay on the Idea of a Perfect Commonwealth. But, among many less acute European writers, the opinion of Montesquieu still remains a favorite one, that republican institutions are only adapted to poor and thinly-inhabited countries, and that, as the United States of America become rich and populous, democracy will die out, and give place to monarchy and aristocracy. Upon this point it is only necessary here to observe, that 
the States of Massachusetts, Connecticut, and Rhode Island, the portion of the Union the wealthiest and the most thickly populated, - points in which few districts of Europe stand very greatly before them, - are, at the same time, the most thoroughly democratic, having grown so just in proportion as wealth has increased and population multiplied a phenomenon not peculiar to them, but one of which the operation may be traced in all the free states of the American Union.

To this flattering prospect there is, however, one painful drawback. The unfortunate introduction of negro slavery, at first a mere excrescence upon the original plan, but which has grown, in several of the southern states, both new and old ones, to be the most marked feature and predominating influence in their social system, has introduced into that portion of the American Union, and indeed into the administration of the national government, a strange and most incongruous mixture of the republican system of equal rights, backed by the metaphysical theory of the natural equality of man, with the spirit of caste and an hereditary aristocracy of birth and race-a state of society engendering all that spirit of contempt for mechanical, and especially for agricultural, industry; all that spirit of plunder and domineering insolence and cruelty which distinguished the republics of ancient times, but without their taste, eloquence, and artistical and warlike renown; and at the same time all the huckstering trickery, sharpness, and meanness of the modern municipal system, without its equality, industry, wealth, and comfort. Nor can any man yet tell what, as to the entire American 
Union, the result is to be of this most discordant and incongruous mixture.

The successful accomplishment of the American revolution, - which had been watched from Europe with the most lively interest, - by giving the example of the establishment of a purely municipal system on a large scale, tended to hasten that great and concluding catastrophe of our commercial era, the French revolution - a revolution still in progress under our very eyes.

That revolution was made entirely by the burgher class, and their converts from among the nobility and clergy. The great body of the cultivators of the soil, oppressed by taxes and feudal executions, and sunk in ignorance and superstition, took comparatively little part in the movement, except to avail themselves of the opportunity afforded by it to shake off their feudal burdens, and to be acknowledged as men and citizens. These great boons they obtained in the very first years of the revolution, and with these they remained content. As to the particular form of the government, whether republican or otherwise, or who should exercise it, that was a matter about which they concerned themselves very little. These mere questions of administration they left to be settled by Paris and the armies.

The freethinking philosophers, who had been the chief authors of the revolution, and who were the principal leaders in it, were disposed to make very thorough work. They did not, like what are called "practical men," incline to patch up and remodel an old system, in their view radically false. The first thing necessary, in their opinion, was to pull down the 
whole of the old fabric; and that which the National Assembly omitted to do in this respect was fully carried out by the National Convention. The Girondin party wished, indeed, to preserve the distinction of provinces, and, by a return in some respects to the ideas of the feudal age, to decentralize the government, and to disperse and localize authority - great boons for liberty, could that system have been adopted. But the danger from abroad in which France stood at that moment - the crowned heads of Europe having taken the alarm and united to put down the new republic - enabled the Jacobins, the thorough-going and uncompromising theorists, with Robespierre at their head, to carry the day; and, by means of their affiliated clubs, to establish that "reign of terror," the reign of the republic, "one and indivisible," so execrated in history, and so fatal to many of the prominent actors on the early stage of the revolution a bloody and fearful dictatorship, which, if it saved France, for the time, from being subjected by foreign armies, has also deferred, from that day to this, the establishment there of an internal administration making even a distant approach towards what is entitled to be called a free government.

The very sweeping redistribution of property by the sale for assignats of the forfeited lands of the crown, the elergy, and emigrant nobles, and the new distribution of military honors by laying open the highest commands to soldiers in the ranks, created, indeed, a body embracing by far the larger part of what there was in France of activity, courage, intelligence, spirit, and enterprise, bound by the strongest interests to support and uphold the revolution at all hazards. But 
out of France, the reaction occasioned by the reign of terror was almost as complete as it was sudden. It was in vain to say that the introducers of the system of terror were not any of the philosophers, nor of their proselytes - not the "virtuous and incorruptible" Robespierre, who had formerly refused the place of judge rather than be implicated in the shedding of human blood, but the half-insane Marat, and the luxurious, corrupt, and unscrupulous Danton, who thought of nothing except power and riches for himself, however it has suited some "hero worshippers" to make him a demigod, while, at the same time, they spit venom at the "sea-green" Robespierre. It is in vain to say, as it has been since said, that the system of terror was, after all, no new invention, only the usual and established method, carried out a little more vigorously than common, by which authority, ever since the world began, has made itself respected, and that the atrocities so much blazoned, and made such a scarecrow of, will be found, upon any fair comparison, to fall short of those committed within the last sixty years by each and every of the leading "legitimate" governments of Europe - in Ireland, India, China, Italy, Poland, Algiers, Circassia, and Hungary. It is in vain to suggest that these atrocities were, in fact, acts of war, not committed in the ordinary course of administration, but by reason of the alarm which threatened attack inspired, and as measures of selfdefence against the coöperation, for the reëstablishment of the old despotism, of internal traitors with external enemies. It is in vain to add that all revolutionary governments, - even those whose object it is to establish the liberties of the people, - so long as 
their existence is threatened by hostilities external or internal, are obliged to convert themselves into dictatorships, and to venture, for the time being, on acts of authority vastly more arbitrary than those which - had provoked the revolution: compare, for instance, the British tax on tea with Washington's forcible seizure, under authority of Congress, of provisions for his army, paying for them in congressional paper money not worth thirty cents on the dollar, and the denunciations levelled by the Congress and its agents against those who refused to take this depreciated and depreciating paper at its par value. All these things might be; yet they only proved, at the most, that the French revolution was not, after all, so very different from other revolutions, nor the leaders in it so much worse than other politicians and fierce contestants for power. But what had become of the splendid dream of a new golden age of natural equality and imprescriptible rights, to be ushered in under the auspices of enthusiastic philosophers, whose heads the remorseless guillotine had already chopped off? Strange era of freedom of opinion that, in which one set of victims was sent to the scaffold because they were charged with being atheists, and another because they adhered to the faith of their fathers! Had not the pretended capacity of men to govern themselves been experimentally proved, in the face of the world, to be nothing but a mad and bloody delusion? In overturning the influence of mystical ideas and hereditary respect, what, except to unchain the tiger, had been done by the philosophers lately so admired, but whose very names began now to be pronounced with execration? It was true, then, after all, that only by 
the authority of kings, priests, and nobles, could men be kept in order. Did not the experiment of the French revolution conclusively show that there was no other basis on which property and morals could stand, except those very mystical ideas so much scouted by the Freethinkers?

Nor were these reactionary views at all confined to the monarchs, nobles, and clergy. They were shared also, to a very great extent, by the burgher class, the necks of whose leading representatives in France had felt the edge of the Jacobin guillotine scarcely in a less degree than the clergy and the nobles. Especially was this the case in England, where mystical ideas, partly in consequence of the Methodist reaction, had preserved a much stronger hold upon the burgher class than any where else in Europe ; and where, in consequence of the strong conservative reaction which now commenced, the "oligarchy of borough-mongers," contrary to every indication, a few years before, was able to prolong its existence for forty years, and partially so even to the present moment.

The elder Pitt had been the first man to shake the power of the "borough-mongers." His eloquence and energy, and the popular favor by which he was backed, had enabled him, at a crisis when unsuccessful war made incapacity apparent, to raise himself to the head of the ministry in spite of them. The great advance in productive industry which took place in England, commencing with the latter half of the eighteenth century, and the consequent increasing wealth and political weight of the burgher class; the complete establishment of the liberty of the press, and the multiplication of periodicals in which polit- 
ical questions were discussed; the publication of the parliamentary debates - itself, in the check which it placed upon the "borough-mongers," equivalent almost to a revolution, - all these causes had combined to give to the burgher class a new interest in politics. No longer kept quiet by the mere faint shadow of parliamentary representation, (mistaking the contests of the little factions of Whigs and Tories on the mere point of who should be in and who should be out for the contest of popular liberty against monarchical power,) they had begun, for some years previous to the French revolution, to open their eyes, and to demand something more than a mere show of participation in the government. And for this there was the more occasion, since the Whigs and Tories, who had for some time been separated only by a difference of opinion as to the expediency of the American war, were now all jumbled together; Fox coalescing with North, in order to oust from office some of his own Whig coadjutors, and Burke, not long after, strenuously maintaining, and not without success, his perfect consistency in being at the same time an old Whig and a new Tory.

Parliamentary reform - a change which would take the control of Parliament out of the hands of the "oligarchy of borough-mongers" - had been for some time loudly demanded. Political adventurers, such as the younger Pitt, ready to serve any party able to raise them to the head of affairs, had adopted the advocacy of such a reform as a likely means of political elevation; and, in spite of the opposition of Burke and other able servants and retainers of the borough-mongering interest, some such reform seemed likely to be speedily carried. 
The breaking out, indeed, of the French revolution excited hopes in Great Britain of something even more thorough than merely the annihilation of rotten boroughs. It first called into existence ideas of radical reform - in other words, the ultimate establishment of a democratic republic. But the reaction occasioned by the French reign of terror, and the anti-Jacobin war into which the nation was plunged, enabled the "oligarchy of borough-mongers," now under the leadership of the younger Pitt, by the help of a little reign of terror of their own in Great Britain, and a great one in Ireland, still to retain the management of affairs.

This general conservative reaction gave a new impulse to the mystical reaction already commenced in England, and which now spread rapidly over the continent. Previous to the French revolution, the higher orders throughout Europe had become, almost to a man, more or less Freethinkers; but they began now to feel the necessity, if they would have the people devout, of themselves setting the example. This reaction, in common with the other, extended even to France; and when Bonaparte, through the splendor of his military achievements and his influence with the soldiers, was enabled to take advantage of the current of counter revolution to make himself, first consul, and then emperor, one of his earliest acts was a concordat with the pope, and the relegalization of the Catholic worship.

In England, the new Whigs, of whom Fox was the founder and chief leader, contented themselves, so long as the war with France lasted, merely with opposition to that. To judge from the pages of their 
organ, the Edinburgh Revievw, they seem, indeed, to have been just as hostile as the Tories to any thing like radical reform. The restless and insatiable ambition of Bonaparte coöperating with and stimulated by the necessities of his position, rallied, at length, all Europe against him, people as well as kings, including even the British Whigs - a rally which brought about his double dethronement, and, with the further progress of the reaction, the modified reëstablishment of the old French monarchy.

Beginning now sensibly to feel the enormous burden, in the shape of debt and taxation, which the anti-revolutionary war had imposed upon them, a section of the British middle class, seconded by the manufacturing operatives, who had come, at last, to take an interest in public affairs, and to claim for themselves a participation in political power, renewed the call for parliamentary reform, as a first step towards infinite other reforms. This demand was quieted, for the time, by the help of the standing army, relieved from service abroad, and now employed at home to disperse the public meetings at which these changes were demanded. But, with the continued depression of trade and manufactures, no longer fostered by war monopoly, war demand, and immense expendiures on credit, this call for parliamentary reform grew louder and louder; till at length the faction of the Whigs, kept almost as long in a minority as the Tories had been during the reigns of the first two Georges, began to reëcho it, as a means of once more getting into power.

The government established in France after the overthrow and expulsion of Bonaparte assumed a 
decidedly municipal character. Louis XVIII. granted a charter embracing all Frenchmen, as his predecessors had granted charters to particular cities. At the same time, this new charter government presented very much the character of a close corporation the right of voting for members of the Chamber of Deputies, who shared, with a house of hereditary peers and with the king, the power of legislation, being limited to about a hundred and fifty thousand individuals out of a population of some thirty millions.

In the western part of Germany, the French revolution had overthrown the old social system hardly less thoroughly than in France itself; and the same effect was felt to a considerable extent in Italy and the Spanish peninsula. The German empire, and the ecclesiastical princes of Germany, reigning by the choice of their clergy and the confirmation of the pope, disappeared from the scene, as did also all of the imperial cities but four, and all but one or two of the sovereign counts; reducing the members of the Germanic body - now transformed into a confederation - from near three hundred to less than forty. Venice and Genoa; nominal republics, which had lagged so far behind the age to which they belonged, werc now at last, too, absorbed by their regal neighbors. Holland also became a kingdom, with Belgium reannexed to it. Of all the old European republics, the Swiss confederation and four German cities alone survived.

Spain, in its efforts to expel the French, had organized itself into a burgher monarchy; and the German princes, anxious to secure aid against Bonaparte, had promised to their people also constitutional govern- 
ments. But only a few of the weaker of them partially fulfilled their promises, while, by the help of the holy alliance between Russia, Austria, Prussia, and the restored Bourbons, for the protection and sustentation of religion and legitimacy, even the free constitution of Spain was suppressed, as well as the attempts of the Italians to obtain a share in the administration of affairs. The leading member of this holy alliance was Russia, - now first prominent in the affairs of Western Europe, - a country in which the influences of hereditary respect and of mystical ideas were still in full force, giving vast energy to the imperial power - influences which in Austria also were still very powerful.

Surrounded and instigated by returned emigrants, (remnants of the old régime,) and by priests of the revived order of the Jesuits, (fruits of the mystical reaction,) Louis XVIII., and his successor, Charles X., unable to forget the, old monarchy, as they remembered it previous to the meeting of the National Assembly, struggled hard to revive that old régime in all its forms, and especially to reëstablish the old privileges and influence of the nobility and clergy. But this was quite against the bent of the Paris bankers, shopkeepers, and property holders, - the new burgher aristocracy of the revolution, - who took occasion, from an attack upon the press, to make a street insurrection against Charles $X$., in which the operatives joined, and which resulted in his dethronement and banishment from France.

After some contest - whether a republic should not be proclaimed - with the members and adherents of the old Jacobin party which still survived, and 
always showed its head in times of commotion, it was resolved to pacify the still strong reactionary prejudice of Europe in favor of monarchy, by selecting a new king; to which post Louis Philippe was recommended, not only as the head of the younger branch of the old royal family, but as being, from his immense landed possessions, and other wealth, the richest man in Europe - the very recommendation of all others for a burgher monarch. The charter, no longer, as at first, the mere gracious grant of a legitimate, hereditary, and self-ruling king, became now the act of the nation. The hereditary peerage was abolished in favor of a peerage, or senatorship, for life - such as Hamilton had recommended for adoption in America. But the elective franchise was only very slightly extended; and the intense concentration of all power in the central administration, begun by the National Assembly, carried out by the Jacobins, perfected by Bonaparte, and continued by the Bourbons, was still retained in all its despotic rigor - an organization fitter for a camp than for a commonwealth, and putting liberty, in any sense in which that term is understood in America or Great Britain, quite out of the question.

'The thrill of the French revolution of 1830 was felt throughout Europe. The unfortunate Poles were stimulated by it to an insurrection which resulted in their more complete subjection to the power of Russia. Belgium, through the influence of religious antipathy, separated itself from Holland, but reorganized itself under a constitution still more liberal; while Portugal and Spain, by the fortunate accident of three disputed successions, were enabled to reëstablish their burgher 
monarchies, and greatly to reduce the political power of the clergy by confiscating the greaterepart of their property.

The expulsion of Charles $\mathrm{X}$. from the throne of France frightened the British "borough-mongers" into yielding up, to a considerable extent, the control they had so long exercised over the House of Commons. The great body of the burgher class - the mere operatives being still rigorously excluded obtained, by the reform bill, the right to vote. But, partly from the unequal ratio of representation, the influence of wealth in the British isles still vastly preponderates over all the other elements of power; and the oligarchy of the very rich, greatly as they dreaded and deprecated the operation of the reform act, find themselves still able to command, by influence or by bribery, - which, however the laws may affect to discountenance it, is as much a part, and as essential a part too, of the existing British constitution as the House of Commons itself, - a controlling power in that body quite sufficient, if not to dictate its action, at least to shackle, to limit, and to regulate it.

The disgust of the manufacturing operatives at being wholly overlooked in the new distribution of suffrage, and the formation, in consequence, of a new and separate party, under the name of Chartists, - a new feature in British and European politics, has greatly tended, temporarily at least, by dividing the radicals into two hostile factions, to strengthen the hands of the conservative section of the British burgher aristocracy, into which, at last, the old feudal aristocracy has been completely absorbed - the conservative party of Great Britain having lately had for 
chief leaders the son of a Yorkshire cotton spimmer and the son of $a^{*}$ colonial portrait painter; while one of its present principal heads is but a burgher novelist, enriched by marriage and elevated by talent. Upon one point, however, that of the prohibition or excessive taxation of imported food, - a policy designed to raise the rents of the landholders, - the growing predominancy of the manufacturing interest has at length prevailed, and unrestricted commerce - undoubtedly for the benefit of the British, however it may operate upon other nations - has become the settled policy of the empire.

Simultaneously with the gradual replacement, by an aristocracy of wealth, of the old feudal aristocracy of caste, the monarchical power, founded on similar ideas, may be said to have become extinct in Great Britain. The monarchical forms are still indeed preserved, and at a great expense too - an idle king or queen and a large royal family being still exhibited to the admiring gaze of the great and little vulgar. But however, from education, habit, or policy, the better informed may join in keeping up this solemn farce, every sensible person in Great Britain knows that the queen, politically speaking, is nobody, all the prerogatives of the crown, even to the appointment of her bed-chamber women, being exercised by ministers, indebted for their posts not in the slightest degree to her choice, but exclusively to the favor of the House of Commons.

But if the feudal age system has so far died out in Great Britain, that the power of the monarch and of the nobility of caste is at an end, that is far from yet being the case with the influence of mystical 
ideas, which still cast a malign shadow over the social condition of the British nation.

All the various religious organizations, of which the power had greatly diminished, felt the effects of the reaction which followed the French revolution. Even the Catholics vindicated, after a long and bitter struggle, their claim to equal participation in political rights - a participation conceded at last through fear, as the extension of the franchise was soon after; and, through the Irish, whose votes the Catholic priesthood control, they have risen from the lowest point of political degradation to be a formidable power in the state.

The Presbyterian clergy of Scotland were even encouraged by the growing force of mystical ideas to put forward claims to an authority independent of the civil power, and in derogation of the vested rights of patrons, the rejection of which has been followed by a secession, and the organization, with great funds, of a new and influential ecclesiastical association, under the name of the Free Church - a schism, however, from which mysticism is likely to reap but small fruits. From the same source have sprung the similar efforts of the Puseyites to carry back the English church to the days of Archbishop Laud. The English dissenters magnify themselves meanwhile on the sturdy resistance which they maintain against the political and spiritual pretensions of the established clergy, - that is to say, against the influence of mystical ideas embodied in that form, - a warfare which they push even to the extent of preferring that the children of the poor shall go untaught to read, rather than have them simultaneously instructed in the church catechism. And yet these very dissenters, thus pluming themselves 
on opposition to the church, have been, and are; among the chief instruments in upholding it. A large proportion of the converts whom they so assiduously make to mystical ideas, so soon as they obtain wealth enough to be of any political weight, strive to recommend themselves to the favor of the aristocracy, into which they seek admission, by abandoning the conventicle and going back to the church, which, without this constant replenishment, would scarcely have zeal and vigor enough, spite of its great wealth and its share in the legislative authority, to sustain, even so well as it does, its hold on the public mind. What the mendicant orders were during the middle ages to the church of Rome, the dissenting organizations, little as they wish it, have been, in a measure, to the church of England. Take away from the church of England its evangelical and its Puseyite elements, - elements directly traceable, as we have seen, to Methodistical influence, - and what would there be left of it? As it is, the church is strong, and a great stumbling block in the way of all political reforms. Nor is that even the worst of it. In contemplating the future of Great Britain, the most discouraging thing about it certainly is fierce religious quarrels already pending, and the bitter sectarian hatred which they engender.

At an early day of the French revolution, the negro slaves of the flourishing French colony in the western part of St. Domingo had risen against their masters, and with amazing energy had resisted all the attempts, first of the British and then of Bonaparte, to resubject them. Hayti thus became the second independent state of America, the United States being 
the first. The attempt of Bonaparte to grasp the crowns of Portugal and Spain had also furnished occasion and opportunity to the Portuguese and SpanishAmerican provinces to vindicate their independence. Those civil wars, by which the Spanish-American republics have been so much distracted, - another severe stab, not merely at the theory of the equal rights of man, but at the idea of the capacity of mankind for self-government, - have been almost entirely occasioned by the great inequalities of wealth, and that predominating mystical influence which the old system had left behind it; having been, for the most part, a struggle between the priests and a small body of very wealthy proprietors on the one hand, and the mass of the small proprietors on the other, with some episodes of military usurpation, personal rivalries, rustic insurrections, and accidental disputes. The mass of the people, consisting of aboriginal Indians, and freed slaves of African descent, or a mixture of these with the Spanish blood, have been too ignorant to perceive their own interests or to act with any steady combination or aim; nor, except in Guatimala, have they exercised any considerable influence on the progress of events, which seems, however, to tend decisively towards the triumph of the small proprietors, the subdivision of landed domains, and the establishment of governments upon a comparatively popular basis.

Had Louis Philippe and his advisers comprehended the nature of his position and the true interests of France and the world, they had a post of advantage in the French charter, meagre as it was, whence they might gradually have initiated the French people 
into the art of self-government - an art not to be learned in a day, and for which, without practice, no amount of mere science or theory will suffice. That initiation on the part of the French people might, it would seem, have been peacefully and successfully accomplished by gradually intrusting the communes with the management of their own affairs, and by a corresponding extension of the right of suffrage. But the Orleans dynasty had its own battle to fight for existence as well against the religious and sentimental retainers of the Bourbons as against the republicans, the hands of both of whom would have been strengthened by any extension of popular rights. The French statesmen, too, had their own nests to feather; and even those few whose patriotism and disinterestedness were beyond question, invincibly impressed in their youth with the reactionary spirit, and confused, rather than enlightened, by their learning, could not see in Europe as it now is any thing beyond the feudal ages, or at least the hardly less obsolete precedent of the English change of dynasty from the Stuarts to the Guelphs. Such was the spirit in which M. Guizot sacrificed himself and the Orleans family to a pedagogical attempt to prevent the eating of a political dinner an attempt which threw the boys into an uproar, and ended in a new barring out.

Though every body knew that the seat of the citizen king was not over secure, the dethronement of the Orleans family was, however, at the moment, entirely unexpected, resulting a great deal more from the extreme political weakness of the Orleans dynasty than from the strength of any body else. France 
being thus suddenly left without a government, a dozen gentlemen of good courage and various opinions, poets, journalists, and old Jacobin conspirators, volunteered themselves as temporary dictators; and though their claim to act as such had no other basis than their superior energy and force of will, it was, for the moment, favorably admitted. Under their auspices, a Constituent Assembly was elected by universal suffrage, which, not being able to agree upon any thing else, agreed upon a republican constitution - its most marked features being a legislature chosen by universal suffrage, and a president chosen in the same way, for a short term indeed, but the old despotic system of centralization being preserved almost entire, with a tremendous concentration in his person of executive authority, including the unrestricted command of a standing army of four hundred thousand men.

The Bourbons - both those of the older and those of the younger branch - being now in exile, the Bonapartes, who had taken the opportunity to return to France, were the only family in whose favor could act those ideas of hereditary respect, always so influential with a rude rural people like the mass of the French proprietors and cultivators. It was this sentiment, - and his perpetual talk about the emperor "my uncle" shows that he had the sense to know it, - a great deal more than the support of any of the factions that hoped to use him, that made Louis Napoleon president.

The new Assembly, chosen by universal suffrage, was, as might have been expected, a faithful representation of the French people. The friends of the 
new constitution were a small minority in it; and their violent folly - for they had little idea, any more than any other of the French factions, of carrying any thing except in the old Jacobin spirit of seizing upon power with the strong hand - soon gave to the majority a plausible pretence for still further reducing their number by expulsion. So little regard had the large majority of this purged Assembly - composed of Bourbonists, Orleanists, Bonapartists, and miscellaneous political adventurers - for the written constitution under which they acted, that they did not hesitate to alter and curtail it even on the grand point of the right of suffrage; nor did they think of any thing else except to make it a stepping stone by which they might respectively mount into power, treading, at the same time, on the necks of their opponents. The president was just as false and faithless, and just as much bent on schemes for his own advancement, as were the different factions in the Assembly, all of whom he wheedled and deceived in turn, till, having secured the favor of the priests, having the army also, and the countless host of civil officials, under his constitutional control, and a host of creditors ready to make new advances for fear of losing all, he did what, with all these aids, it surely was no great feat to do ; what, in fact, the majority of the Assembly had itself already done to a minority of its own members - dispersed it by military force, under the sufficiently plausible pretence of conspiracy against the president's authority and person; appointed himself, first, president for life, with unlimited power, and next emperor; and finally got these pretences sustained and these proceedings ratified by an overwhelming popular vote in his favor. 
The child catches many a fall, but learns at length not only to walk, but to run; and self-government is not, any more than walking, a thing to be learned in a day, nor to be given up as impracticable on account of the failure, however disastrous or ridiculous, of a few first attempts at it. Though it is impossible precisely to foretell the future course of the French revolution, it is perfectly safe to say that France will not become an hereditary despotism in the Bonaparte family.

What greatly weakened the French republican party, and contributed as much as any thing else to the quiet establishment of the new imperial rule, was the division of that party, like the radical party in England, into two hostile sections.

The operatives of Paris, not content with that universal suffrage and vote by ballot, - the most which the English Chartists claimed, - put forth pretensions to the aid of the government in the reorganization of industry upon a new basis, such as might add the equalization of wealth to the equalization of political rights - an equalization of wealth without which, as they justly conceived, political equality could not exist.

These socialist demands for a new distribution of the products of labor are a logical deduction, perfectly unexceptionable, from the famous dogma of Adam Smitl, that labor is the sole source of wealth. If so, why should not the wealth thus produced go exclusively to those whose labor has called it into existence, instead of sticking to the fingers of capitalists and speculators?

But, respectable as the pedigree of this doctrine 
might be, it was not, on that account, any the less alarming to the property holders, who, in France, rather than be obliged to fight street battles for protection against the socialists, have, naturally enough, preferred the reëstablishment of the empire, even though with a Napoleon the Little at its head.

As usual, the political shock in France which tumbled down the citizen king was felt to the confines of Europe, and with the weakening that resulted of the bands of existing authority, new ideas, or rather old ones revived in the studies of professors, improved the opportunity to struggle for realization. Democratic opinions appear to have had but a small part in this movement. The revival of the Slavonic nationalities, the reconstruction of the German empire undertaken by a volunteer convention of jurists and scholars, even the restoration of the Hungarian constitution on its ancient model, were none of them but flitting ghosts of the past. Where the movement was democratic, as in some of the westernmost German states, it was greatly damaged by the socialist schism. Though baffled at first, the military aggregation of power in the hands of the King of Prussia and the Emperors of Austria and Russia - the last two combining and acting together - has naturally triumphed, at least for the hour, over the discordant and even hostile elements aroused against them. So ends that which we have called the Commercial Sub-period of the Burgher Age. Already a New Era has begun, of which we shall attempt, in a subsequent chapter, slightly to raise the veil. 


\section{PART THIRD.}

GOVERNMENTS IN THEIR INFLUENCE UPON THE PROGRESS OF CIVILIZATION, AND UPON HUMAN HAPPINESS IN GENERAL.

\section{CHAPTER I.}

DEFINITIONS OF THE TERMS LIBERTY, SLAVERY, AND CIVILIZATION.

IN all disquisitions concerning government, great use is made of the terms Freedom, Slavery, and Civilization. It therefore becomes necessary to ascertain and fix the sense in which these words are employed.

The terms Freedom and Slavery, in their proper original sense, have exclusive reference to the condition of chattel slavery or domestic servitude. Those subjected to domestic servitude are Slaves, those not so subjected are Free.

The term Slavery was first employed in a political sense to describe the condition of conquered tribes subdued by some hostile community. Frequently such conquered tribes were made actual slaves of, as in the case of the Helots subdued by the Spartans. In other cases they were permitted to retain their personal freedom and a portion of their property on condition of paying tribute; the government being 
sometimes transferred to a deputy, or proconsul, (to use the Roman term,) of the conquering tribe, sustained by a body of troops, and sometimes allowed to remain in the hands of the native chiefs by whom the tribute was collected and paid. Communities in this condition were said to be enslaved, and the throwing off the foreign yoke was said to be a vindication of their liberties.

The word Slavery was next employed to describe the political condition of those states which, after having enjoyed a republican form of government, had fallen under the control of an oligarchy or a single ruler. Such governments were called by the Greeks Tyrannies. States so ruled were said to be enslaved, and the overturning such a tyranny was regarded as the reëstablishment of liberty.

The word Liberty was employed by the nobles, the churchmen, and the municipalities of the middle ages, as synonymous with the preservation and extension of the privileges and the authority appertaining to, or claimed by, their respective orders. As conflicts often existed between the claims of these bodies, the word Liberty was often employed in very different and conflicting senses - meaning sometimes the power and privileges of the nobles, sometimes those of the cities, and sometimes those of the : church. Nobles, churchmen, and citizens, all united, however, in describing, as the vindication of liberty, that opposition which they all made at different times to the extension of monarchical authority; so that at length the word Liberty came again, as in the days of Greece and Rome, - and partly, perhaps, through the influence of the ancient classical writers, 
- to be used as synonymous with republicanism, or opposition to monarchy.

In recent times, the words Liberty and Slavery, when - employed to describe the political condition of communities, "are used in a much more general sense. In current speech, the word Liberty is synonymous with political equality, and the word Slavery with political inequality. The domination of the many over the few, especially when it is but a mere reign of terror, upheld not by admiration, but by fear, constitutes, indeed, that condition of things which we have already distinguished as Social Slavery, which seems to differ from chattel or domestic slavery only in this, that, instead of being the particular slaves of individual masters, the mass of the people are regarded and substantially treated as the common property of the aristocratic order, bound to labor, suffer, and submit for their benefit. It was in these senses that the words Liberty and Slavery were used by the partisans of the French revolution; and it is in this sense, more or less exactly apprehended, that they are used in current political disquisitions.

It ought, however, to be noted that the word Freedom, and its synonyme Liberty, are still occasionally used in that anti-social sense, so prevalent among the nobles of the feudal age, and proper enough to a barbarous state of society, in which they signify the absence of all restraints, the power of doing whatever one pleases - in other words, the power of inflicting injuries on others, and of plundering and oppressing the weak for our own benefit and pleasure, and at our own option. This is the sort of liberty which tyrants and despots enjoy; which thieves, slave traders, and 
grog sellers claim; and of which all bad men are ever enamoured, who always raise a loud cry against every new law which goes to protect others against their depredations.

\section{"They bawl for freedom in their senseless mood, And still revolt when truth would set them free; License, they mean, when they cry, Liberty, For who loves that must first be wise and good." *}

It is, indeed, only as a means of curtailing this anarchical liberty of doing wrong, and of subjecting men to a mental necessity of doing right, that governments become objects of moral approbation, and deserve and receive the support of good men.

The progress of civilization - to the definition of which word we now proceed - may be considered as including four distinct heads : first, the advancement and diffusion of knowledge, which implies a great extension of the range of human pains, pleasures, and desires; second, the accumulation and diffusion of wealth, the chief means of gratifying these new desires ; third, the increase of the average force of the sentiment of benevolence, producing what is called the moral advancement of communities; and, fourth, an increased sensibility to several pleasures and pains - the sensibility to which, from certain resemblances and relations which they have, is commonly designated by the word Taste.

These four branches of civilization always tend, in the long run, to promote each other; nor can the progress of either be continued to any great extent, except simultaneously with the advancement of the 
others. Yet frequently the means by which an immediate or apparent advancement of one of these objects may be obtained is in direct opposition to the progress of the others; whence have arisen great confusion of ideas and numberless disputes and contradictions between philosophers, political economists, moralists, and critics, who have taken too narrow a view of things, and, instead of seeking to advance these four objects simultaneously, have sought to push forward one of them in preference to, if not to the neglect and sacrifice of, the rest. 


\section{CHAPTER II.}

EFFECT OF THE DIFFERENT KINDS OF GOVERNMENT.

\section{Section First.}

Test of the Degree in which Governments inflict Pain.

Although every exertion of power tends to inflict a pain of inferiority, it does by no means follow, as some have imagined, that governments are unfavorable to happiness in proportion to the power which they exercise. Even without reference to the pleasure which those who govern derive from authority, - an important consideration, not to be overlooked, - and taking into account only the welfare of the governed, government has three great objects, each containing many particulars, neither of which can be accomplished without great exertions of power. These objects are, first, the protection of the community against - aggressions from abroad; secondly, such works of - utility as are beyond the power of individuals to execute, or the utility of which is of so general a character that no individual in particular has any special motive to undertake them; and, thirdly, the internal suppression of plunder, fraud, and private violence, by the establishment of tribunals for the settlement of all private controversies, and means for the prevention, detection, and punishment of violations of laws of which the public good requires the enforcement. For the accomplishment of these objects, a very high degree of power is essential; and a 
government not possessed of that power is almost worse than no government at all, since it excites hopes which it fails to fulfil, and prevents the citizens from providing for their own security, though itself unable to defend them.

This weakness of government-a fruitful source of individual misery - springs frequently from ignorance of what it ought to aim at, still.oftener from ignorance as to the true means of accomplishing those aims; but frequently, also, from an excessive degree of power possessed by individuals or factions or orders in the state, hostile to the executive authority, and laboring to paralyze or to counteract it.

The inconveniences thence arising, and the absolute necessity of a great concentration of power for the discharge of those functions of government essential to the public welfare, will serve to explain the preference, already alluded to, which some benevolent and enlightened men have entertained for absolute monarchies, and especially for theocratic governments. But an unanswerable objection to such governments is, that the concentration of power thus brought about is very apt to be employed, not in the promotion of the public welfare, but in promoting the interest of a few; or, more properly speaking, the interest of those few is mistaken for the public interest, the masses being too much crushed under such governments to be reckoned as a part of the body politic.

The true test of the degree of pain which a government inflicts is to be sought, not in the extent or degree of its power, but in the opposition, active or passive, which it encounters - that is to say, in the degree of hatred which it inspires. 


\section{Section Second.}

\section{Operation of Governments founded upon Conquest.}

Tested by the rule laid down above, governments founded on conquest must be reckoned as the most oppressive and painful of all. A certain portion of the inhabitants of a country, who have come into it as invaders, and who maintain themselves in authority by the possession of arms, superior courage, warlike skill, and combination, lord it over a certain other and almost always a much larger portion of the inhabitants, who have been subdued and disarmed, and, if not plundered outright, which generally happens, subjected, which amounts to much the same thing, to the payment of a heavy tribute, now in rent, and now in taxes. Such was the government of the Roman republic over the subject provinces, and of the Ottoman Turks over the countries which they subdued; and such still is, with certain modifications, the government of the English over Ireland and India. No wonder if this sort of subjection receives the name of slavery, since it bears, in fact, a very strong resemblance to that condition.

In process of time, and after the generation of the actual conquerors and actually conquered has passed away, as, for instance, in Ireland, - if, indeed, we can properly refer, in this point of view, to a country always on the verge of rebellion, and in which the process of reconquest has to be constantly renewed, the extreme bitterness of this kind of government becomes somewhat mitigated. It is no longer sup- 
ported merely by force upon the one side, and by fear upon the other. Admiration begins to intervene; and traditionary respect, the idea of property in power, and sometimes mystical ideas exert a certain influence in its favor.

Where the body of conquerors is small, they sooner or later become amalgamated with the conquered, as happened to the Franks in France, and to the Normans in England, and, to a great extent, to the English and Scotch in Ireland; and thus that distinction of caste which seems always to originate in conquest, and which is the source of numberless antipathies and infinite mischief, gradually disappears. So long, indeed, as difference of caste, or, what is but a modification of the same thing, difference of creed, is made the foundation of political distinctions, so long are good government, social union and coöperation, and a high tone of morality quite out of the question.

It may and often does happen that, for the mass of the people, conquest is little more than a change of masters, and that the exactions and severities of the new governors are little or no greater than those of their former rulers. Sometimes the conquerors are even welcomed, as promising relief from intolerable burdens. But in general, however oppressive an existing government may be, - that is, if its existence has been of any considerable continuance, - some ideas of property in power and of traditionary respect have been established in its favor; so that the mass of the people, however oppressed, yet see not without sympathetic suffering the misfortunes and downfall of those to whom they have been long accustomed to look up as their rulers; while they have a dread 
and horror of strangers, from whom they anticipate all sorts of injuries.

Time, as has been already stated, may gradually diminish the intensity of this feeling; but it will still continue to exist so long as the conquerors are distinguished from the conquered, whether as an order of nobility, a religious sect, a separate caste, or a dominant racc - distinctions in many parts of Europe not yet by any means extinct, and unfortunately in most parts of both North and South America still prevailing in full force.

Such governments must also be regarded as exceed-

- ingly hostile to the progress of civilization; a state of painful uneasiness being alike unfavorable to the increase of knowledge, the exercise of benevolence, and the cultivation of taste, all of which require a certain calmness and freedom from pain; while the insecurity of such governments are highly unfavorable to the production of wealth. These drawbacks, however, operate with much less force upon the governing class, which may, as in Ireland and many parts of Eastern Europe, and in the slave states of America, make a considerable advance in civilization, while the inferior class remains plunged in utter barbarism. The civilization, however, of such states seems to be always superficial and at second hand - almost all those articles of convenience and elegance which civilization brings into use, including books, instead of being produced at home, being obtained by importation from abroad.

This oppressive class of governments founded upon - conquest includes every great empire, at least in its origin and earlier period, of which we have any 
knowledge. It must also be considered to include all governments, of whatever nominal character, in which chattel slavery exists; since slaves or persons of low caste are always the remnants of conquered tribes, of else captives in war, or their descendants.

\section{Section Third.}

Of Tyrannies, or Governments supported by Mercenary Standing Armies.

Next to governments founded upon conquest may be reckoned, in the degree of pain which they inflict upon the subjects, Tyrannies - under which head we here include all governments, whatsoever their form, which sustain their authority chiefly by means of $a$. mercenary standing army. This sort of governments has, indeed, a very close resemblance, in some respects, to governments founded upon conquest; since military force on the one side, and fear upon the other, are the main supports of both. But in general, they are far from having the same insolent and lawless character. A mercenary army is always under more strict and regular discipline than a feudal militia. These governments also possess the great advantage of being free, or of tending to become so, from the spirit of caste. Frequently they have the merit of destroying it, and of establishing in place of it the complete legal equality of all the subjects - a process which, painful as it may be to those of the superior rank, is always highly agreeable to the much greater number of the inferior order. A reader of Tacitus 
might wonder how the Romans could submit to the atrocious rule of such tyrants as Tiberius and Nero. But it must be recollected that the cruelties of these emperors touched only a very small body of Roman nobles, at whose humiliation and suffering the great mass even of the Roman citizens may be supposed to have been rather pleased than otherwise; while the vastly greater body of Roman provincials cared nothing whatever for the matter. The distinction between Roman citizens, allies, and mere provincial subjects, which had sprung out of the Roman conquests, in full force while Rome remained free, - to use the phraseology of republicanism, - rapidly disappeared under the imperial rule; till finally, by an edict of Caracalla, (A. D. 212,) the whole mass of Roman subjects not chattel slaves were recognized as Roman citizens; thus obtaining, by gradual and peaceful concessions, a privilege which, in the times of the republic, the Italian allies, to whom Rome owed so great a part of her conquests, had extorted only by a dangerous civil war. This privilege, it must be confessed, had lost, in the interval, a certain part of its importance; yet it still had a value by no means to be disregarded.

Tyrannies uniformly originate from commonwealths, and imply the preëxistence of a considerable degree of civilization, since it is only in states somewhat civilized that mercenary troops ever come into use. And, generally speaking, the old laws and political usages are still kept up, so far as is consistent with the new system, and perhaps are, in some respects, improved. Such was the case with the earlier Roman empire, and such were the transient tyrannies of Cromwell and the elder Bonaparte. 
In their general freedom from the spirit of caste and hostility to it, in thcir comparative order and moderation, and, in consequence of the foundation on which they are built, in the superiority of the means which they employ for the protection of private rights, governments of the kind we are now considering are, in general, far more favorable to the progress of civilization than those governments founded on conquest, to which they have such strong points of resemblance. And especially is this the case when the administrators of these governments, as often happens with their first founders, are men of superior ability, admiration of whose talents softens the pain of subjection to them. Many rulers of this class have, indeed, given great éclat to their empire by the encouragement which they have afforded to literature, and to the elegant and useful arts - a politic proceeding on their part, both as a present means of strengthening their power, and a contrivance for securing that favorable opinion of posterity, the desire for which is seldom without a certain weight in the conduct of affairs. So gracious, indeed, is the sound which the patronage of Virgil and Horace has given to the name of Augustus, that even the cold-blooded murder of Cicero has failed to leave so deep a stain as it ought upon him who so ungratefully consented to it.

\section{Section Fourth.}

\section{Of Theocracies.}

Wiru respect to governments founded on mystical ideas, commonly known as Theocracies, it is not so 
easy to assign their proper place in the present scale. When the mystical influence is complete and universal, such governments appear to be the least painful, as well as the most potent, of all, supported as they are by a zealous, ready, and devoted obedience, even to the sacrifice of life itself. Such was the loyalty of the subjects of the prince of the Assassins; and a like complete and unhesitating devotion has been exhibited by many other religious sects towards their spiritual and temporal heads.

In other cases, before the mystical influence is completely established, or after it begins to decline, mystical rulers, anxious to reënforce or to retain their authority, often resort to such atrocious cruelties as to excite against them the highest degree of hatred. Witness the outrages inflicted under such circumstances upon those who are denounced, not merely as rebels, but as infidels, or heretics. Witness the court of the Holy Inquisition. The most diabolical actions recorded in history have originated in the influence of mystical ideas. The love of power or of wealth, or the fury of hatred and revenge, by which men are so often and so powerfully impelled to the infliction of injuries, are and always must be restrained, in a greater or less degree, by the moral sentiment. But mysticism rises above all restraint, and even presses the moral sentiment itself into the service of torture and plunder. The atrocities of which the Spaniards were guilty in the new world did not so much arise from lust of money or desire of domination as from religious bigotry. The furious hatred with which the Catholie religion was, and, indeed, still is, regarded by many Protestants, had an origin natural enough the autos-de-fe - the "acts of faith" - the tortures and 
burnings inflicted by the Popish olergy, in the vain struggle to preserve their power.

But whatever may be the amount of pain, whether great or little, which theocratic governments inflict, they are the most fatal of all to the advance of civilization. The best they ever do, or can do, is, to keep things stationary. Under the most favorable circumstances, they may preserve that civilization which already exists. But that is all. 'The least increase of knowledge - and the increase of knowledge lies at the bottom of all progress - is watched and repressed with the most zealous severity, as striking at the very foundation on which mysticism rests. To eat of the forbidden fruit of the tree of knowledge of good and evil, is esteemed and punished by every theocracy, not only as a spiritual misdemeanor, but as an offence against the government. From Thales, Anaxagoras, and Socrates, down to Galileo, Newton, La Place, Humboldt, and the whole modern school of chemists and geologists, hardly a man who has contributed in the least to the advancement of knowledge has escaped, at the hands of the mystics, the dangerous charge of impiety. Even at the present moment, what hosts of "periodical heresy hunters" - to borrow an expressive phrase of Carlyle's - stand ready to pounce, like a flight of hornets, and with all the savage rage of so many officials of the Inquisition, upon any unfortunate author who, upon any point of metaphysics or morals, ventures to think for himself, or to step aside in the least from the beaten orthodox track! If such be the case in countries which boast of religious freedom and liberty of opinion as a guarantied constitutional right, and 
where the government professes to act irrespective of mystical influence, what is to be looked for where these very "heresy hunters" are themselves the rulers?

To supply the place of the pursuit of knowledge, to occupy the thoughts, and to keep the mind from wandering into forbidden paths, a ceaseless round is enjoined of ceremonial mummeries, which serve at once to engross and to stupefy the intellect. In a community in which every thing is reduced to a regular routine, - all experiments and novelties being looked upon as dangerous, at least, if not impious, - wealth cannot be expected to increase with much rapidity, Europe during the whole of that era which we have denominated the Middle Period, and India at the present day, unite to prove that where mysticism is predominant, taste and the average force of the sentiment of benevolence sink both to a point sufficiently low. The popedom is probably the most stationary government of all Europe, not even that of Turkey excepted; besides being, at the present moment, most hated by those whom, by the aid of foreign bayonets, it holds in subjection. The newest and most modern of all theocracies is that of the territory of Utah, so lately planted among the Rocky Mountains by the Mormons-a community whose origin and progress are calculated to throw great light upon the earlier and always exceedingly obscure history of mystical governments. Flourishing as yet in the vigor of early enthusiasm and willing obedience, this new American theocracy has a long career to run before reaching the decrepitude of the papacy. Together they might afford a pretty complete view of the rise and decline of mystical power. 
GOVERNMENTS BASED ON HEREDITARY RESPECT. 243

Section Fifth.

Of Governments based on Hereditary Respect and the Idea of Property in Power.

Governments founded upon, or mainly sustained by, hereditary respect and the idea of property in power, - of which character most of the monarchies of Europe have been till lately, and still are to a considerable degree, - inflict upon those subject to them only such pains as result from the folly or wickedness of the administrators, from ignorance of the true ends of government, and from imperfections in the machinery of administration - defects to which governments of this kind are very much exposed. Nor do they in general, though doing little or nothing to prevent it, place, like those of theocratic origin, any purposed obstacles in the way of advancing civilization, which, in its progress, is sure to undermine the basis upon which they rest, and ultimately to bring about a revolution which throws power and the administration of the government into the hands of an aristocracy of wealth, capable of finally passing, by the process already pointed out, into a democracy.

The subjects of these governments never exhibit that slavish, abject bearing, proper to a conquered people, or to the subjects of a theocracy. Compare, for instance, the peasantry of Scotland and Ireland, poor and degraded as, they are, with the agricultural laborers of England. The character of the Scottish peasantry, and of the Irish peasantry also, notwithstanding the subjection of that country by the British, 
was formed under a government founded upon traditionary respect - the government of the clans, which, though extremely defective in its administration, and in individual instances violent and cruel, still allowed the subjects, if not a feeling of political equality, at least a feeling of blood relationship to, and of common sympathy with, their rulers; while the English peasantry, on the other hand, are the descendants of a people repeatedly conquered, and reduced to the condition of serfs, from which they very slowly emerged, and to which the weight of taxation levied in England, till very lately, almost exclusively on labor, joined to the doctrine of settlement and the administration of the poor laws, has again almost reduced them.

\section{Section Sixth.}

\section{Of Civic Aristocracies.}

$\mathrm{WE}_{\mathrm{E}}$ come now to civic aristocracies - governments mainly sustained by the accumulated wealth of those by whom the political power is possessed and exercised.

By way of distinction from aristocracies of caste, these may be called Open Aristocracies, or Aristocracies of Wealth - the possession of a certain amount of wealth being requisite to a participation in the government, and all who attain that amount of wealth being allowed to participate in it, being received, that is, as members of that limited combination in which are centred the wealth and along with it the political power of the state. 
These civic aristocracies are far more favorable than any of the preceding kinds of government to the advancement of knowledge and the accumulation of wealth. The accumulation of wealth becomes, in fact, under such governments, the leading object of pursuit and desire; and industrious occupations, as a leading means of it, especially the superintendence and direction of combined labor, rise above that stigma of contempt with which, under all the foregoing forms of government, they continue to be branded. Wealth, indeed, under all forms of government, is a great object of desire; but wherever the military spirit is predominant, - that is, in most governments founded upon conquest, - plunder is looked upon as the only honorable source of wealth; while in theocracies, and governments founded on hereditary respect and the idea of property in power, wealth is more commonly inherited than personally acquired - the acquirers being regarded as an order of persons very inferior to those who have inherited it.

Civic aristocracies, by the increase of wealth which they occasion, and the greatly increased security and sacredness which they impart to the laws of property, create a large class, possessed of abundant competency, or of sure and easy means of livelihood, thus giving to the love of knowledge, to taste, and to the moral sentiment, an opportunity for freer development, and for the acquisition of new force. Knowledge, indeed, in several of its branches, especially those relating to physical science, is zealously pursued in such communities, and the pursuit of it is warmly encouraged by the government, not, indeed, for itself merely, or as an agreeable employment of leisure, but as 
opening new and rich sources whence new accumulations of wealth may be derived.

As a general rule, governments of this kind are also administered with far more of intelligence and science than any of the preceding forms. Indeed, the aristocracy of wealth has proved, notwithstanding the sneers that have been flung at it by the devotees of hereditary respect and mystical influence, as well as by some over-zealous democrats, a form of government far superior in its practical administration and social results to most others.

However, it cannot be.denied that, under governments of this sort, with all their advantages, the subject elass often suffer severely from the exactions of their rulers, and hardly less so from their arrogance and purse-proud assumptions. At the same time, they are always consoled - and that is a great matter by the prospect, at least by the possibility, of becoming themselves members of the ruling class.

The great defect of civic aristocracies is one incident to all aristocracies, oligarchies, and monarchies - a constant ignorance and neglect of the wants and interests of the mass of the people, or the deliberate sacrifice of the interest of the mass to the interest, real or supposed, of a few. Upon this point, however, aristocracies of wealth present several alleviating considerations. The few whose wishes and interests they consult are generally more numerous than the few of any other form of government; and the transition from the class of the many to that of the few is much easier. The class of the few admits, in fact, in these civic aristocracies, of constant and indefinite expansion, till presently it ceases to be few, becoming, 
indeed, a majority of the.whole population, so that the government passes insensibly into a democracy. The distinction between the few and the many, and of course, also, the distinction between the interests and wishes of these two classes, is also less marked - the few and the many melting into each other by imperceptible degrees, while, in other governments of the few, these two classes are separated by abrupt and almost impassable barriers.

But, with all these recommendations, aristocracies of wealth are also attended by several disadvantages, which make them often very fruitful in pains, and oppose serious obstacles to social progress. The adventitious political importance which is attached under these governments to the possession of wealth, makes it an object of pursuit at all hazards and at whatever sacrifices. Nor is there any limit to this desire of wealth, nor means of satisfying it, since the political importance of each individual constantly increases with the increase of his wealth ; while the prospect of founding a family, and thus acquiring a sort of posthumous importance, gives to the passion for riches additional ardor.* The great accumulation of wealth

* The ardor with which the acquisition of wealth is pursued has been noted by many English travellers as a peculiar American trait, and has even been set down as a democratic impulse. It is true that in America, by virtue of its democratic system, the ardent pursuit of wealth is more general than in England. But the passion in America is much more easily satisfied, since, beyond a certain moderate limit, the increase of wealth adds little to 'social, and still less to political importance. We have, in America, no boroughs to be bought, no constituencies to be bribed, and no peerages to be purchased; whereas in Great Britain there is no end hardly to the social and political elcvation to be gaincd by money, which is not less eagerly sought by the very richest than by those who have still a competency to gain. 
which takes place in such communities is too often made to centre in comparatively a few hands - a result accomplished by means of monopolies, unequal taxation, and laws made by, and uniformly favorable to, the rich, who grow constantly richer, while the great mass of the laboring population are kept just at the door of the poorhouse, and with only that prospect before them in case of sickness or the decline of old age. The profuse luxury of the wealthy, the thousand new delights which they contrive for themselves, create in the minds of the poor a thousand new wants, which, as the means for their gratification are lacking, presently take on the form of pure pains - pains of ungratified and hopeless desire, pains of envy, pains of hatred. The poor denounce the rich as heartless tyrants and oppressors, rolling in luxury at their expense; the rich denounce the poor as envious, wicked, malicious, and ignorant. A mutual state of ill feeling springs up between these two classes, - wild projects for the equalization of power and property on the one side, and stern schemes of suppression on the other, - till presently the government can only sustain itself by employing mercenary troops to keep the masses in subjection. The government thus changes its character; its progress towards democracy is checked and counteracted; it assumes the characteristics of a tyranny, and tends constantly to become either an aristocracy of caste, - the masses being hopelessly reduced to the condition of social slavery, - or, what is more likely, an absolute monarchy - the masses being quite ready, for the sake of humbling a hated aristocracy, to assist in placing supreme power in the hands of a tyrant-a feeling which helped 
Louis Napoleon not a little to become Emperor of France. Nor have the masses any thing to lose by such a revolution, their condition being already - or, at least, so it seems to them - as bad as it can be.

\section{Section Seventh.}

\section{Mixed Governments.}

Such are the effects, so far as relates to civilization and to human happiness in general, to be commonly expected from governments founded upon conquests, from governments sustained by mercenary troops, from those erected upon mystical ideas, from those resting upon hereditary respect, and the idea of property in power, and from these wielded by wealth in combination. Sometimes, as in the case of Great Britain for example, all these various sources of power will be found combined, or at least aggregated - the . superstructure of the government resting, more or less, upon all of them. In such cases, however, these different elements of power are extremely apt to come into conflict with each other, thereby weakening instead of strengthening the government, which becomes nothing but a compromise among contending ideas. Hence the violent struggles in Great Britain between the landed interest and the mercantile and manufacturing interest; hence the struggle of the church - that is, of mystical ideas, and their recognized agents and depositaries - with the civil power, and of the various churches and church factions with each other - struggles by which the efficiency of the 
British government is often so impaired as to incapacitate it from applying remedies to the most obvious and acknowledged evils.

This, however, is far from being so bad a state of things as that which existed throughout Europe during the middle ages, when these different fragments of power were often at open war with each other, producing a degree of insecurity, confusion, and anarchy very hostile to social progress. The monarchical power in England may be considered, indeed, as at length fairly extinct - the monarch having become but a mere puppet, an "idle king" for show, in the hands of ministers selected by the House of Commons to administer the government. And though the continental states of Europe have so far gained upon England during the last sixty years, that the country which was then the freest from feudal shackles is now the most encumbered by them, yet these ancient feudal ideas, including the political influence of the church and that of noble birth, become, day by day, in spite of some feeble romantic attempts, whether lay or clerical, to revive the system of the feudal ages, more and more mere shadows, mere shams, like the pretended monarchical power - the predominating and controlling authority of the nation centring more and more in the hands of an aristocracy of wealth, with a tendency on the part of the more enlightened and humane portion of it to enlarge itself gradually into a democracy; which form of government it remains now to consider. 


\section{Section Eighth.}

\section{Of Democracies.}

IT is an idea very prevalent among the warm partisans of democratical government, - it is, indeed, the fundamental idea of Rousseau's famous essay on the Social Contract, - that there exists in the numerical majority of the people an exclusive right to control the community - so much so, that they regard the democratic form as alone legitimate, and all other governments as mere usurpations. But what basis can be found for this alleged right of the majority to govern, unless it be made to rest, like all other rights to govern, upon the superior strength, force, MIGHT of those who claim it? Here is a case, and this is the sense, in which Might makes Right. The majority have the right, present or future, to govern, or, rather, to decide upon the forms and policy of the administration, and to determine the particular agents by whom it shall be carried on, - since, in the most democratic governments, the actual exercise of authority is, and always must be, in the hands of comparatively a few,- because, and only so far as they have the might, actual or potential, to do so. Nor does any such right exist for any practical purpose, except so far as the majority possesses, not merely a potential, but a con- . scious superiority, supported by a discipline of combination which enables them to concentrate, in support of their authority, a greater mass of the natural elements of power than can be arrayed against them 
by any individual or any minority. Democratical forms do not, by any means, secure a really democratic administration. For that, two things are essentially necessary - a certain equality in the diffusion through the community of the primary elements of power, and the habit of the enjoyment and exercise of political rights. Whatever the nominal form of a government, the administration of it will speedily fall into the hands of those, whether one, a few, or a greater number, with whom the actual superiority rests; and, in general, the form itself will, sooner or later, be made to correspond to the actual character of the administration.

The duty, under democratical governments, of the minority to submit and obey, rests upon the same double foundation with the duty of obedience in other governments - first, upon the moral obligation which all men are under to submit to, and to use their best exertions in establishing and enforcing, all laws, by whomsoever made, which are plainly and clearly for the public benefit; and, secondly, upon the moral obligation which all men are under of submitting even to unjust laws, when forcible resistance to them would be productive of more evil than good - of submitting to, not of aiding in, their enforcement. Unarmed or passive resistance to bad laws is always morally right, for the reason that no popular majority has, any more than any other ruling power, any moral right to enact bad laws, whatever may be asserted to the contrary by those flatterers and parasites by whom the ruling power is beset, and stimulated to crimes, not less in democracies than under other forms of government.

Supposing a community in a condition to be capable 
of a democratic government, there is obvious, at the first glance, one particular in which that form has a great and singular advantage over every other. Under all other forms of government, the pleasure of governing - in other words, the pleasure of superiority, one of the greatest pleasures of which men are capable is confined to a small number. This number may, indeed, in aristocratical forms of government, be comparatively large - which circumstance has always proved, among the partisans of that form, one principal recommendation of it, as compared with monarchy or oligarchy. Thus, in civic aristocracies, or áristocracies of wealth, - the least objectionable, as we have seen, of all kinds of aristocracy, - however small the actual number participating in political power in comparison with the entire population, yet there extends to every member of the community a certain hope, prospect, or possibility of being, at some time or other, admitted into the privileged class. Still it is Democracy alone which has this great and peculiar advantage, that while all are obliged to submit to the pain of obeying, all are allowed to participate also in the pleasure of commanding. Every vote which the citizen of a democracy gives is an exercise, on his part, of a certain portion of the national sovereignty. Even though he votes in a minority, his vote is not without its influence on the conduct of affairs - a circumstance, leaving the character of the actual administration entirely out of the question, or even supposing it to be extremely bad, which always endears this form of government to the mass of those who live under it; clearly proving the falsity of that maxim current with a certain class of speculatists, 
that the form of government is of no consequence, that being best which is best administered.

With the vast majority of persons, the sentiment of self-comparison is sufficiently gratified by being allowed an equality with others. Every good citizen, whether good by nature or good by education, like every benevolent or merely well-bred man in the social circle, is content with an acknowledged and admitted equality - political in the one case, social in the other. $\mathrm{He}$ - does not ask any exclusive right of speaking and deciding for the rest, but, for influence over the decisions of his associates, relies upon his own personal possession of some of the original elements of power; for even in democracies, not only skill, courage, activity, knowledge, and wealth, but even hereditary respect, mystical ideas, and the notion of property in power, have always hitherto exercised a certain degree of influence - an influence, however, in the case of the last three, directly opposed to the nature of democracy, and too often resulting in its subversion.

Undoubtedly there are always to be found in demo- cratic governments, as in the social circle, a certain few to whom this condition of equality is sufficiently irksome - men in whom the desire of superiority is strong, while the sentiment of benevolence is weak. Generally, however, men of this character are of very moderate abilities, possessed with an overweening idea of their own wisdom and virtue, and full of ignorant contempt for others. Men of superior capacity, when they chance to live under popular forms of government, are very generally the greatest admirers and warmest supporters of those popular - forms; for the obvious reason that those forms, and 
those forms alone, open a high road to merit and to talent. It is not such men who are filled with fears lest the people should fall under the exclusive control of mere flattering demagogues. 'Though they may never have investigated the subject scientifically, and may therefore be unable clearly to state how they know it, yet they know well that admiration is the true basis of political influence; and they know, too, that, in order to excite admiration, there must be an actual or apparent superiority of some sort or other, the place of which all the demagoguism in the world can never supply.

But, besides this peculiar advantage of democracies, (that they allow all to participate in the pleasure of governing, and thus neutralize, in a great measure, the pains of obedience,) it is also clear that, even as regards the mere administration of affairs, the dernocratical form possesses special advantages. In other forms of government, rebellion and civil war, always dangerous and doubtful resorts, are generally the only means which the many can employ against the tyranny of the few. Under democratical governments, the ballot box always holds out the prospect of a peaceful change, both of rulers and of policy. Much, indeed, has been said about the dangers to be apprehended from a tyrannical majority. Grant that a majority, in possession of power, must of necessity be oppressive and tyrannical, sacrificing without remorse the interests of the minority; yet surely even that is a lesser evil than the predominancy of a tyrannical minority, sacrificing without remorse the interests of the mass. It is no doubt true that all possessors of power, whether individuals, minorities, or majori- 
ties, are strongly tempted, and are very likely to abuse that power, and that often nothing but fear will restrain them from it. But so far as relates to the influence of fear in restraining abuses of power, there is a great and most important, a remarkable, and, at first thought, hardly to be expected, difference between democracies and all other forms of government. In all other forms of government, acts of tyranny and oppression are comparatively safe; in democracies, they are always full of danger. All governments of the few may safely tyrannize to any extent, provided they stop short of provoking their subjects to actual insurrection. But in a democracy, the moment a majority performs a tyrannical act, it falls into great danger of ceasing to be a majority. A democratical administration is strong just in - proportion as its acts produce pleasure; it is weak just in proportion to the pains which it inflicts; and, among these pleasures and these pains, moral pleasures and moral pains have no inconsiderable weight. If the pains which the administrators of a democratical government inflict counterbalance the pleasures resulting from their ascendency, the administration is sure presently to change hands. An act of oppression against a single individual may, by its operation on the sympathies of the community, suffice to produce a political revolution, which takes place, however, by the regular operation of the mechanism of the government, without any disturbance of the public tranquillity. The only acts of oppression which even the largest majority, under a democratical form of government, can safely indulge in, are those which originate in, and are sustained by, a spirit of caste, or the influence of mys- 
tical ideas - two ingredients wholly foreign in their nature to democratical government, and essentially hostile to it, though sometimes largely mixed up in such imperfect democracies as have hitherto existed.

Municipal ideas having become generally diffused throughout the more civilized portions of the world, the people, the mass, or, rather, if we look at the actual facts, a number of speculative individuals in their name and behalf, are beginning to feel their might, and to claim their right. Hence the demands which have been made throughout Europe for extended, if not universal, suffrage and elective legislatures; and if, hitherto, these demands have failed to be enforced, we must attribute it to their not having yet so much been urged by the masses themselves as by others for them. The privileged few who now possess the control contend, on the other hand, with earnestness, that the only effect of the introduction of democratic forms would be, to take political power from the virtuous and enlightened, in order to transfer it to corrupt and self-seeking demagogues - the favorites and flatterers of an ignorant, vicious, senseless multitude, brutish, stupid, cruel, and wicked, unfit to be intrusted with power, incapable of discerning their own good, much less the good of the whole, and, even when they do discern it, ready to sacrifice it to the appetite, passion, or caprice of the moment, destitute of all respect for the institution of property, and ready to trample under foot all the obligations of morals, and, along with them, talent, sagacity, knowledge, eloquence, virtue, wealth, nobility, and religion.

But declaimers like these omit to consider, or, 
rather, perhaps, they do not know, that knowledge, sagacity, force of will, virtue, eloquence, wealth, traditionary respect, and the influence of mystical ideas are elements of power which, wherever they exist, cannot fail, especially under democratical forms of government, to exert an influence proportionate to their force. Suppose even universal suffrage and annual legislatures to be established, yet the elements of power above enumerated must still continue to exercise a power over the voters, enabling each individual in whom they are specially concentrated to exert an influence over his fellow-citizens in proportion to the degree and force of that concentration. Not only the actual administration of affairs, even in the most democratic communities, but the general tenor of public opinion, at least on all questions of expediency, must ever be controlled by comparatively a few. It is, and always must be, a small number, sometimes a single man, who, upon points often of the greatest importance, steers public opinion as the pilot steers the ship. The only questions are, whether the few or the one on whom this pilotage is to devolve shall owe their post of pilots to birth, priestly offices, wealth, inherited or acquired, or to reputation for superior knowledge, sagacity, and virtue; whether the number from among whom these few can arise shall be a limited number, or shall include the whole community; whether the one or the few once in possession of authority shall retain it for life, and transmit it to their children, or whether authority shall change hands simultaneously with the elements of power - and that, too, without any of those civil struggles, or of that violence with which such struggles 
are always attended, whenever the political system is not so contrived as to require those peaceably to surrender authority from whom the natural basis of it has departed.

That which may be said to constitute the special characteristic of democratic government, and at the same time its special and great superiority over all others, is this, that it introduces, under the shape of frequent elections, and a suffrage so extended as to include all who feel any interest in public affairs, a . standard - and for all practical purpose a sufficiently accurate one - for measuring and remeasuring, at frequent intervals, the degree in which the natural . elements of power, and of consequence the right to rule, appertaining to all such as present themselves, from time to time, as contestants for authority; thus, . by an obvious and palpable means, showing to the weak their weakness, giving also to the strong opportunity of proving their strength - a result under all other forms of government only brought about by irregular and spasmodic resorts to force, now on the part of those in power, and now on the part of those who would dispossess them; resorts which ever must be attended by an agony and crisis of the body social and politic, and which but too often aggravate the very evils they are employed to cure. From these terrible revolutionary and reactionary movements, imbittered by ferocities and stained with blood, democratical communities are happily free; that party which perceives itself outnumbered yielding with a good grace, well knowing that, whenever its superiority becomes manifest, the now triumphant party will yield in its turn. 
Undoubtedly there are a great number of communities, in which the mass of the people have been degraded and brutified for ages by theocratic or aristocratic oppression, in which a democratic government is wholly impossible. It may be established to-day, but it will be overthrown to-morrow. To the existence of a democratic government, to the application of the test - of the ballot box as above described, a good degree of equality, both in knowledge and wealth, is absolutely essential; and, on the other hand, it is equally certain that, where such an equality shall be established, democratical government will presently follow. Among communities unaccustomed (as the French, for instance) to practical participation in government, many failures may precede success. A child cannot learn to walk, neither can a nation learn to govern itself, in a day; yet, by patience and perseverance, both may be accomplished in the ordinary course of nature.

The partisans of aristocracy, the household poets and historians, the paid scribes of the noble and the rich, have too often, however, grievously belied and maligned the mass of the people. The mass are men, as well as the few, and not so inferior, either in discernment or moral feeling, as pride and prejudice are apt to imagine. Let us hear upon this point the testimony of a keen observer, of nice and discriminating judgment, of warm benevolence, too, but not likely, either from his education or his position, to be unduly biased in favor of the multitude. "One may generally observe," says Addison, in his Remarks on Italy, "that the body of a people has juster views for the public good, and pursues them with greater uprightness, than the nobility and gentry, 
who have so many private expectations and particular interests, which hang like a false bias upon their judgments, and may possibly dispose them to sacrifice the good of their country to the advancement of their own fortunes; whereas the gross of the people can have no other prospect in changes and revolutions than of public blessings that are to diffuse themselves through the whole state in general.".

So much for the influence of democratical governments upon happiness in general. Let us now briefly inquire how they affect the progress of civilization the increase and diffusion of knowledge and wealth, and the elevation of the standards of taste and morals.

Knowledge, wealth, and the gratifications of taste are such universal objects of desire, that men, if left at liberty to do so, will always pursue them; and may it not safely be concluded, that in proportion to the number of those who pursue will be the number of those who attain? Democratical governments, by reason of the very principle of equality upon which they are founded, are decidedly hostile to all monopo lies, restrictions, or prohibitions. They afford, or tend to afford, an equal chance to all competitors - that is, to the whole mass of the citizens; whereas, under all other forms of government, (unless a few civic aristocracies ought to be partially excepted,) the great mass of the people are cut off from all pretensions to knowledge, to taste, and to wealth. The pursuit of these objects being confined to a few, their diffusion, which is equally important with their acquisition, is, of course, confined within very narrow limits; while the amount acquired is also restricted by the small 
number of those "who adventure in the pursuit. Is there any thing to which the civilization of the present day is so much indebted for its rapid advancement as to the approach made of late, throughout Christendom, to free competition in the pursuit of knowledge, wealth, and the elegances of life?

As regards that part of civilization which consists in the increase of the ayerage force of the sentiment of benevolence, the most dangerous opposition to the dictates of the moral sentiment unquestionably originates in antipathies which grow out of the division of men into castes, mystical sects, and hostile tribes and nations. Now, democratical institutions are in direct opposition to the spirit of caste and to the influence of mysticism. They tend to produce a general spirit of humanity and philanthropy. They are equally hostile to that excessive admiration which can discover nothing bad or wrong, and which is ready to pardon every thing in those who are the objects of it, and to that arrogant contempt which can see nothing good or right in those against whom it is directed, and which can make no excuses nor allowances for them.

Under a democratical form of government, it is no longer possible for half a dozen different codes of morals, often in many points in flagrant contradiction to each other, to flourish simultaneously in the same community. In place of these various and contradictory codes, democracy gradually substitutes one code, one moral standard, by which the actions of all are to be judged; thus giving additional vigor to the moral law, which rules in democracies with a force that appears despotic to those unaccustomed to it, but which is only injurious in so far as the received moral code 
happens to rest upon a false basis or on mistaken notions, and which becomes salutary in proportion as that code becomes enlightened and complete.

M. de Tocqueville did very well to seek, in the United States of America, for information as to the working of the democratic system when applied to large extents of territory. But, in attempting to form a general judgment as to the social, moral, and intellectual influences of that form of government, he might have done better not to have confined himself so exclusively to that single example. Instead of, in the absence of facts, or in ignorance of them, setting down, as conclusions established, what, at the best, can, for the most part, only be regarded as plausible conjectures, might not that fluent but somewhat superficial writer have shed more light upon the subject by turning his attention to the history of Europe during the last eight or nine centuries; tracing there the municipal spirit, - in other words, Democracy, in its gradual rise from small and obscure beginnings; showing how it gave a commencement to the modern civilization of Europe, and though opposed by a thousand obstacles, and often, to appearance, almost extinguished, how it kept always spreading, always growing, till now at length it seems upon the point of producing that great social and political revolution which M. de Tocqueville clearly enough foresees and appears to regard as inevitable, but the true nature and real origin and progress of which he appears to be very far from having fully comprehended?

Those, indeed, who scek, in the history and present condition of the United States of America, for the practical workings of a democratical form of govern- 
ment, must make due allowance, if they would avoid falling into very grave errors, for the operation of several disturbing forces, of which the influence upon the institutions and social condition of America is far from inconsiderable.

The first of these disturbing forces is the English common law, adopted as the basis of American jurisprudence - a scheme for the administration of justice, whether civil or criminal, exceedingly defective, and in several respects, especially as now understood and interpreted by the courts, directly hostile to the spirit of democracy. In fact, the English common law, if we would form a true idea of it, ought not so much to be regarded as a system for the administration of justice and the enforcement of the laws, as a contrivance for setting aside the laws, and defeating the intentions of the legislative body, whenever those laws and those intentions fail to meet the approbation of the judges for the time being. Such a system, in certain states of society, - as a defence against the oppressions of those who possess the legislative power and are inclined to abuse it, or as a supplement to legislative ignorance, negligence, and incapacity, - is not without its utility. But, under an enlightened democratical government, it is entirely out of place - becoming, in fact, a contrivance to enable the few to defeat the wishes of the many.

A second disturbing force is to be found in mystical ideas, which, though not admitted to any open share in the administration of affairs, yet possess in all parts of the United States no inconsiderable degree of influence in all social matters. Hence that intolerant bigotry and bitter opposition to all freedom of inquiry, or speculation beyond certain limits, no 
less characteristic of the United States than of Great Britain, but more proper to a theocratic despotism than to a democracy, or even a civic aristocracy. It has been under the military monarchy of Prussia truth compels us to acknowledge it - that the freedom of speculative discussion, banished from America and Great Britain, has, during the last half century, found shelter. And yet it is to this foreign and even hostile ingredient that $\mathbf{M}$. de Tocqueville seems inclined to ascribe, in a principal degree, the success of the democratical system in America - a view which, if correct, would go very far to show that pure democracy is a thing not practicable.

The third and most powerful of these disturbing forces is, the existence of chattel slavery in the southern states of America, and of a spirit of caste, derived from slavery, in the whole of them - things in direct contradiction to the fundamental principles of democracy, and producing, in addition to many practical evils, an odd confusion of political ideas - laws, practices, and accepted theories being often strangely contradictory and incongruous. So long as slavery exists in the United States, or, at least, so long as the slaveholders enjoy a predominating sway in political and social life, it will be in vain to look to this quarter for the full realization of that modern democratical system which had its very origin, as we have seen, in the :epudiation of chattel slavery.

Besides the allowances to be made for these three disturbing forces, it ought also to be remembered that the United States are a country very recently settled, where the accumulation of wealth is but just begining, and throughout the greater part of which the 
dispersion and poverty of the people form serious, and as yet insurmountable, obstacles in the way of many social improvements, especially the cultivation of the sciences and the elegant arts. It might be as well for the good-natured critics and speculatists of Europe to wait a half century or so longer - and even that allowance would not be excessive - before coming to any final and dogmatical conclusion as to the blasting influences of democracy in these particulars.

Demócracy, in the municipalities and republics of Europe, has been mixed up, as it now is in the pseudomonarchy of Great Britain, with foreign ingredients still more numerous and more operative than those at work in the American states. The experiment, therefore, of a pure democracy, on any considerable scale, may be said yet to remain to be tried; though, of all states of which we know any thing, the northern, or free states of the American union, certainly come the nearest to it.

Traditionary respect and the influence of mystical ideas, as well as the idea of property in power, - that is to say; nobility and priestcraft, - are fast wearing out, and will, it is probable, cease presently, in all enlightened states, to be elements of power. Wealth and knowledge are also rapidly tending to a certain - equalization. But these two elements of authority, being, like strength, skill, sagacity, force of will, and virtue, forces inherent and persistent in human nature and human society, cannot fail, even under the most democratical form of government, to exercise their due degree of influence. Indeed, it is only under such a form of government that they can exercise their due influence, neither less nor more. 


\section{CONCLUDING CHAPTER.}

\section{HOPES AND HINTS AS TO THE FUTURE.}

IN the cursory view taken in a preceding chapter of the history of Christendom for the last eight centuries, we have found that period divisible, without any very great forcing, into four ages of two centuries each, during which the Clergy, the Nobles, the Kings, and the Burghers successively enjoyed a certain headship and predominancy. But, besides these four ruling orders, we have also, during these centuries, caught some slight occasional glimpses of arother order, to wit, the mass, - the delvers, agricultural and mechanical, those who work with their hands, - in numbers, at all times and every where, the great body of the people, but scarcely any where possessing political rights, and even where, by some fortunate chance, they have gained them, for the most part, speedily losing them again.

The clergy, the nobles, the kings, the burghers have all had their turn. Is there never to be an Age of the People - of the working classes?

Is the suggestion too extravagant, that the new period commencing with the middle of this current century is destined to be that age? Certain it is, that, within the last three quarters of a century, advocates have appeared for the mass of the people, the mere workers, and that movements, even during this age of the deification of money, and of reaction against the theory of human equality, have been made in their behalf such as were never known before. 
We may enumerate first in the list of these movements the indignant protest against the African slave trade, and the combination for its suppression into which the governments of Christendom have been "forced, by the efforts of $\mathrm{n}$ few humane individuals, appealing to the better feelings of their fellowcountrymen, and operating through them on the British and American governments. It has, indeed, become customary, among the advocates of money making, no matter by what means, - in which category we must place some London newspapers of great pretensions, - to sneer at the attempted suppression of the slave trade as a failure. It is true, that, by the connivance of the Portuguese, Brazilian, and Spanish authorities with scoundrel merchants, British and American, the trade still exists. But what is it compared with what it would be did it enjoy, as formerly, the patronage and favor of al? the flags? and how much longer is it likely to flourish?

We may mention next among these movements on behalf of the laboring class the abolition of chattel slavery in so many of the ultramarine offshoots from Europe; not alone by the strong hand of the slaves themselves, as in Hayti ; not alone in consequence of protracted civil war, - a consequence generally pretty certain to follow, - as in the Spanish-American republics; but also from a mere sense of shame and wrong, as in the now (so called) free states of the North American Union; and from an impulse of humanity and justice, even at a heavy outlay of money, as in the British tropical colonies.

We may mention further the subdivision which has 
been carried so far, in France, of the lands of that country among the actual cultivators; a subdivision objected to by certain British economists, as not so favorable to the production of wealth, a point, however, not to be hastily conceded-but which unquestionably does tend to give to the cultivators a certain social importance and political weight.

Let us add the system of savings banks, by which the English laborers for wages have been enabled to invest their savings in a comparatively safe and easy manner, and thus to share in that accumulation of wealth which forms so important an element of power.

Add further the constant advance and development of manufacturing industry, giving employment and high wages to a class of laborers vastly superior in intelligence to the stupid and thoughtless rustics by whom the fields of Europe are generally cultivated a class among whom have arisen those Chartists and Socialists whom we have had occasion to notice, towards the close of our burgher age, as claimants for political rights; a class, in fact, from which the larger portion of the existing burgher class has itself derived its origin.

Such are some of the social changes which may be regarded as precursors and signs of the approaching Age of the People.

If the mass of the people are ever to be raised above the servile position in which they have been so long and so generally held, there would seem to be only one way in which it can be permanently and effectually done, viz., by imparting to them a vastly greater portion than they have ever yet possessed of 
those primary elements of power, sagacity, force of will, and knowledge, to be backed by the secondary elements of wealth and combination. Nor does the prospect of thus elevating them appear by any means one altogether so hopeless.

Whatever objections may be made to the existing distribution of riches, and to the artificial processes by which it is regulated, - subjects which will form important topics of the Theory of Wealth, - this at least must be conceded, that no mere redistribution of the existing mass of wealth could effectually answer the proposed purpose of elevating the people. Any such redistribution, even if means could be found - and they could not - to prevent this equalized wealth from running back again, more or less, into masses, would still leave every body poor, at the same time that it cut up by the roots a great mass of industrious occupations. What is vastly more important than the distribution of the actually accumulated wealth, is the distribution of the annual returns of human industry. But no redistribution even of that - though it might sweep away the existing comfortable class - would suffice, very materially, to elevate the condition of the great body of the people. Above and beyond any of these schemes of redistribution, in order to redeem the mass of the people from poverty and its incidents, a great increase in the amount both of accumulated wealth and of annual products is absolutely essential.

Here, indeed, we discover one great reason of the state of social depression in which the mass of the people have been, and still are, so generally held. 
The good things which the combined efforts of any given community can as yet produce are not enough to give hardly a taste to every body; and the masses have of necessity been kept at hard labor, on bread and water, while luxuries and even comforts have been limited to a few. Labor - the sole resource of the mass of the people - has been of little value, because labor has been able to produce but little; and the proceeds of the labor of production being so small, hence the greater stimulus to substitute in place of it fraud and violence as means of acquisition. The same man who will remorselessly cut your throat in the struggle for the scanty waters of a rivulet in the desert, not enough for the whole thirsty and and gasping company, would readily share his cup with you did the stream only run a little fuller.

The first great necessity, then, of the human race is the increase of the productiveness of human labor. Science has done much in that respect within the last century, and in those to come is destined to do vastly more. Vast new fields are opening on our American continent, on which labor can be profitably employed. So far from labor being the sole source of wealth, all-sufficient in itself, as certain political economists teach, nothing is more certain than that Europe has long suffered, and still suffers, from a plethora of labor - from being obliged to feed and clothe many for whom it has had nothing remunerative to do. The United States of America have now attained to such a development, that they are able easily to absorb from half a million to a million annually of immigrants from Europe. What is more, the laborers of Europe have found it out, and are 
rapidly emigrating. In so doing, not only do they change a barren field of labor for a fertile one, and at the same time relieve the pressure at home, but, by becoming themselves consumers, far more so than ever they were able to be at home, of the more artificial products of the countries from which they emigrate, they contribute doubly to raise the wages of those whom they have left behind.

The development of productive industry seems then to be at this moment one of the greatest and most crying necessities of the human race. But what is more essential to this development than peace and social order? It is not pusillanimity, then, on the part of the people of Europe, but an instinct, more or less conscious, of what they need most, that prompts them to submit for the present, without further struggle, to the rulers who have shown themselves to possess, for the time being, the power to govern - a power, let it be noted, quite too unstable, however, not to require, even in the view of those who possess it, great circumspection and moderation in its exercise. War and civil commotions, though sometimes necessary to the preservation of popular liberties, have very seldom indeed been the means of their acquisition; conspiracies hatched abroad, never. When the fruit is ripe, it will fall almost without shaking the tree. What prompts to anticipate that period is much oftener individual or class suffering or ambition than the true interest of the mass of the people. The greatest obstacle at this moment to the comparative political freedom of Europe, is the vast aggregation of power in the shape of standing armies. But how are these armies possibly to be 
got rid of, except by a certain interval of uninterrupted quiet, dispensing with their use, and such a contemporaneous increase in the value of labor as to make the maintenance in idleness of so many hands, instead of being, as it now is, a sort of substitute for a poor law, and a relief to the overstocked labor market, a useless sacrifice, and an expense too great for any community to submit to?

It surely is not from barricades and street insurrections, provoking the murder of quiet citizens in their own houses, by fusilades and grape shot, in the name of peace and order, but rather from a more careful, comprehensive, and profound study of social relations, joined to an interval of peaceful coöperation in the production of great economical results, that we are to hope for the dispersion and extinction of those un- . fortunate and unfounded antipathies, so rife at present, between those who labor with their heads and those who labor with their hands; those who plan and those who execute - antipathies growing out of prevailing but mistaken theories of politics and political economy, which, by dividing the party of progress into two hostile sections, filled with jealousy, fear, and hatred of each other, have contributed so much more than any thing else to betray Samson, shorn, into the hands of the Philistines - jealousies, fears, and hatreds, not only the chief source of the discomfitures recently experienced by the popular cause, but which, so long as they shall continue, will render any further advancement of it hopeless.

This socialist question of the distribution of wealth once raised is not to be blinked out of sight. The claims set up by the socialists, based as they are upon 
philosophic theories of long standing, having, at least some of them, many ardent supporters even in the ranks of those who denounce the socialists the loudest, cannot be settled by declamations and denunciations, and mutual recriminations, any more than by bayonets and artillery. It is a question for philosophers; and until some solution of it can be reached which both sides shall admit to be conclusive, what the party of progress needs is not action - for which it - is at present disqualified by internal dissensions - but

- deliberation and discussion. The engineers must first bridge this gulf of separation before all the drumming, and fifing, and shouting in the world can again unite the divided column, and put it into effectual motion. 


\section{-}

...

I

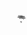


$p^{2}$ 





\section{RETURN}

W A AY IISF

TO

\section{MAIN CIRCULATION}

ALL BOOKS ARE SUBJECT TO RECALL RENEW BOOKS BY CALLING 642-3405

\section{DUE AS STAMPED BELOW}

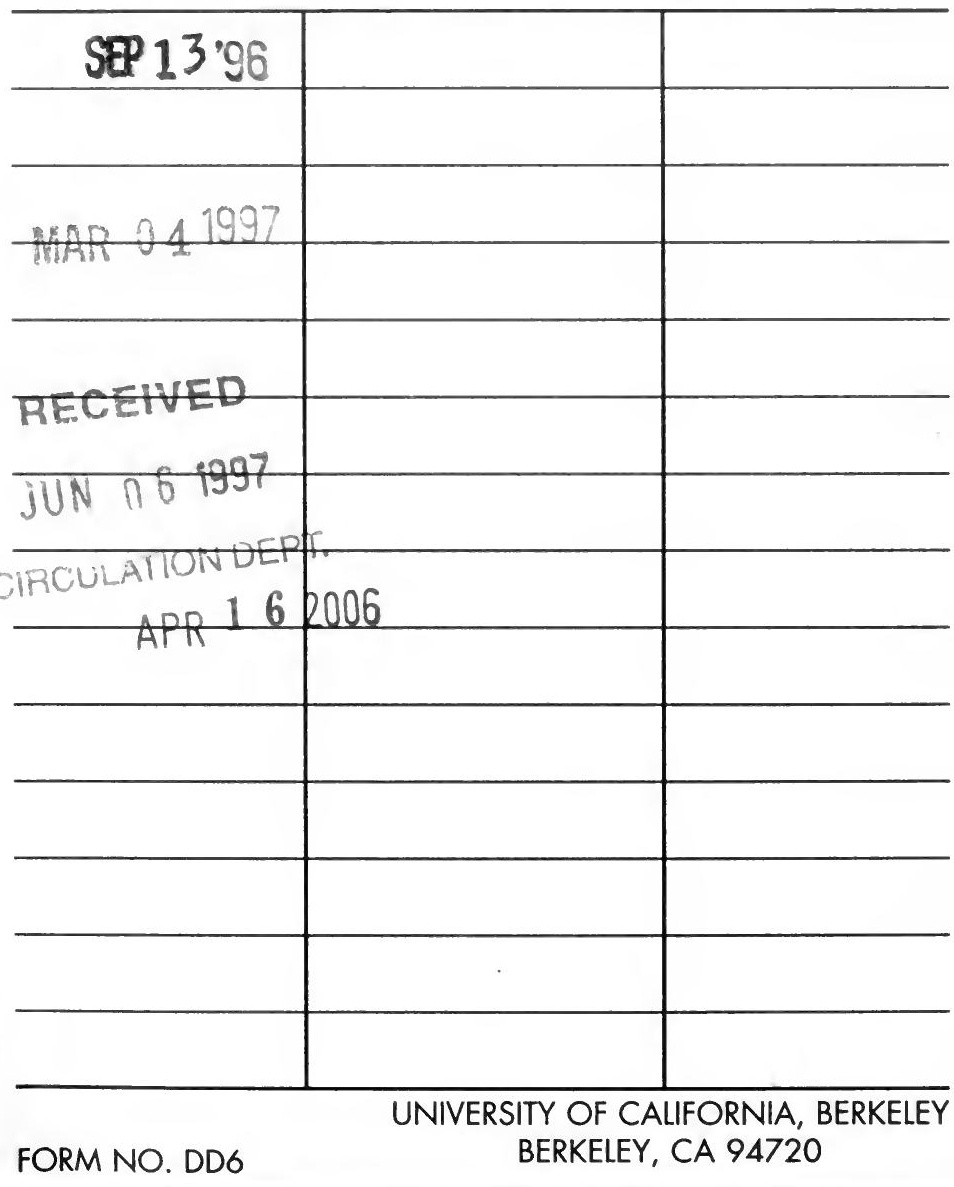




\section{U.C. BERKELEY LIBRARIES}

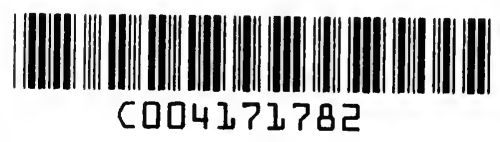

i.

$p 230$

$\because 5 \%$,

$\therefore \div ; 3, \quad 8=$ 
